\title{
Small peptides modulate the immune function of the ion channel-like protein ACD6 in Arabidopsis thaliana
}

Wangsheng Zhu',2*, Lei Li', Benjamin Neuhäuser³, Michael Thelen',6, Mingyu Wang2, Junbin Chen², Luyang Wei², Kavita Venkataramani',7, Moises Exposito-Alonso',8, Chang Liu4,5, Jakob Keck', A. Cristina Barragan', Rebecca Schwab', Ulrich Lutz', Uwe Ludewig³, and Detlef Weigel ${ }^{*}$

'Department of Molecular Biology, Max Planck Institute for Developmental Biology, 72076 Tübingen, Germany

${ }^{2}$ China Key Laboratory of Pest Monitoring and Green Management, MOA, and College of Plant Protection, China Agricultural University, 100193, Beijing, China

${ }^{3}$ Nutritional Crop Physiology, University of Hohenheim, 70599 Stuttgart, Germany ${ }^{4}$ Center for Plant Molecular Biology (ZMBP), University of Tübingen, 72076 Tübingen, Germany 5 Institute of Biology, University of Hohenheim, 70599 Stuttgart, Germany

Current addresses:

6Institute for Physical and Theoretical Chemistry, University Tübingen, 72076 Tübingen, Germany ${ }^{7}$ Department of Biology, University of Massachusetts Boston, Boston, MA 02125, USA 8Department of Plant Biology, Carnegie Institution for Science, Stanford, CA 94305, USA

*Correspondence: zhuws.hzau@gmail.com (W.Z.); weigel@weigelworld.org (D.W.) 
bioRxiv preprint doi: https://doi.org/10.1101/2021.01.25.428077; this version posted January $26,2021$. The copyright holder for this preprint (which was not certified by peer review) is the author/funder, who has granted bioRxiv a license to display the preprint in perpetuity. It is made available under aCC-BY 4.0 International license.

\section{Abstract}

The quantitative resistance gene ACCELERATED CELL DEATH 6 (ACD6), which encodes a transmembrane protein with intracellular ankyrin repeats, has been implicated in a trade-off between growth and defense among wild strains of Arabidopsis thaliana. Naturally hyperactive alleles of the ACD6-Est-I type can lead to spontaneous activation of immune responses, although the extent of visible hyperimmunity in strains with this allele varies substantially. We have identified a natural suppressor locus, MODULATOR OF HYPERACTIVE ACD6 I (MHAI), which codes for a small protein of $\sim 7 \mathrm{kDa}$ that attenuates activity of the ACD6-Est-I allele. MHAI and its paralog MHAI-LIKE (MHAL) differentially interact with specific ACD6 variants, and both MHAI and MHAL peptides can bind to the ACD6 ankyrin repeats. MHAL also enhances accumulation of an ACD6 complex, thereby increasing activity of the ACD6 standard allele. The ACD6 ankyrin repeats are similar to those of transient receptor potential (TRP) ion channels, and several lines of evidence support that increased ACD6 activity is linked to enhanced calcium signaling. Our work highlights how the study of natural variation reveals new aspects of plant immunity.

\section{Introduction}

While plants need to defend themselves against pathogens, an inherent danger is inappropriate activation of immune responses, which can cause collateral damage to the plant itself. Particularly effective immune alleles enable a plant to respond rapidly to pathogen attack, but such variants might also be potentially deleterious. The study of natural variation in the immune system of Arabidopsis thaliana has identified ACCELERATED CELL DEATH 6 (ACD6) as a nexus for a trade-off between growth and disease resistance in wild populations (Świadek et al., 2016; Todesco et al., 2014, 2010). ACD6 is a positive regulator of cell death and defense responses and the EMS-induced acd6-I gain-of-function allele has constitutively elevated defenses and a prominent lesion-mimic phenotype (Lu et al., 2003). Similar to acd6-I, the naturally hyperactive ACD6-Est-I allele can protect plants against a wide range of unrelated pathogens, but at the same time often exacts a substantial growth penalty in form of reduced stature and leaf necrosis (Todesco et al., 2010). The same is true for the natural hybrid necrosis alleles ACD6-Mir-0 and ACD6-Se-0 (Todesco et al., 2014).

The hyperimmunity conditioned by increased ACD6 activity is dependent on salicylic acid (SA), with inactivation of individual SA signaling components, such as NON-EXPRESSOR OF PRI (NPRI), ENHANCED DISEASE SUSCEPTIBILITY I (EDSI) and PHYTOALEXIN DEFICIENT 4 (PAD4), partially suppressing the effects of ACD6 hyperactivity ( $\mathrm{Ng}$ et al., 20I I; Rate et al., 1999). SA signaling is required for several aspects of plant immunity, including pattern- and effector-triggered immunity (PTI and ETI) as well as systemic acquired resistance (SAR) (Fu and Dong, 2013; Lu et al., 2016; Seyfferth and Tsuda, 2014; Vlot et al., 2009). Both SA biosynthesis and many aspects of SA up- and downstream signaling are well understood, with feedback and feedforward regulation being important mechanisms. A complex of EDSI and PAD4 functions downstream of nucleotide binding site/leucine rich repeat receptors (NLRs) with an N-terminal Toll/interleukin-I receptor/resistance protein (TIR) domain to activate SA biosynthesis, and the accumulating SA further enhances EDSI and PAD4 expression. Similarly, ACD6 stimulates SA accumulation, and SA in turn enhances 
bioRxiv preprint doi: https://doi.org/10.1101/2021.01.25.428077; this version posted January 26, 2021. The copyright holder for this preprint (which was not certified by peer review) is the author/funder, who has granted bioRxiv a license to display the preprint in perpetuity. It is made available under aCC-BY 4.0 International license.

ACD6 mRNA expression and affects the subcellular localization of ACD6 protein (Lu et al., 2003; Zhang et al., 20I4). A working model for ACD6 is that it is a redundant key regulator of SA signaling through a positive SA-dependent feedback loop (Lu et al., 2003; Tateda et al., 20I4; Zhang et al., 20I4). While its exact relationship to PTI, ETI and SAR is not entirely clear, it interacts genetically with an allele of the TIR-NLR gene SUPPRESSOR OF NPRI-I, CONSTITUTIVE I (SNCI) (Zhu et al., 20I8).

ACD6 encodes a multipass transmembrane protein with nine intracellular ankyrin repeats (Lu et al., 2003; Zhang et al., 2014). ACD6 protein has been found in association with multiple plasma membrane localized pattern recognition receptors (PRRs) and the PRR co-receptor BRII-ASSOCIATED RECEPTOR KINASE I (BAKI), as well as other receptor like kinases, supporting a direct role for ACD6 in plant immunity (Tateda et al., 20I4; Zhang et al., 20I7, 20I4). In response to SA signalling, ACD6 oligomers accumulate at the plasma membrane, indicating that plasma membrane localisation of ACD6 is important for its function (Tateda et al., 20l4; Zhang et al., 2014). Another ankyrin-repeat transmembrane protein, BDAI, also functions as a positive regulator of immunity in A. thaliana (Yang et al., 2012), and a maize ACD6 homolog has recently been implicated in smut resistance (Zhang et al., 2019). However, the precise biochemical mechanism by which ACD6 and related proteins act remains enigmatic.

An important theme in plant immunity is that many immune system components can interact in a non-additive manner (Kover and Caicedo, 200I). Epistatic interactions are common in the regulatory and structural gene networks underlying the biosynthesis of plant metabolites, including many metabolites important for defense against pathogens (Soltis and Kliebenstein, 20I5). In NLR-mediated disease resistance, different alleles and orthologs of the powdery mildew resistance NLR gene Pm3 in cereals can interfere with each other's activity (Hurni et al., 2014; Stirnweis et al., 2014). Conversely, there are highly redundant NLR networks of protein-protein interactions in several species (Wróblewski et al., 2018; Wu et al., 2017), and inappropriate interaction among NLRs or between NLRs and other proteins can lead to adverse outcomes in the form of autoimmunity (Li et al., 2020; Tran et al., 2017).

That not all ACD6-Est-I carriers express autoimmunity suggests, however, that the detrimental effects of ACD6-Est-I are often mitigated by second-site modifiers (Todesco et al., 20I0; Zhu et al., 20I8). Here, from the epistatic interaction of $A C D 6$ with natural alleles present at an unlinked locus, we identify a new gene family encoding small peptides, MODIFIER OF HYPERACTIVE ACD6 I (MHAI) and its paralog MHA-LIKE (MHAL), which modulate the activity of ACD6 in a complex manner. Consistent with sequence similarity of ankyrin repeats in ACD6 with those of transient receptor protein (TRP) ion channels from animals and fungi, we find that increased ACD6 activity enhances calcium signaling, either by modulating activity of other ion channels or by ACD6 acting itself as ion channel. Since MHAI and MHAL both bind to the ankyrin repeats of ACD6 and affect ACD6 activity, we propose that MHAI and MHAL are ACD6 ligands. 


\section{Results}

\section{Identification of MODIFIER OF HYPERACTIVE ACD6 (MHA) loci}

We have previously reported that many, but not all $A$. thaliana accessions carrying the ACD6-Est-I allele express leaf necrosis in the absence of pathogen challenge (Todesco et al., 2010). In several cases, genetic mapping showed that this is due to second site modifiers, with different accessions containing different modifiers (Zhu et al., 2018). Because appreciable population frequency might indicate that an allele has been favored by selection, we were particularly interested in modifiers that are shared by a larger number of accessions. We reasoned that it should be possible to detect such common loci by genome-wide association (GWA) analysis of necrosis severity among accessions with the ACD6-Est-I allele. We first identified such a set through a combination of Sanger sequencing and perusal of short-read data from the $100 \mathrm{I}$ Genomes Project (100I Genomes Consortium, 2016; Zhu et al., 2018), and scored necrosis on an arbitrary scale in 84 accessions (Table I). Using the EMMAX algorithm (Grimm et al., 2016), we identified two unlinked regions with significant associations, MODIFIER OF HYPERACTIVE ACD6 I (MHAI) (Chrl: 22,935,037, p=I012), and MHA2 (Chr4: II,019,243, p=10-8) (Figure IA), which together explained over 60\% of phenotypic variation.

The most highly associated SNP at MHA2 is in an intron of SBT2.2/AT4G20430 (Figure I-figure supplement IA), predicted to encode an extracellular subtilisin-like protease, possibly involved in the regulation of cell death (Ramírez et al., 20I3; Schaller et al., 2018). The top SNP at MHAI causes a nonsynonymous substitution in ATI G62045, which encodes a small protein without domains of known function (Figure I-figure supplement IB). At both loci, attenuated ACD6-Est-I dependent necrosis was associated with the minor alleles, found in 17 and 29 accessions, respectively (Figure I B).

The frequencies of the MHAI and MHA2 alleles were similar in the 87 ACD6-Est-I accessions (of which 84 had been used for GWA) and in the 797 accessions with other ACD6 alleles from the I00I Genomes project (100I Genomes Consortium, 2016). However, we observed that among the ACD6-Est-I GWA accesions, accessions with the MHA2-Ty-0 allele were about twice as likely to have the MHAI-Ty-0 allele (12/19) than accessions with the standard MHA2 allele (17/65) (Figure I-figure supplement 2A). Accordingly, the average linkage disequilibrium between the causal SNP from MHAI (Chrl: 22935037) and SNPs across the entire MHA2 locus was much higher in the ACD6-Est-I population used for GWA than in the non-ACD6-Est-I set of accessions ( $p<0.000 \mathrm{I}$, Wilcoxon nonparametric test) (Figure I-figure supplement 2B). Haplotype analysis further revealed that the only allele combination that was enriched in the two populations with and without the ACD6-Est-I allele was the combination of both Ty-0-type suppressor alleles at MHAI and MHA2 in accessions with the ACD6-Est-I allele ( $p=0.006$, binomial test) (Figure I-figure supplement $2 \mathrm{C}$ ). These results suggest that greater suppression of ACD6-Est-I effects is favorable in natural populations.

To confirm linkage of the GWA hits to suppression of ACD6-Est-I induced necrosis, we made use of the accession Ty-0, which has minor alleles at both MHAI and MHA2 (Figure IC). There were no nonsynonymous differences in ACD6 between Ty-0 and Est-I (Table 2), and ACD6 was well expressed, 
bioRxiv preprint doi: https://doi.org/10.1101/2021.01.25.428077; this version posted January 26, 2021. The copyright holder for this preprint (which was not certified by peer review) is the author/funder, who has granted bioRxiv a license to display the preprint in perpetuity. It is made available under aCC-BY 4.0 International license.

although not quite as highly as in Est-I (Figure ID). Ty-0 had much less salicylic acid (SA) than Est-I, and reduced expression of the SA-responsive marker gene PATHOGENESIS-RELATED I (PRI) (Figure ID, E). As expected, ACD6-Ty-0 and ACD6-Est-I similarly triggered necrotic lesions and reduced biomass when introduced as transgenes into the Col-0 background (Figure IF, G). Together, these results demonstrate that Ty-0 harbors extragenic suppressors that mask the effects of ACD6-Est-I.

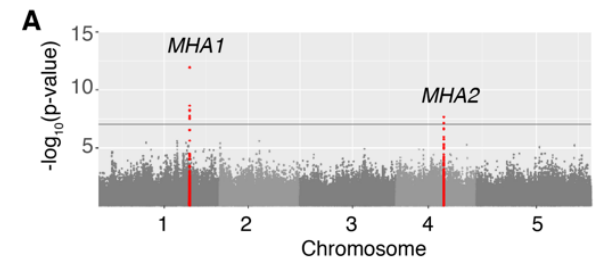

C

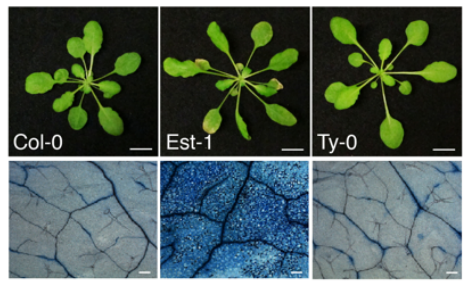

D

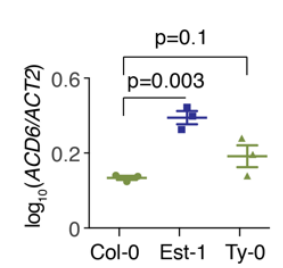

G

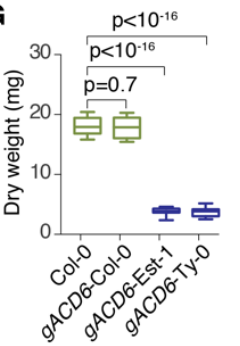

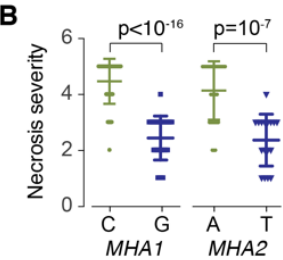

E

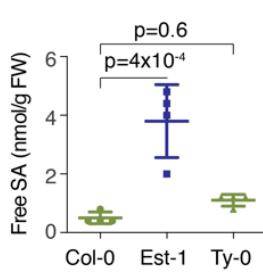

$\mathbf{F}$

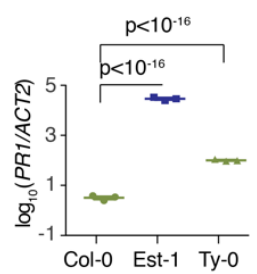

H

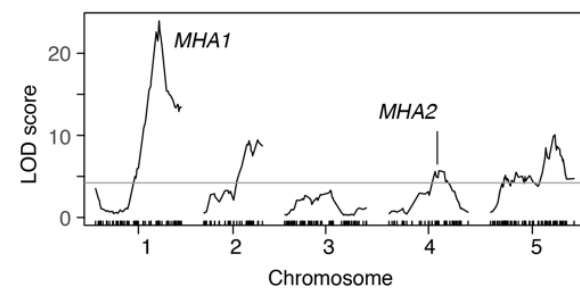

Figure I. Genetic background dependence of ACD6-Est- I effects. (A) Manhattan plot of GWA scores for necrosis. SNPs within $60 \mathrm{~kb}$ of the top SNPs in red. The horizontal gray line indicates a nominal $\mathrm{p}=0.05$ threshold after Bonferroni correction. (B) Necrosis score of accessions with different MHAI and MHA2 alleles. (C) Top, four-week-old plants with different ACD6 alleles. Bottom, Trypan Blue-stained sixth leaves. Scale bars, I cm (top), $0.2 \mathrm{~mm}$ (bottom). (D) ACD6 and PRI expression, as measured by RTqPCR from three biological replicates each. (E) Accumulation of free salicylic acid (SA) in different genotypes. (F) Eighteen-day old transgenic lines in Col-0 background in $23^{\circ} \mathrm{C}$ LD. Scale bar, I cm. (G) Dry weight of 3-week-old plants. (H) QTL map of necrosis in Ty-O $\times$ Est-I $F_{2}$ population. Black line, significance threshold of $p=0.05$ from 1,000 permutations. p-values (B, D, E, G) from Tukey's HSD test.

Since the ACD6 alleles of Ty-0 and Est-I had similar activity, a Ty-0 $x$ Est-I $F_{2}$ population provided a straightforward tool for direct mapping of genomic regions associated with suppression of ACD6-Est-I induced necrosis.

Linkage analysis identified four QTL in this cross, with none of the QTL including ACD6 itself, as expected (Figure IH, Figure I-figure supplement 3A, B). The GWA hit MHA2 was included in the confidence interval of a QTL on chromosome 4 that explained $9 \%$ of phenotypic variation. Overexpression of the major allele of SBT2.2 triggered ACD6-dependent spotted cell death in the Col-0 background at $16^{\circ} \mathrm{C}$ that was accompanied by increased expression of $P R I$ (Figure I-figure supplement 4). This observation provides evidence for a functional link between MHA2/SBT2.2 and ACD6 activity.

\section{MHAI and its paralog MHAL define a new gene family encoding small proteins}

The SNP with the highest QTL LOD score, at the locus that explained about $40 \%$ of the necrosis variation in the Ty- 0 x Est-I $F_{2}$ population, was within $50 \mathrm{~kb}$ of the best genome-wide GWA hit, in MHA I (Figure ID). We established Heterogeneous Inbred Families (HIFs) (Loudet et al., 2005) and found that among $F_{3}$ and $F_{6}$ descendants with reduced or no leaf necrosis, the MHAI-Est-I allele was highly underrepresented (Figure I-figure supplement 3C). A Near-Isogenic Line (NIL) with the MHA I-Est-I allele was smaller 
bioRxiv preprint doi: https://doi.org/10.1101/2021.01.25.428077; this version posted January 26, 2021. The copyright holder for this preprint (which was not certified by peer review) is the author/funder, who has granted bioRxiv a license to display the preprint in perpetuity. It is made available under aCC-BY 4.0 International license.

and suffered from more necrosis than the corresponding NIL with the Ty-0 allele (Figure 2A). Pseudomonas syringae pv. tomato (Pst) DC3000 expressing avrRpt2 has been shown before to respond to differences in ACD6 activity (Lu et al., 2003), and Pst DC3000 avrRpt2 grew to lower levels in the NIL with the Est-I allele, consistent with MHAI-Ty-0 suppressing the immunity-enhancing activity of ACD6-Est-I (Figure 2B). Two HIFs allowed us to narrow the QTL interval to a $200 \mathrm{~kb}$ region from 22.83 and 23.03 Mb (Figure I-figure supplement 3D). In the center of this region, at $22.94 \mathrm{Mb}$, was our top GWA hit, ATIG62045, which encodes a small $\sim 7$ kDa protein of 67 amino acids.
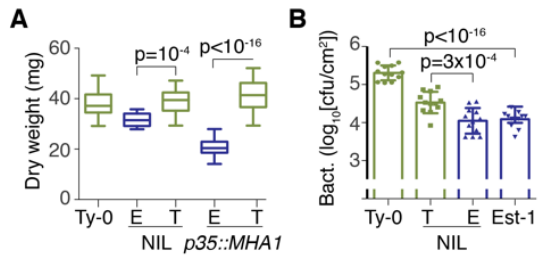

E

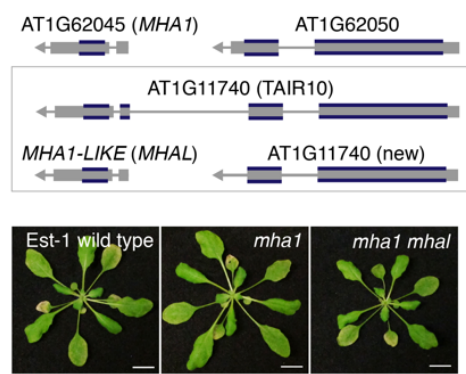

C

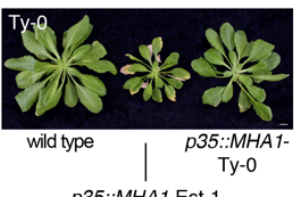

p35::MHA1-Est-1

G

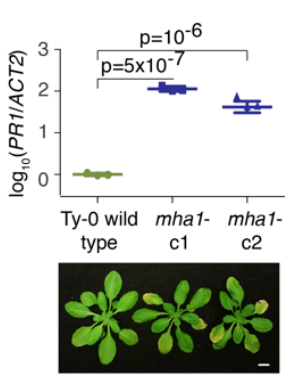

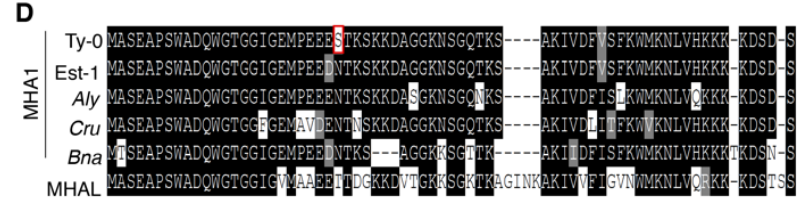

H

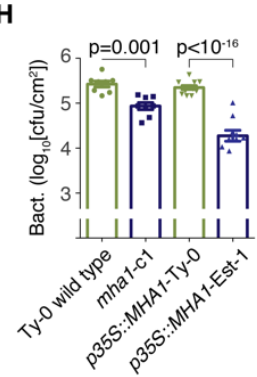

I

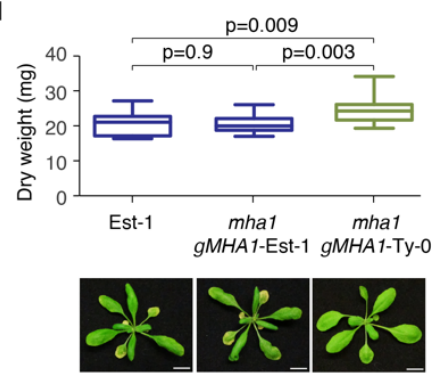

Figure 2. Identification of MHAI as a genetic modifier of ACD6-Est-I. (A) Dry weight of 4-week-old plants with different MHAI alleles. E, Est-I; T, Ty-0. (B) Growth of Pst DC3000 avrRpt2 three days after infection. Four-week old NILs with the MHAI-Ty-0 allele support more Pst DC3000 avrRpt2 growth than those with the Est-I allele. (C) Five-week old p35S::MHAI transgenic lines in Ty-0 background grown in $23^{\circ} \mathrm{C}$ SD. Left, non-transgenic control. Scale bar, I cm. (D) MHAI protein alignment among Brassicaceae (Aly, Arabidopsis lyrata; Cru, Capsella rubella; Bna, Brassica napus). MHAI-Ty-0-specific polymorphism highlighted in red. (E) Correction of gene annotation of MHAILIKE (MHAL) in the A. thaliana reference genome. Paralogous MHAI region shown on top. (F) CRISPR/Cas9 induced mhal and mhal mhal mutants in Est-I background. (G) Top: Accumulation of PRI mRNA, as measured by RT-qPCR from three biological replicates each in Ty-0 mhal mutants. Bottom: Plant phenotypes. Scale bar, I cm. (H) Growth of Pst DC3000 avrRpt2 three days after infection. In the Ty-0 background, overexpression of the MHAI-Est-I allele, but not of the MHAI-Ty-0 allele, reduces DC3000 avrRpt2 growth, similar to inactivation of mhal in this background. (I) Transgenic Est-I mhal mutants containing genomic MHAI fragments from Est-I or Ty-0. Top, Leaf biomass of 4-weekold plants. $p$-values from Tukey's HSD test. Bottom: Plant phenotypes. Scale bar, I cm.

To directly confirm that MHAI could suppress ACD6-Est-I activity, we overexpressed in the Ty-0 background the MHAI alleles of Ty-O and Est-I, which differ in two adjacent codons, with one of these causing a non-conservative change from asparagine to serine due to the top GWA SNP. Overexpression of MHAI-Ty-0 had no apparent effects on plant morphology (2I TI plants), while MHAI-Est-I caused strong leaf necrosis and reduced size in 13 out of $15 T_{1}$ individuals (Figure 2C). These results not only supported the identification of ATIG62045 as MHAI, but also suggested that activity of the MHAI-Ty-O allele is compromised relative to the MHAI-Est-I allele. MHAI homologs are found in many dicotyledonous plant species, and alignment of the predicted protein sequences told us that other Brassicaceae typically encode the asparagine corresponding to the Est-I variant, which is representative of the major A. thaliana allele (Figure 2D). Finally, because $A C D 6$ is an immunity regulator, we wondered whether there was any 
bioRxiv preprint doi: https://doi.org/10.1101/2021.01.25.428077; this version posted January $26,2021$. The copyright holder for this preprint (which was not certified by peer review) is the author/funder, who has granted bioRxiv a license to display the preprint in perpetuity. It is made available under aCC-BY 4.0 International license.

evidence for its genetic interactor MHAI having a role in defense. Consultation of an expression atlas (Winter et al., 2007) revealed that MHAI expression was elevated when plants are infected with the bacterium Pst DC3000 expressing avrRpm I or with the fungus Botrytis cinerea.

In the A. thaliana reference genome, MHAI and the adjacent gene ATIG62050 are paralogous to the 3' and 5' portions of another gene on chromosome I, ATIGII740. This gene model appears to be misannotated, as public RNA-seq data and RT-PCR analyses indicated that the gene model erroneously fuses two independent genes that are paralogs of MHAI and ATIG62050, respectively (Figure 2E, Figure 2figure supplement IA-D). We named the MHAI paralog MHA I-LIKE (MHAL).

\section{Genetic characterization of the MHAI paralog MHAL}

To determine the function of MHAI and its paralog MHAL in regulating ACD6 activity, we used CRISPR/Cas9 genome editing (Wu et al., 2018) to mutate both genes in Est-I, which has the hyperactive ACD6 allele. Both mhal and mhal mhal double mutants continued to show typical ACD6-Est-I-induced necrosis, suggesting that MHAI and MHAL do not simply act downstream of ACD6 (Figure 2F, Figure 2-figure supplement IE,F).

Surprisingly, even though the Ty-O allele of MHAI carried a nonsynonymous substitution that affected a conserved asparagine (Figure 2D), consistent with this allele having reduced or no activity, its inactivation led to leaf necrosis and greatly increased PRI expression in Ty-0 (Figure 2G). This was surprising because similar effects were seen when we overexpressed MHAI-Est-I in Ty-0 (Figure 2C,H), suggesting that the Est-I allele, rather than the Ty-0 allele, was the functional allele. Introduction of a genomic copy of MHAI-Ty-0 into Est-I mhal mutants suppressed leaf necrosis and increased biomass, in agreement with this allele interfering with the action of ACD6-Est-I (Figure 21). Together, these data pointed to MHA I-Ty- 0 as a gain-of-function allele that acts as a negative regulator of ACD6-Est-I activity in both necrosis and pathogen protection, with the standard allele, MHAI-Est-I, masking the action of MHAI-Ty-0, even though MHA I-Est-I is not required for ACD6-Est-I activity. Overexpression of either MHAI-Ty-0 or MHA IEst-I did not have obvious effects in a Col-0 background, nor did it appear to modify the phenotype of the laboratory-induced acd6-I gain-of-function allele.

The unusual relationship between the Ty- 0 and Est-I alleles suggested that the functional interaction between MHAI and ACD6 is perhaps complicated by the presence of the MHAL paralog, even though the absence of a clear effect on ACD6-Est-I activity in the mhal mhal double mutant had not pointed to MHAI and MHAL being simply redundant. To gain first insights into MHAL function, we compared the effects of overexpressing MHAI and MHAL in the reference accession Col-0, which has the standard ACD6 allele, which does not cause necrosis. Neither MHA I-Est-I nor MHAI-Ty-0 overexpression had obvious effects in Col-0, although the MHA I-Est-I slightly increased expression of PRI (Figure 3A). In contrast, overexpression of MHAL, which does not show allelic variation in amino acid sequence between Col-0, Est-I and Ty-0, caused strong necrosis and dwarfing at $16^{\circ} \mathrm{C}$ in 24 out of $30 \mathrm{~T}$ । plants (Figure 3B). The effects at $23^{\circ} \mathrm{C}$ were milder (Figure 3-figure supplement IA), which can be at least partially attributed to reduced accumulation of the protein at the higher temperature, as demonstrated with plants overexpressing an 
bioRxiv preprint doi: https://doi.org/10.1101/2021.01.25.428077; this version posted January $26,2021$. The copyright holder for this preprint (which was not certified by peer review) is the author/funder, who has granted bioRxiv a license to display the preprint in perpetuity. It is made available under aCC-BY 4.0 International license.

Zhu et al.

Regulation of ACD6 ion channel-like protein by small peptides

MHAL-GFP fusion (Figure 3-figure supplement IB). The temperature sensitivity of the MHAL overexpressors suggested that MHAL can enhance ACD6 activity, since it resembled the behavior of acd6-I gain-of-function mutants, which also show enhanced necrosis at $16^{\circ} \mathrm{C}$ compared to the standard temperature of $23^{\circ} \mathrm{C}$ (Figure 3B, Figure 3-figure supplement IA) (Todesco et al., 20I4).

Since ACD6 is both a regulator and effector of SA responses (Lu et al., 2003; Rate et al., 1999; Tateda et al., 2014; Zhang et al., 2014), we were interested in the relationship between ACD6 and the EDSI/NRGI/ADRI node of lipase-like proteins and so-called helper NLRs (hNLRs), a convergence point of both ETI and PTI signaling that controls both SA-dependent and -independent defenses (Cui et al., 2017; Lapin et al., 2020; Pruitt et al., 2020; Sun et al., 2020; Wu et al., 2019). To test the requirement of hNLRs for MHAL activity, we overexpressed MHAL in plants carrying different combinations of mutations in the $A D R I$ and NRGI subfamilies of hNLRs (Wu et al., 2019). MHAL-induced necrosis and dwarfism were partially suppressed in $\mathrm{nrg} /$ triple mutants and fully suppressed in $\mathrm{adr} / \mathrm{nrg} /$ sextuple mutants (Figure 3C), indicating that $\mathrm{hNLRs}$ are redundantly required for MHAL function. While the redundancy between the two subfamilies was in agreement with other findings (Lapin et al., 2020; Pruitt et al., 2020; Sun et al., 2020; Wu et al., 2019), the stronger suppression of the MHAL overexpression effects was somewhat surprising, since it is the ADRI subfamily that has been primarily linked to SA signaling (Bonardi et al., 20I I; Castel et al., 2019). Additional genetic analysis confirmed that MHAL overexpression defects were dependent on SA accumulation, as the phenotype was completely suppressed by expression of the bacterial salicylate hydroxylase gene bacterial nahG gene, which converts SA to catechol (Gaffney et al., 1993), similar to what has been reported for other lines with increased ACD6 activity (Lu et al., 2005, 2003; Rate et al., 1999; Todesco et al., 2014, 2010) (Figure 3-figure supplement 2). Mutations in NPRI, which partially attenuates SA signaling, had more modest effects on the phenotype of MHAL overexpressors, similarly to what has been reported for acd6-I mutants (Rate et al., 1999) (Figure 3-figure supplement 2).

To test the genetic requirements for the semi-lethal effects of MHAL overexpression in an unbiased manner, we mutagenized MHAL overexpressors in the Col-0 background with ethyl methanesulfonate. When we sequenced the genomes of $72 M_{3}$ suppressor of MHAL (somhal) lines, we found multiple mutations in RSTI and mutations XRN4, two loci that prevent transgene silencing (Gazzani et al., 2004; Lange et al., 2019; Li et al., 2019) (Table 3). The most often mutated locus was ACD6, in 37 of the 72 suppressor lines, with 28 distinct variants (Figure 3D, Table 3). Four mutations in ACD6 caused non-synonymous substitutions that have been reported as intragenic suppressors of the acd6-I gain-of-function allele (Lu et al., 2005), consistent with them being loss-of-function alleles. We confirmed that the ACD6 locus co-segregated with suppression of MHAL-associated necrosis for one of the mutant lines (Figure 3E). In somhal lines without mutations in $A C D 6$, strong necrosis was restored in $F_{1}$ progeny from a cross to the acd6-2 loss-of-function mutant, indicating that the transgene itself was not mutated and that the suppressor mutations were apparently at other loci (Figure 3F). Final validation for ACD6 being essential for the effects of MHAL overexpression was obtained with the known acd6-2 loss-of-function allele, which suppressed the MHAL overexpression phenotype as well (25 $T_{1}$ individuals) (Figure 3G, Figure 3-figure supplement 3A). In contrast, the acd6-I gain-of-function mutation greatly enhanced the phenotype of MHAL overexpressors 
bioRxiv preprint doi: https://doi.org/10.1101/2021.01.25.428077; this version posted January 26, 2021. The copyright holder for this preprint (which was not certified by peer review) is the author/funder, who has granted bioRxiv a license to display the preprint in perpetuity. It is made available under aCC-BY 4.0 International license.

( $15 \mathrm{~T}_{1}$ individuals). At $23^{\circ} \mathrm{C}$, acd6-I p35S::MHAL plants resembled MHAL overexpressors without the acd6I allele grown at $16^{\circ} \mathrm{C}$ (Figure 3G, Figure 3-figure supplement 3A).

A

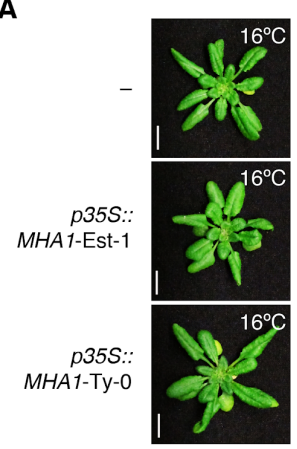

C

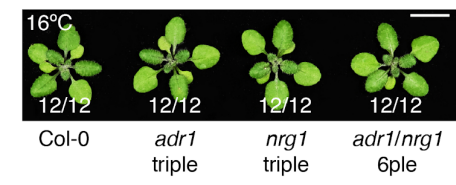

D

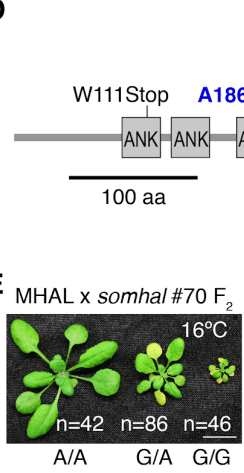

$\mathbf{F}$

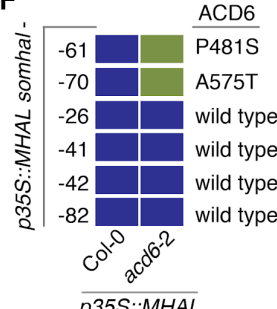

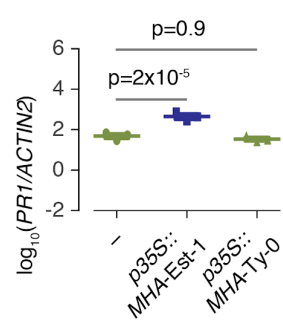

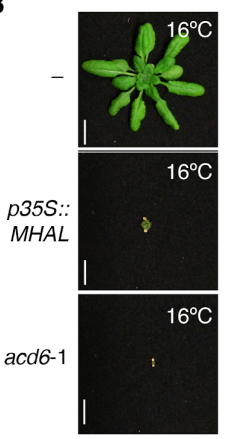

Figure 3. Functional divergence of MHAI and MHAL in causing ACD6-dependent necrosis. (A) Transgenic plants overexpressing MHAI-Est-I or MHAI-Ty-0 alleles in the Col-0 reference background, and accumulation of $P R I$ mRNA, as measured by qRT-PCR from three biological replicates each. $p$-values from Tukey's HSD test. (B) Transgenic plants overexpressing MHAL in Col-0. acd6-I shown for comparison. (C) Effects of mutating hNLR genes in Col-0 or MHAL overexpressors. Numbers indicate fractions of $T_{1}$ transgenic plants with the phenotype shown. (D) Map of 28 EMS-induced somhal mutations in ACD6 identified as suppressors of MHAL-induced necrosis. Numbers indicate codons. Four mutations in bold are identical to ones that have been isolated before as intragenic suppressors of the acd6-I gain-of function allele (Lu et al., 2005). Blue residues are identical in two out of three mammalian TRP proteins (TRPAI, NOMPC, TRPV6), magenta residue in all three. Ankyrin repeats (ANK) annotated; predicted transmembrane helices shown as black boxes. (E) Co-segregation between the polymorphism in acd6 ${ }^{575}$ with p35S:: MHALassociated necrosis in a backcross $F_{2}$ population derived from somhal suppressor mutant \#70 and the parental p355::MHAL line. "A" corresponds to the ACD6 wild-type allele. (F) Phenotypes of $F_{1}$ progeny from crosses of different somhal p35S::MHAL plants to Col-0 p35S:::MHAL and acd6-2 p35S:::MHAL plants. Dark green indicates absence of necrosis (no complementation of somhal p35S::MHAL phenotype), and dark blue necrosis (complementation). ACD6 amino acid changes shown on the right. (G)

Transgenic acd6-2 and acd6-I plants overexpressing MHAL, and accumulation of PRI mRNA, as measured by qRT-PCR from three biological replicates each. $p$-values from Tukey's HSD test. Scale bars, I cm (A, B, E, G), or $0.5 \mathrm{~cm}(C)$.

Together, the experiments with MHAL overexpressors and acd6 loss- and gain-of-function alleles in the Col-0 background indicated that MHAL and ACD6 depend on each other's activities. This conclusion seemed, however, inconsistent with the finding that the hyperactive ACD6-Est-I allele appeared to function in an MHAL-independent manner, since the inactivation of MHAL (and MHAI) did not suppress the ACD6Est-I phenotype (Figure 2B). We confirmed the mutual independence by overexpressing MHAL in an ACD6-Est-I background. Not only was the ACD6-Est-I phenotype not enhanced by MHAL overexpression, but the severe MHAL overexpression phenotype at $16^{\circ} \mathrm{C}$ was suppressed in Est-I and a NIL with the ACD6Est-I allele (Figure 3-figure supplement 3B), indicating genetic interaction of MHAL with the standard ACD6-Col-0, but not the ACD6-Est-I allele. Note that the phenotype of ACD6-Est-I, in contrast to that of acd6-I, is not enhanced by lower temperature (Todesco et al., 20I4, 20I0), which distinguishes ACD6-Est-I 
bioRxiv preprint doi: https://doi.org/10.1101/2021.01.25.428077; this version posted January $26,2021$. The copyright holder for this preprint (which was not certified by peer review) is the author/funder, who has granted bioRxiv a license to display the preprint in perpetuity. It is made available under aCC-BY 4.0 International license.

from many other autoimmunity mutants (van Wersch et al., 2016). These observations were further complicated by the finding that $M H A I$ in the Ty- 0 background suppresses ACD6-Est-I activity, indicating that ACD6-Est-I does not act independently of MHAI. On the other hand, not only did GFP-MHAL accumulate to higher levels in p35S::GFP-MHAL plants at lower temperature (Figure 3-figure supplement IB), but MHAL RNA expression in acd6-I was also enhanced at lower temperature. In addition, GFP-MHAL accumulated to higher levels in an acd6-I background (Figure 3-figure supplement IC). Together, these observations provide a potential explanation for the more severe acd6-I phenotype under lower temperature (Figure 3-figure supplement IA).

\section{Characterization of MHAI and MHAL proteins}

To begin to find possible explanations for the puzzling complexity in genetic interactions between ACD6, MHAI and MHAL, we began to characterize protein-protein interactions. Split-luciferase complementation assays in Nicotiana benthamiana indicated that ACD6-Est-I protein can interact with both MHAI and MHAL (Figure 4A). Co-immunoprecipitation (co-IP) with material extracted from protoplasts overexpressing tagged proteins indicated that ACD6-Col-0 interacts with both MHAL than with MHAI (Figure 4B). ACD6 encodes a transmembrane protein with ankyrin repeats (Lu et al., 2003; Zhang et al., 20I4), which are obvious candidates for the interaction of ACD6 with other proteins. We therefore tested whether MHAL and ACD6-Col-0 might directly bind to each other using in vitro GST pull-down assays. We did detect such binding (Figure 4C), in agreement with the protoplast co-IP results (Figure 4B). In all three assays, splitluciferase, GS pull-down and co-IP, MHAL tended to produce a stronger signal than MHAI, but more quantitative methods will be required to determine whether these apparent differences are significant. Finally, we examined the subcellular localisation of a GFP fusion to MHAI-Est-I in Ty-0. In root cells, GFP signal was found both in the cytoplasm and at the membrane (Figure 4D). After plants had been treated for 45 minutes with $10 \mu \mathrm{M}$ brefeldin $\mathrm{A}$ (BFA), an endocytosis inhibitor, MHAI-GFP accumulated in BFA bodies that co-stained with the endocytic tracer FM4-64, which suggested that MHAI-GFP recycles between the plasma membrane and endosomal compartments, similar to many other plant plasma-membrane proteins (Contento and Bassham, 20I2) (Figure 4E). Subcellular fractionation indicated that both MHAI-GFP and MHAL-GFP proteins were enriched in microsomes (Figure 4F,G), similar to ACD6-I protein (Zhang et al., 20I4) (Figure 4H). The similar subcellular localization of MHAI and ACD6 was in agreement with direct interaction of the proteins.

Given the differential interaction of MHAI and MHAL proteins with ACD6 ankyrin repeats, and the observed genetic interactions, in which MHAL overexpression did not affect ACD6-Est-I activity, while MHAI-Ty-0 suppressed ACD6-Est-I effects, we developed the following hypothesis for the MHAI/MHAL interaction with ACD6: First, MHAL enhances activity of the standard form of ACD6 (as found in Col-0); such an enhanced activity could provide additional feedforward regulation of ACD6 in response to pathogen challenge, as both enhanced ACD6 activity and treatment of plants with a bacterial pathogen increased MHAL mRNA accumulation (Figure 3-figure supplement IE). Second, the amino acid replacements in the transmembrane portion of ACD6-Est-I that are causal for its increased activity (Todesco et al., 2010) alter 
bioRxiv preprint doi: https://doi.org/10.1101/2021.01.25.428077; this version posted January $26,2021$. The copyright holder for this preprint (which was not certified by peer review) is the author/funder, who has granted bioRxiv a license to display the preprint in perpetuity. It is made available under aCC-BY 4.0 International license.

the conformation of ACD6-Est-I, such that it no longer requires binding of MHAL to its ankyrin repeats for increased activity. ACD6-Est-I can, however, be bound by MHAI-Ty-0 (Figure 4A), which in turn interferes with ACD6-Est-I activity.

A

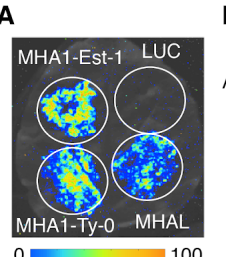

D

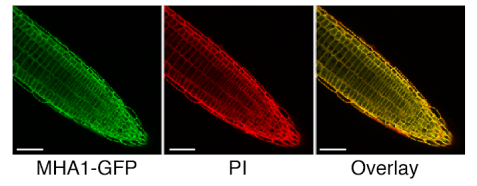

C

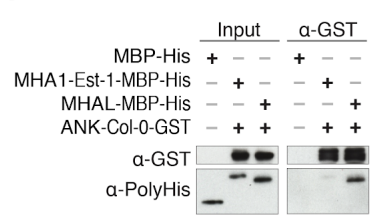

E

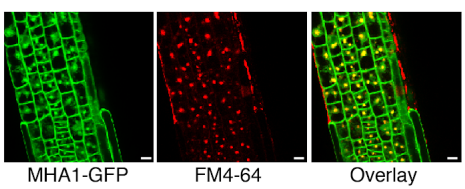

$\mathbf{F}$

G
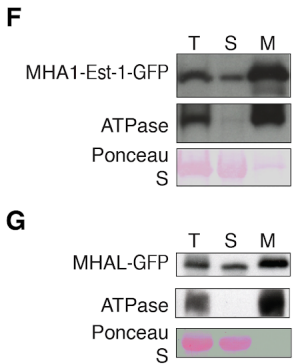

H

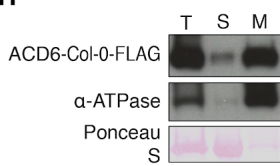

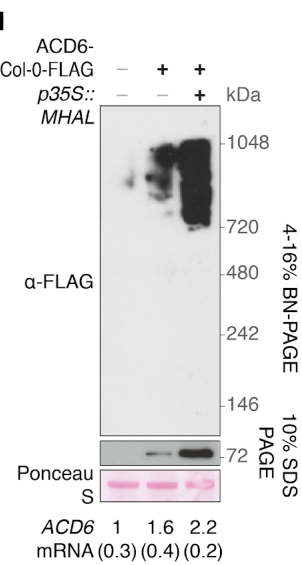

Figure 4. MHAL enhances ACD6 accumulation and formation of ACD6 complexes. (A) Splitluciferase complementation assays indicating interaction of ACD6-Est-I with both MHAI and MHAL in Nicotiana benthamiana. (B) Co-IP assays with A. thaliana Col-0 protoplasts showing interaction of ACD6-Col-0 with MHAI and both N- (residues I-34) and C-terminal (residues 20-72) fragments of MHAL. (C) GST pull-down assay demonstrating interaction of the ANK domains of ACD6-Col-0 with MHAL and, less strongly, with MHAI. (D) Localization of MHAIEst-I-GFP in root cells; cell walls were stained with propidium iodide (PI). Scale bar, $50 \mu \mathrm{m}$. (E) Change of subcellular localization of MHAI-Est-I-GFP in response to $10 \mu \mathrm{M}$ BFA (45 min after treatment). Plasma membranes stained with FM4-64. Scale bar, $50 \mu \mathrm{m}$. (F-H) Subcellular microsomal fractionation of (F) p35s::MHA I-GFP, (G) p35s::GFP-MHAL and (H) PACD6::ACD6-Col-O-FLAG transgenic plants. T, total; S, supernatant; M, microsomal fraction. (I) BN-PAGE and SDS-PAGE showing that MHAL overexpression enhances accumulation and complex formation of ACD6. Increased RNA levels due to the presence of the ACD6-Col-0-FLAG transgene, as measured by qRT-PCR, indicated as means ( \pm $\mathrm{SD})$ at the bottom. Experiments were repeated twice with similar results.

To understand how MHAL enhances the activity of ACD6 protein, we investigated ACD6 accumulation and complex formation in $A$. thaliana plants using Blue Native polyacrylamide gel electrophoresis (BN-PAGE), which was previously used to show that ACD6 exists in complexes of around 700-800 kDa (Zhang et al., 20I7, 2014). Overexpression of MHAL increased the total levels of ACD6 and that of large ACD6 complexes (Figure 4I), similar to what has been shown for the mutation in acd6-I, which, like MHAL overexpression, enhances ACD6 activity (Lu et al., 2003; Zhang et al., 20I4). The higher levels of ACD6 complexes in MHAL overexpressors were apparently mainly due to increased accumulation of ACD6 protein, rather than ACD6 RNA (Figure 4I).

\section{$\mathrm{Ca}^{2+}$ and ACD6 triggered immunity}

That ACD6 activity was modulated by molecules from both intracellular (MHAI and MHAL) and extracellular (MHA2) compartments, led us to hypothesize that ACD6, a membrane-associated protein with multiple predicted transmembrane domains, facilitates the transport of signalling molecules across the plasma membrane. To determine whether ACD6 might be structurally similar to other proteins with such activities, we performed HHpred profile Hidden Markov Model searches (Zimmermann et al., 2018) and found multiple excellent hits to transient receptor potential (TRP) channels from animals and fungi, which regulates ion flux 
bioRxiv preprint doi: https://doi.org/10.1101/2021.01.25.428077; this version posted January 26, 2021. The copyright holder for this preprint (which was not certified by peer review) is the author/funder, who has granted bioRxiv a license to display the preprint in perpetuity. It is made available under aCC-BY 4.0 International license.

Zhu et al.

Regulation of ACD6 ion channel-like protein by small peptides

in response to stimuli ranging from heat to natural products and proinflammatory agents (Julius, 20I3; Venkatachalam and Montell, 2007) (Figure 5-figure supplement I A). Alignments revealed extensive similarity of ACD6 and TRP family ankyrin repeats (Figure 5-figure supplement IB), but not to the transmembrane domains (Huffer et al., 2020). Out of 12 loss-of-function mutations mapping to the ACD6 ankyrin repeats, eight of the affected residues were identical in alignments to at least two out of the three top HHPred hits, fly NOMPC, human TRPAI, and rat TRPV6 (Figure 3D). The A. thaliana genome encodes over 100 ankyrin repeat proteins, with many of them having transmembrane domains (Becerra et al., 2004). ACD6 protein has been predicted to contain up to seven transmembrane domains (Lu et al., 2003), but we could reliably identify only five transmembrane domains (Krogh et al., 200I). Furthermore, homology modeling did not suggest that the structure of the ACD6 transmembrane domains is consistent with those of TRP channels, which have six transmembrane helices, with helices 5 and 6 forming the ion pore in a functional TRP multimeric ion channel (Julius, 20I3; Venkatachalam and Montell, 2007) (Figure 5-figure supplement IC).

Given the similarity of ACD6 and TRP channel ankyrin repeats, we proceeded to investigate potential channel activity of ACD6 using African clawed frog (Xenopus laevis) oocytes. We observed small inward currents after addition of external $\mathrm{Na}+$ in oocytes expressing ACD6 variants, but the difference to the control was only statistically significant for the ACD6-I gain-of-function variant.

A

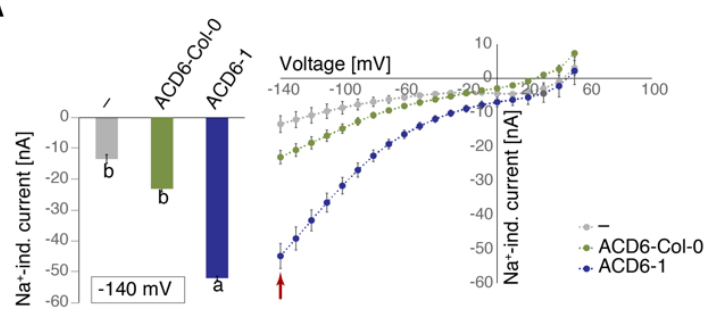

D

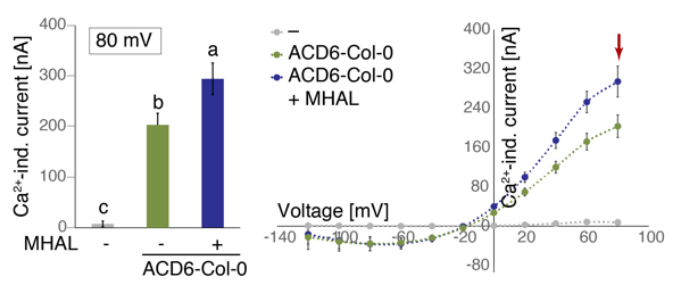

B

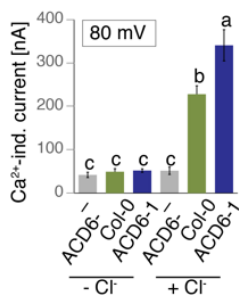

E

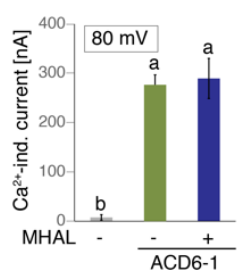

C
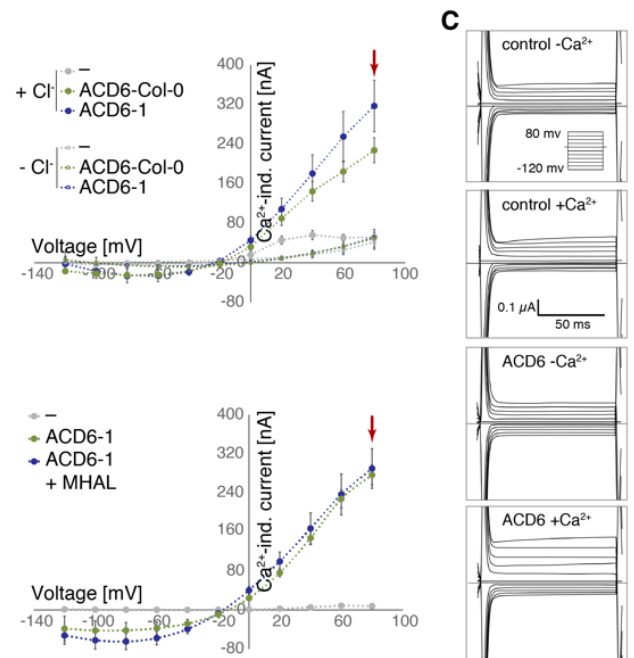

Figure 5. Stimulation of ion channel activity by ACD6 in oocytes and enhancement by MHAL. (A) Currents induced by $10 \mathrm{mM} \mathrm{Na}{ }^{+}$in Xenopus laevis oocytes kept in choline chloride dominated solution and expressing ACD6-Col-0 or ACD6-I. (B) Currents induced by $10 \mathrm{mM} \mathrm{Ca}{ }^{2+}$ in ACD6 variants-expressing oocytes in the presence or absence of $\mathrm{Cl}^{-}$. On the right, the data points for ACD6-I without $\mathrm{Cl}^{-}$are obscured by the ACD6-Col-0 data points without $\mathrm{Cl}^{-}$. (C) Representative original current traces from ACD6-Col-0 recordings (B) in $\mathrm{Cl}^{-}-$ containing solution in the presence and absence of $\mathrm{Ca}^{2+}$. Voltage protocol and scale for all traces are indicated. (D, E) MHAL enhancement of $\mathrm{Ca}^{2+}$-induced currents in oocytes expressing ACD6-Col-0 (C), but not ACD6-I (D). Left, currents at - I $40 \mathrm{mV}(\mathrm{A})$ or $80 \mathrm{mV}$ (B, C, D). Right, current-voltage relations of a representative oocyte batch; red arrows indicate voltages shown for comparisons on the left. Shown are means $(n>3[A]$, or $n>5[B, C, D]) \pm S E$; letters indicate significantly different groups ( $p<0.0$ I [A, B], $p<0.05$ [C, D]; post hoc Tukey's HSD). Controls (“-”): non-injected oocytes. 
Direct observation of $\mathrm{Ca}^{2+}$ influx is hampered in Xenopus oocytes by the presence of endogenous $\mathrm{Ca}^{2+}-$ activated chloride channels. These are stimulated by the accumulation of intracellular $\mathrm{Ca}^{2+}$ and typically mask small ionic currents from $\mathrm{Ca}^{2+}$ influx. However, these endogenous channels can be used as quantitative readout for channel-mediated $\mathrm{Ca}^{2+}$ influx by foreign functional $\mathrm{Ca}^{2+}$ channels (Hartzell et al., 2005; Tian et al., 2019). When we raised the external $\mathrm{Ca}^{2+}$ concentration in our experiments with oocytes expressing the standard ACD6-Col0 or gain-of-function ACD6-I variant, we observed ionic currents that resembled $\mathrm{Ca}^{2+}$-activated chloride currents in their current-voltage relationship; these currents were lost upon removal of external chloride (Figure 5A,B). Consistent with the role of MHAL as an ACD6 activator in plants, MHAL could further enhance these currents in ACD6-Col-0 expressing oocytes, though not in ACD6-I expressing oocytes (Figure 5C,D). Together, these results showed that ACD6 stimulates ion channel activity when expressed in oocytes, perhaps with ACD6 itself as a $\mathrm{Ca}^{2+}$-permeable ion channel.

Since ACD6 could stimulate $\mathrm{Ca}^{2+}$ influx in oocytes, we further tested whether $\mathrm{Ca}^{2+}$ is required for ACD6-triggered immunity. To this end, we cultured the gain-of-function mutant acd6-I in a hydroponic system that contained either 1.5 or $0.1 \mathrm{mM}$ external $\mathrm{Ca}^{2+}$. Similar to the $\mathrm{Ca}^{2+}$ channel mutant death, no defense $\mathrm{I}$ (dnd I-I) (Tian et al., 20I9), we found that depletion of $\mathrm{Ca}^{2+}$ attenuated signs of autoimmunity and expression of PRI in acd6-I (Figure 6A). We also tested the effects of external $\mathrm{Ca}^{2+}$ on the increased growth of Pst DC3000 hrcC- bacteria, which elicit PTI, in acd6-2 loss-of-function mutants (Tateda et al., 2014). Consistent with $\mathrm{Ca}^{2+}$ being required for $A C D 6$ activity, the difference between acd6-2 mutants and wild-type plants disappeared when external $\mathrm{Ca}^{2+}$ was depleted (Figure 6B).

A

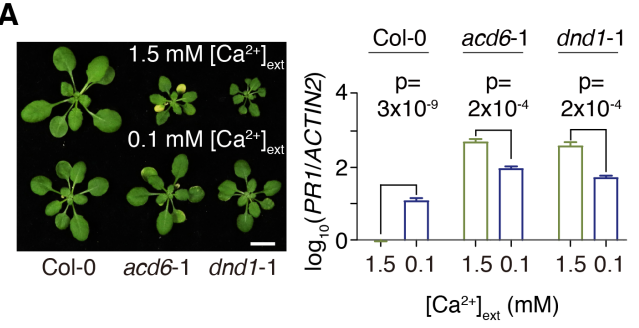

B

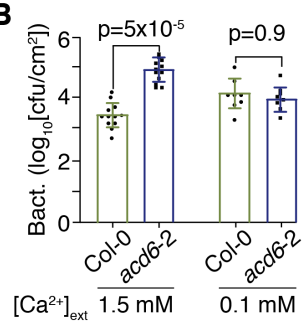

Figure 6. $\mathrm{Ca}^{2+}$ is essential for ACD6 triggered autoimmunity and PTI responses. (A) Left, rosettes of 3-week-old plants grown with different concentrations of external $\mathrm{Ca}^{2+}$. Right, accumulation of PRI mRNA, as measured by $\mathrm{qRT}$-PCR from three biological replicates each. The experiment was repeated twice with similar results. Scale bar, I

$\mathrm{cm}$. (B) Growth of Pst DC3000 hrcC bacteria after 4 days of infection in plants cultured with different concentrations of external $\mathrm{Ca}^{2+}$. The experiment was repeated twice with similar results. p-values from Tukey's HSD.

\section{Discussion}

Epistasis has been proposed as one of the explanations for missing heritability in genetic mapping studies (Eichler et al., 2010; Mackay, 2014; Manolio et al., 2009), with particular challenges presented by alleles that on their own do not seem to have obvious phenotypic effects, a phenomenon known as cryptic genetic variation (Gibson and Dworkin, 2004; Paaby and Rockman, 20I4). Here, we have demonstrated the power of GWA studies of sub-populations carrying specific alleles to identify cryptic modifiers, resulting in the discovery of a family of small peptides that modulate the activity of the immune regulator ACD6 by binding to its ankyrin repeats.

Our study began with $A$. thaliana accessions carrying the naturally hyperactive ACD6-Est-I allele, whose phenotypic effects in different genetic backgrounds depend on two unlinked loci, MHAI and MHA2. 
bioRxiv preprint doi: https://doi.org/10.1101/2021.01.25.428077; this version posted January $26,2021$. The copyright holder for this preprint (which was not certified by peer review) is the author/funder, who has granted bioRxiv a license to display the preprint in perpetuity. It is made available under aCC-BY 4.0 International license.

Suppressor alleles at MHAI and MHA2 are more likely to be found in ACD6-Est-I carriers than in individuals with the standard ACD6 allele, suggestive of selection for specific combinations of ACD6/MHA I/MHA2 alleles. Follow-up studies of MHAI and its paralog MHAL in turn identified a new gene family that regulates plant immunity and led to new insights into the biochemical activity of ACD6. Because MHAI and MHAL encode only small proteins, they constitute small targets for mutagenesis and thus would not have been easily found in conventional genetic screens.

We discovered that the ankyrin repeats of ACD6 are similar in sequence to those of mammalian TRP proteins, and that as TRP proteins, ACD6 functions can stimulate ion flux across membranes (Figure 5-figure supplement I). There is enormous knowledge on the structure and function of TRP ion channels, providing potential models for understanding the activity of ACD6 (Huffer et al., 2020; Julius, 2013; Venkatachalam and Montell, 2007). Similar to a subset of TRP proteins, ACD6 can apparently be regulated through its ankyrin repeats by small ligands, the MHAI and MHAL proteins, with MHAL enhancing the activity of both the standard ACD6 protein and its derivative mutant ACD6-I protein, but not of the ACD6Est-I variant. In contrast, MHAI-Ty-0, but not the standard MHAI protein, can suppress activity of the ACD6-Est-I variant (Figure 5-figure supplement 2A).

TRP channels typically function as tetramers, with two membrane-spanning helices from each subunit contributing to the ion channel pore (see (Huffer et al., 2020) for a recent compilation of TRP channel structures). ACD6 is also found in a large complex (Zhang et al., 2017, 2014) (Figure 4I), but the size of this complex is substantially greater than that of a simple tetramer, suggesting either a higher oligomeric state or association with additional proteins. Several TRP channels can form heteromultimers, with heteromultimers often having different activities than the homomultimers (Venkatachalam and Montell, 2007). In A. thaliana, combinations of natural ACD6 alleles, including those from the Mir-0 and Se-0 accessions, can lead to increased ACD6 hyperactivity in $F_{1}$ hybrids relative to either parent (Świadek et al., 2016; Todesco et al., 20l4) (Figure 5-figure supplement 2B), compatible with a scenario in which the variants assemble into heteromultimers in the $F_{1}$ hybrids that have different properties than the respective homomultimers.

Also similar to ACD6, gain-of-function mutations in TRP channel genes are common, with many of these having been identified as variants underlying human genetic diseases (Myers et al., 2008b). ACD6 itself was originally discovered based on the gain-of-function, hyperactive acd6-I mutant allele induced in the lab (Rate et al., 1999). A hyperactive natural allele, ACD6-Est-I, was subsequently found to be common in natural populations of $A$. thaliana (Todesco et al., 20I0). The Mir-0/Se-0 combination described above can also be considered as a gain-of-function situation. In all four alleles, the sequences responsible for increased activity are found in the predicted transmembrane portion of ACD6 (Figure 5-figure supplement 2B). While some gain-of-function mutations in TRP channels affect either the $\mathrm{N}$-terminal portions including the ankyrin repeats or the $\mathrm{C}$-terminal portions, many alter amino acids in the transmembrane domain (Table 4). This is significant, because, as in ACD6, the overall length of the transmembrane domains is typically much shorter than the length of the other domains, making for a smaller mutational target. 
bioRxiv preprint doi: https://doi.org/10.1101/2021.01.25.428077; this version posted January 26, 2021. The copyright holder for this preprint (which was not certified by peer review) is the author/funder, who has granted bioRxiv a license to display the preprint in perpetuity. It is made available under aCC-BY 4.0 International license.

TRP channels can integrate inputs consisting of different stimuli or ligands, and the opposite effects of MHAI and MHAL on ACD6 activity are reminiscent of the effects of different ligands on TRPVI activity (Lishko et al., 2007). Whether MHAI is a bona fide regulator of ACD6 remains unclear, because we could so far only show that a natural gain-of-function allele acts in a dominant negative fashion to attenuate activity of the ACD6-Est-I allele (Figure 2F). Inactivation of MHAI did not seem to affect ACD6 activity (Figure 2F). It is conceivable that MHAI is a regulator of an ACD6 homolog; $A$. thaliana genomes encode about half a dozen proteins with close similarity to ACD6 in both the ankyrin repeats and transmembrane domains. Redundancy among these proteins may also explain why inactivation of ACD6 has relatively minor consequences (Lu et al., 2003) compared to the pronounced phenotypic effects resulting from ACD6 hyperactivity or MHAL overexpression (Rate et al., 1999; Świadek et al., 2016; Todesco et al., 2014, 2010) (this work). On the other hand, the effects of MHAL overexpression seem to be entirely dependent on ACD6, pointing to an exclusive relationship between MHAL and ACD6. It may appear surprising that MHAL enhances accumulation of an ACD6 complex, rather than merely regulating its activity, but increased accumulation of ACD6 has also been observed in acd6-I mutants (Zhang et al., 2014), consistent with positive feedback regulation of ACD6. A possibility is that MHAL does not directly regulate ACD6 activity, but instead stabilizes ACD6 via other membrane-resident proteins with which ACD6 associates (Tateda et al., 2014; Zhang et al., 2017, 2014). Indeed, ACD6 has been shown to be regulated by protein degradation in the cytoplasm (Zhang et al., 20l4).

Although the ankyrin repeats of TRP proteins are similar to those of ACD6 and related plant proteins, it is unclear whether the ACD6 transmembrane domains adopt a similar topology as TRP channels and therefore whether it acts as an ion channel itself (Figure 5-figure supplement IC). Nevertheless, ACD6 can stimulate $\mathrm{Ca}^{2+}$ influx in a heterologous system (Figure 5) and several of its effects in planta require $\mathrm{Ca}^{2+}$ (Figure 6). $\mathrm{Ca}^{2+}$ influx from extracellular stores is an early event in the host response to pathogens, with relatively well characterized downstream steps. One of the earliest cellular responses to PAMPs is the rapid increase of cytoplasmic $\mathrm{Ca}^{2+}$ levels, indicating that $\mathrm{Ca}^{2+}$ channels are intimately associated with PTI. In agreement, genetics has implicated cyclic nucleotide-gated channel (CNGCs) in this process for a while, and at least one of these CNGCs is a functional $\mathrm{Ca}^{2+}$ channel whose activity is regulated by pathogenand damage-associated molecular patterns (PAMPs/DAMPs), such as lipopolysaccharide (LPS), flagellin 22 (flg22) and plant elicitor peptide 3 (Pep3) (Bredow and Monaghan, 2019; Ma and Berkowitz, 2007; Moeder et al., 2019; Qi et al., 2010; Seybold et al., 2014; Tian et al., 2019). PAMPs also regulate activity of $\mathrm{Ca}^{2+}$ channels from the OSCA family, which are important in stomata-dependent immunity (Thor et al., 2020).

Similar to the induced acd6-I and the natural ACD6-Est-I alleles, mutations in genes for several plant $\mathrm{Ca}^{2+}$ channels and transporters, including the ACAI and ACA4 $\mathrm{Ca}^{2+}-\mathrm{ATPases}$, the CAXI and CAX3 vacuolar $\mathrm{H}^{+} / \mathrm{Ca}^{2+}$ transporters, and the CNGC2/DNDI and CNGC4/DND2 $\mathrm{Ca}^{2+}$ channels, can cause autoimmunity (Cheng et al., 2005; Clough et al., 2000; Hilleary et al., 2020; Tian et al., 2019). We propose that ACD6 modifies PAMP-triggered $\mathrm{Ca}^{2+}$ signals, supported by the finding that the $\mathrm{Ca}^{2+}$ environment affects both autoimmunity in acd6-I gain-of-function mutants and the proliferation of PTI-inducing Pst DC3000 hrcCbacteria in acd6-2 loss-of-function mutants (Figure 6). $\mathrm{Ca}^{2+}$ likely also plays a role in ETI, as cngc2/dnd I 
bioRxiv preprint doi: https://doi.org/10.1101/2021.01.25.428077; this version posted January $26,2021$. The copyright holder for this preprint (which was not certified by peer review) is the author/funder, who has granted bioRxiv a license to display the preprint in perpetuity. It is made available under aCC-BY 4.0 International license.

mutants are impaired in the response to both avirulent and virulent bacterial pathogens (Clough et al., 2000). Moreover, $\mathrm{Ca}^{2+}$ channel blockers suppress cell death activated by the NLRs RPMI and ZARI (Grant et al., 2000; J. Wang et al., 2019). ACD6 in turn has been genetically linked to the NLR SNCI (Zhu et al., 2018) and to helper NLRs of the ADRI and NRGI families (Figure 3C and Figure 5-figure supplement 2). Our discovery of the MHAI/MHAL family of peptides strengthens the case for ACD6 being a dynamic immune regulator, since MHAL, which can activate strong, ACD6-dependent immune responses, appears to be transcriptionally induced upon pathogen infection (Figure 3-figure supplement IE).

Several other ACD6-related transmembrane domain proteins with ankyrin repeats are involved in plant immunity. Cereals encode a series of ACD6 related proteins (Vo et al., 2015), and one of these has been implicated in resistance to the smut fungus Ustilago maydis in maize (Zhang et al., 2019). In A. thaliana, BDAI, predicted to have four instead of six transmembrane segments as in ACD6 and TRP proteins, is required for activity of the receptor-like protein SUPPRESSOR OF NPRI-I, CONSTITUTIVE 2 (SNC2) in plant immunity (Yang et al., 20I2). As with the induced acd6-I gain-of-function allele and the natural hyperactive $A C D 6$ alleles, a mutation causal for BDA I gain-of-function activity maps to the transmembrane domain. Whether any of these ACD6 homologs depend at least in part on small peptide ligands remains to be determined.

Finally, it will be worth investigating in more detail the role of the ACD6 modifier MHA2, which encodes an extracellular subtilase (Figure I and Figure I-figure supplement 4). Plant genomes encode large numbers of subtilases, several of which play a role in biotic defense (Schaller et al., 2018). This may include processing of other extracellular proteases required for defense (Paulus et al., 2020), or perhaps the generation of danger-associated molecular patterns (DAMPs), which trigger PTI (Ramírez et al., 20I3; Reichardt et al., 2018). Of particular interest will thus be to learn whether ACD6 can be directly activated by extracellular signals.

In summary, our results demonstrate a complex set of epistatic relationships between different alleles and paralogs in this system, and positive (ACD6-Est-I and acd6-I, MHAL overexpression) or negative (MHAI-Ty-0) gain-of-function activities. Further complexity is added by the aggregate activity in this system being either temperature-sensitive or -insensitive, depending on the MHAL-requirement of the ACD6 allele. The nature of the cryptic modifiers of $A C D 6$ activity led us to investigate new aspects of the biochemical function of ACD6, which revealed it to be a modulator of ion influx, with ACD6 itself possibly being an ion channel that is regulated by peptides that bind to its intracellular ankyrin repeats. Our findings thus illustrate once more how naturally evolved special alleles, which are unlikely to be recoverable from conventional mutant screens, can provide new insights into fundamental aspects of plant biology.

\section{Materials and methods}

Plant material and growth. Arabidopsis thaliana accessions (Table I) and Nicotiana benthamiana were derived from stocks maintained in the lab. Seeds were germinated and cultivated in growth rooms at a constant temperature of $23^{\circ} \mathrm{C}$ or $16^{\circ} \mathrm{C}$, air humidity at $65 \%, 16 \mathrm{hr}$ (long days) or $8 \mathrm{hr}$ (short days) day length, under II 0 to $140 \mu \mathrm{mol} \mathrm{m}^{-2} \mathrm{~s}^{-1}$ light provided by Philips GreenPower TLED modules (Philips Lighting GmbH, 
bioRxiv preprint doi: https://doi.org/10.1101/2021.01.25.428077; this version posted January $26,2021$. The copyright holder for this preprint (which was not certified by peer review) is the author/funder, who has granted bioRxiv a license to display the preprint in perpetuity. It is made available under aCC-BY 4.0 International license.

Hamburg, Germany) with a mixture of 2:I DR/W LB (deep red/white mixture with ca. I5\% blue) and W HB (white with ca. $25 \%$ blue), respectively.

The hydroponic system used for assessing the effects of $\mathrm{Ca}^{2+}$ has been described (Vasseur et al., 2019) and was used with minor modifications. In brief, the plants were cultivated on inorganic solid media, and all nutrients were provided through the watering solution. The hydroponic medium contained I mM $\mathrm{KH}_{2} \mathrm{PO}_{4}$, I mM MgSO $4,0.25 \mathrm{mM} \mathrm{K} \mathrm{SO}_{4}, 0.1 \mathrm{mM} \mathrm{C}{ }_{10} \mathrm{H}_{12} \mathrm{FeN}_{2} \mathrm{NaO}_{8}$, micronutrients $(50 \mu \mathrm{M} \mathrm{KCl}, 30 \mu \mathrm{M}$ $\mathrm{H}_{3} \mathrm{BO}_{3}, 5 \mu \mathrm{MnSO}_{4}, \mathrm{I} 5 \mu \mathrm{M} \mathrm{ZnSO}_{4}$, I $\mu \mathrm{MCuSO}_{4}$, I $\mu \mathrm{M} \mathrm{NaMoO}{ }_{4}$ ), I mM NH $\mathrm{NNO}_{3}$, I mM NH $\mathrm{N}_{4} \mathrm{Cl}$, I mM $\mathrm{KNO}_{3}$ and different concentrations of $\mathrm{CaCl}_{2}(\mathrm{pH} 5.8$, adjusted with $\mathrm{KOH})$.

Genome-wide association study (GWAS). Severity of leaf necrosis was scored on an arbitrary scale from I to 5 using six biological replicates (Table I), and GWAS with efficient mixed-model (EMMAX) methods was performed with the easyGWAS web interface (Grimm et al., 2016). The Bonferroni correction with a threshold of 0.05 for multiple testing corresponded to an uncorrected $p$-value of $7.6 \times 10-8$. The variance explained (adjusted $R^{2}$ ) by the two loci was estimated using a Generalized Linear Model (GLM) using $R$ ( $R$ Core Team, 2019), with necrosis as response variable and the two SNPs targeting the MHA loci as fixed effects with an interaction term.

Linkage mapping in crosses. We scored Ty-0 $x$ Est-I $F_{2}$ individuals for the severity of leaf necrosis on an arbitrary scale from 0.5 to 10. Days to visible leaf necrosis were taken into account as well in this score. We analyzed $798 F_{2}$ individuals, extracted genomic DNA from $190 F_{2}$ individuals with extreme phenotypes (97 with scores of 0.5-3 and 93 with scores of 8.5-10), prepared RAD-seq libraries with barcodes for multiplexing after Kpnl digestion (Rowan et al., 2017), and sequenced the samples on a HiSeq2000 instrument (Illumina, San Diego, CA, USA) with 150 bp single-end reads. After de-multiplexing using SHORE (https://sourceforge.net/projects/shore), reads were mapped to the TAIR 10 reference genome using BWAMEM (Li and Durbin, 2009). bcftools (Li et al., 2009) and vcftools (Danecek et al., 20I I) were used to call SNPs and generate the final VCF file, which was then processed using R (https://www.r-project.org/) for quality control and for generating a SNP matrix for QTL mapping. Whole-genome linkage analysis was performed using R-qtl (Broman et al., 2003), and LOD scores were calculated under a single-QTL model using the function "scanone" with the expectation-maximization (EM) algorithm.

The LOD score significance threshold was established using I,000 permutations. To fine map MHAI, 8,000 $F_{3}$ progeny of $F_{2}$ individuals heterozygous at $M H A /$ but homozygous in the other three $Q T L$ regions were scored for leaf necrosis. We genotyped $\mathrm{I}, \mathrm{I} 57$ of the $\mathrm{F}_{3}$ individuals with suppressed leaf necrosis using SSLP markers around MHAI (Table 5). A Heterogeneous Inbred Family (HIF) (Loudet et al., 2005) was used to establish $\mathrm{F}_{6}$ generation Near Isogenic Lines (NILs) that differed only in the MHAI region.

Phylogenetic analysis of MHA2 DNA sequences. Eight-seven MHA2 sequences, extracted from the I00I Genomes dataset (http:// I00 Igenomes.org) (I00I Genomes Consortium, 2016), were used to infer phylogenetic relationships with Maximum likelihood (ML) approaches in MEGA6 (Tamura et al., 20I3), using MHA2's homolog SBT2.3 (AT5G44530) as outgroup. Node confidence was estimated with I,000 bootstrap replications. 
bioRxiv preprint doi: https://doi.org/10.1101/2021.01.25.428077; this version posted January $26,2021$. The copyright holder for this preprint (which was not certified by peer review) is the author/funder, who has granted bioRxiv a license to display the preprint in perpetuity. It is made available under aCC-BY 4.0 International license.

Linkage disequilibrium calculation. Genomic regions surrounding MHAI and MHA2 were subsetted from a short read VCF of 1001 Genomes data (100I Genomes Consortium, 2016) using vcftools version I5.I (Danecek et al., 20II). Linkage disequilibrium $\mathrm{R}^{2}$ values were calculated with PLINK version I.9, with a window of $15 \mathrm{~kb}$ and an $\mathrm{R}^{2}$ threshold of 0 .

Transgene-free genome-edited lines. An A. thaliana codon-optimized Cas9 (athCas9) (Li et al., 20|3) was used, with the final pUBQ10::athCas9:trbcs:::gRNAI:::gRNA2::mCherry constructs assembled from six GreenGate modules (Lampropoulos et al., 2013). Module A - A. thaliana pUBQ 10; B - A. thaliana codonoptimized Cas9; C - rbcs terminator; D and E - sgRNAs (Table 6) expressed from A. thaliana U6 promoter (Li et al., 20I3); F - pAT2S3::mCherry:tMAS cassette (Gao et al., 2016) for selection of seeds with or without the transgene. Target regions were PCR amplified using oligonucleotide primers in Table 7.

qRT-PCR. RNA was extracted from at least three biological replicates of pooled seedlings using the RNeasy kit (Thermo Fisher Scientific, Waltham, MA, USA), and treated with DNase I (Thermo Fisher Scientific). We used $2 \mu \mathrm{g}$ of high-quality samples with A260/A230>2.0 and A260/A280>1.8 as determined with a ND-2000 spectrophotometer (Nanodrop Technologies, San Francisco CA, USA) as template for reverse transcription with the M-MLV Reverse Transcriptase kit (Thermo Fisher Scientific). Quantitative real-time PCR reactions were performed using Maxima SYBR ${ }^{\circledR}$ Green Master Mix (Thermo Fisher Scientific) on a CFX384 instrument (Bio-Rad, Hercules, CA, USA). Transcript abundance was normalized to ACTIN 2 (AT3G 18780). Primers are listed in Table 7.

Transgenic lines. An ACD6 fragment corresponding to Chr4: $8292084 . .8298360$ in the TAIR I 0 reference genome was amplified from Ty-0 genomic DNA with PCR primers designed based on the ACD6-Est-I sequence. To generate PACD6::ACD6-3xFLAG (ACD6-FLAG), genomic DNA was amplified from Est-I and Col0 plants using an oligonucleotide primer that contained 3xFLAG coding sequence. Fragments were cloned into Gateway entry vector PCR8/GW/TOPO (Thermo Fisher Scientific) and moved into the binary vector pFK206, a modified pGREEN vector with rbsc terminator (Hellens et al., 2000) .

For MHAI, MHA2 and MHAL overexpression constructs, coding regions were amplified and cloned into PCR8/GW/TOPO, moved into binary vector PFK210, a modified PGREEN vector with a 35S CaMV promoter and rbsc terminator (Hellens et al., 2000), and introduced into pFAST-G02 (Shimada et al., 20I0), which contains a seed coat fluorescence marker. To tag MHAI and MHAL proteins, mGFP coding sequences were added to MHAI and MHAL coding sequences using Gibson assembly (NEB, Ipswich, MA, USA). We also generated $2.1 \mathrm{~kb}$ genomic constructs for both MHAI-Est-I and MHAI-Ty-0 (pMHAI::MHAI-Est-I and pMHAI::MHAI-Ty-0) with pCR8/GW/TOPO and pFK206. Constructs are listed in Table 8.

Mutant screen for p35s::MHAL suppressors. 20,000 seeds of a $\mathrm{p} 35 \mathrm{~S}::$ MHAL homozygous line were treated with $0.2 \%$ EMS overnight, followed by thorough rinses with water and sowing the seeds on soil. $M_{2}$ seeds were collected in 640 pools. In the $M_{2}$ generation, we screened for non-necrotic, normal-sized plants. Phenotypic suppression was confirmed in the $M_{3}$ generation. Genomic DNA of $M_{3}$ plants was extracted, tagmented (Picelli et al., 20I4; Rowan et al., 2017), and sequenced on an HiSeq3000 instrument (Illumina) 
bioRxiv preprint doi: https://doi.org/10.1101/2021.01.25.428077; this version posted January 26,2021 . The copyright holder for this preprint (which was not certified by peer review) is the author/funder, who has granted bioRxiv a license to display the preprint in perpetuity. It is made available under aCC-BY 4.0 International license.

with I50 bp single-end reads. Raw reads were mapped to the TAIR I0 reference genome using BWA-MEM (Li and Durbin, 2009). bcftools (Li et al., 2009) and vcftools (Danecek et al., 20I I) were used to call SNPs and generate the final VCF file, followed by snpEff (Cingolani et al., 20I2) annotation of SNP effects. Mutations shared by all lines were removed, and genes with at least three independent G>A or C>T mutations predicted to cause non-synonymous changes or truncate the open reading frame were analyzed in detail.

Trypan Blue staining. Freshly harvested leaf tissue was stained by completely immersing it in lactophenol/Trypan Blue staining solution (10 mL lactic acid, $10 \mathrm{~mL}$ glycerol, $10 \mathrm{~mL}$ phenol, $10 \mathrm{mg}$ Trypan Blue and $10 \mathrm{~mL}$ water) and heating in a heat block at $80^{\circ} \mathrm{C}$ for I hour. Staining solution was aspirated and replaced by chloral hydrate solution $(2.5 \mathrm{~g} / \mathrm{mL})$ to destain and clear the tissue. This was repeated once overnight to improve clearing. Samples were kept in $60 \%(\mathrm{v} / \mathrm{v})$ aqueous glycerol for storage and further imaging.

Pseudomonas infection. Pst DC3000 avrRpt2 was grown to $\mathrm{OD}_{600}$ of 3.0 in KB medium, pelleted at 4,000 rpm and resuspended in $10 \mathrm{mM} \mathrm{MgCl} 2$ at $5 \times 10^{5}$ colony-forming units $(\mathrm{cfu}) / \mathrm{ml}$. The suspension was infiltrated into leaves of 4-week-old A. thaliana plants with a needleless syringe. Bacterial growth was determined at 3 days post-inoculation by colony counting $(3 \mathrm{dpi})$. The experiment was repeated twice. The bacterial growth assay of Pst DC3000 hrcC-followed a published protocol (Tian et al., 2019). In brief, an overnight culture strain was pelleted and resuspended in $10 \mathrm{mM} \mathrm{MgCl} 2$ at Ix $10^{8} \mathrm{cfu} / \mathrm{ml}$ in $0.03 \%$ Silwet L-77 (Helena, Collierville, TN, USA). Plants were dipped in the bacterial suspension for 30 seconds, and covered with a clear plastic lid. At 4 days post-inoculation, leaf discs were collected and surface sterilized (30 sec in $70 \%$ ethanol, followed by $30 \mathrm{sec}$ in sterile distilled water) for colony assays.

Confocal microscopy. Five-day-old A. thaliana seedlings were imaged on a TCS SP8 confocal microscope (Leica, Wetzlar, Germany) with a 40x water corrected objective (I.10 NA) and a $488 \mathrm{~nm}$ excitation laser at $5 \%$ intensity. GFP emission was captured from 499 to $559 \mathrm{~nm}$ with a photomultiplier tube, at a gain of 450.3 . Propidium lodide emission was captured from 576 to 69I nm with a Hybrid detector, at a gain of 55.3. For the BFA assay, the laser intensity was reduced to $2 \%$. GFP emission was captured from 507 to $539 \mathrm{~nm}$ with a Hybrid detector, at a gain of 10. FM4-64 emission was captured from 705 to $755 \mathrm{~nm}$ with a Hybrid detector, at a gain of 50 . Images were combined to a frame average of 4 .

Subcellular fractionation. We followed a published protocol (El Kasmi et al., 2017) with modification. About $100 \mathrm{mg}$ of 10 -day-old $A$. thaliana seedlings were ground on ice with pestle and mortar. $200 \mu \mathrm{L}$ sucrose buffer (20 mM Tris [pH 8], $0.33 \mathrm{M}$ sucrose, I mM EDTA, I mM DTT and protease inhibitor cocktail) was added. Samples were spun at $2,000 \mathrm{~g}$ for 10 minutes at $4^{\circ} \mathrm{C}$ to remove plant debris. $45 \mu \mathrm{L}$ supernatant was removed as total lysate fraction (T). The rest was centrifuged at $20,000 \mathrm{~g}$ for I hr at $4^{\circ} \mathrm{C} .45 \mu \mathrm{L}$ of the resulting supernatant was used as the soluble fraction (S). The membrane pellet was resuspended in $45 \mu \mathrm{L}$ sucrose buffer and used as microsomal fraction (M).

Split-luciferase complementation assay. We followed a published protocol (Chen et al., 2008). Agrobacterium tumefaciens GV3I0I with expressions constructs for ACD6-cLuc, MHAI-Est-I-nLuc or MHAI-Ty-0-nLuc were suspended at $5 \times 10^{8} \mathrm{cfu} / \mathrm{ml}$ in half-strength MS medium. The suspension was 
bioRxiv preprint doi: https://doi.org/10.1101/2021.01.25.428077; this version posted January $26,2021$. The copyright holder for this preprint (which was not certified by peer review) is the author/funder, who has granted bioRxiv a license to display the preprint in perpetuity. It is made available under aCC-BY 4.0 International license.

infiltrated into the leaves of 30-day-old Nicotiana benthamiana plants. For CCD imaging, leaves were sprayed $48 \mathrm{~h}$ later with I mM D-Luciferin-K (PJK GmbH, Kleinblittersdorf, Germany) in water containing $0.02 \%$ Silwet L-77 (Helena) and kept in the dark for 10 min before measurement. The luminescence signal was recorded with an Orca 2-BT cooled CCD camera (Hamamatsu Photonics, Shizuoka, Japan). The experiment was repeated twice.

Co-immunoprecipitation. ACD6-FLAG was co-expressed with MHAI-GFP and MHAL-GFP in protoplasts isolated from 4-week-old Arabidopsis thaliana transgenic plants. Total protein was extracted with extraction buffer (50 mM HEPES [pH 7.5], 150 mM KCl, I mM EDTA, 0.5\% Triton-X 100, I mM DTT, and proteinase inhibitor cocktail). For anti-GFP co-IP, the extracted proteins were incubated with GFP-Trap_M (ChromoTek $\mathrm{GmbH}$, Planegg, Germany) at $4^{\circ} \mathrm{C}$ under gentle rotation for $2 \mathrm{~h}$. The magnetic particles were washed seven times with washing buffer $(50 \mathrm{mM}$ HEPES [PH 7.5], $150 \mathrm{mM} \mathrm{KCl}$, I mM EDTA, 0.5\% Triton$X 100,1 \mathrm{mMDTT}$ ) at $4^{\circ} \mathrm{C}$. Proteins were detected by immunoblotting using anti-GFP (Santa Cruz, California, USA) and anti-FLAG (Sigma-Aldrich, MO, USA) antibodies.

In vitro pull-down assays. GST- and MBP-6xHis-fusion proteins were expressed in E. coli BL2I. Bacterial cultures in $L B$ were incubated at $28^{\circ} \mathrm{C}$ until an $O_{600}$ of 0.6 and then induced with $0.4 \mathrm{mM} \mathrm{IPTG}$ at $20^{\circ} \mathrm{C}$ for $16 \mathrm{hr}$. Tagged proteins were purified separately using glutathione agarose beads (GE Healthcare, Chicago, USA) or Ni-NTA affinity agarose beads (QIAGEN, Venlo, Netherlands). Purified proteins were dissolved in a buffer containing $25 \mathrm{mM}$ Tris- $\mathrm{HCl}(\mathrm{pH} 7.5), 100 \mathrm{mM} \mathrm{NaCl}$, and I mM DTT and concentrated with Amicon Ultra-15 Centrifugal Filter Units (Millipore, Darmstadt, Germany). $2 \mu \mathrm{g}$ GST-tagged Protein, $20 \mu \mathrm{l}$ Glutathione Sepharose 4B (GE Healthcare) and $10 \mu \mathrm{g}$ MBP-6xHis-tagged protein were taken up in I ml pulldown buffer (25 mM Tris- $\mathrm{HCl}[\mathrm{pH} 7.5], 200 \mathrm{mM} \mathrm{NaCl}, 0.5 \%$ [v/v] Triton X-100) and incubated for $4 \mathrm{hr}$ under gentle rotation. For washing, the beads with bound protein were spun down ( $500 \mathrm{rpm}, 10 \mathrm{~min})$, the supernatant was discarded, beads were resuspended in pull-down buffer and incubated for I hr under gentle rotation. Washing was repeated 6 times. Elution of GST-tagged protein from beads was performed by resuspending pelleted beads $(500 \mathrm{rpm}, 10 \mathrm{~min})$ in $100 \mu$ l Elution buffer $(25 \mathrm{mM}$ Tris- $\mathrm{HCl}[\mathrm{pH} 7.5], 150 \mathrm{mM}$ $\mathrm{NaCl}, 30 \mathrm{mM}$ glutathione) and incubated for I hr under gentle rotation. After centrifugation (I,000 rpm, 20 min), GST-tagged protein eluate was collected from supernatant. Protein purification and pull-down were performed at $4^{\circ} \mathrm{C}$. Proteins were detected by immunoblotting using anti-Glutathione-S-Transferase (SigmaAldrich, MO, USA) and antipolyHistidine-Peroxidase (Sigma-Aldrich, MO, USA) antibodies.

Blue Native-PAGE. Blue native polyacrylamide gel electrophoresis (BN-PAGE) was performed using the Bis-Tris NativePAGE system from Invitrogen (Carlsbad, CA, USA) according to the manufacturer's instructions. Briefly, eight 10-day-old seedlings were collected and ground in I XNativePAGE Sample Buffer (Invitrogen) containing I\% n-dodecyl $\beta$-D-maltoside (DDM) and protease inhibitor cocktail, followed by 13,000 rpm centrifugation for $20 \mathrm{~min}$ at $4^{\circ} \mathrm{C} .20 \mu \mathrm{L}$ supernatant mixed with I $\mu \mathrm{L} \% \mathrm{G}-250$ Sample Additive was loaded and run on a NativePAGE 3-12\% Bis-Tris gel. Native gels were transferred to PVDF membranes (Millipore, Darmstadt, Germany) using NuPAGE Transfer Buffer, followed by protein blotting. For the second 
bioRxiv preprint doi: https://doi.org/10.1101/2021.01.25.428077; this version posted January $26,2021$. The copyright holder for this preprint (which was not certified by peer review) is the author/funder, who has granted bioRxiv a license to display the preprint in perpetuity. It is made available under aCC-BY 4.0 International license.

dimension of electrophoresis, a $5.7 \mathrm{~cm}$ strip of BN-PAGE gel was incubated in Laemmli sample buffer (50 $\mathrm{mM}$ Tris- $\mathrm{HCl}$ [pH 6.8], $100 \mathrm{mM}$ DTT, $2 \%$ (w/v) SDS, $0.1 \%$ bromophenol blue, $10 \%$ (v/v) glycerol) for $10 \mathrm{~min}$, microwaved for $20 \mathrm{sec}$, and then rotated for another $5 \mathrm{~min}$ before loading the strip into the well of a NuPAGE 4-12\% Bis-Tris protein gel (Invitrogen).

Protein homology search and alignment. HHPred search and structure modeling with MODELLER were performed online (https://toolkit.tuebingen.mpg.de/\#/tools/hhpred), using the MPI Bioinformatics Toolkit (Zimmermann et al., 2018). HHPred default search parameter was used for homology searches with ACD6-Col-0 (excluding residues I-90) as query. Alignments were visualized with Jalview (Waterhouse et al., 2009) Default parameters were used for homology modeling with MODELLER (Sali and Blundell, 1993). We used the SMART database (http://smart.embl-heidelberg.de/) to predict the boundaries of the ankyrin repeats in ACD6, and the TMHMM server v2.0 (http://www.cbs.dtu.dk/services/TMHMM/) to predict transmembrane domains. Structures were visualized using PyMOL (Schrödinger LLC, 20I0).

Injection of oocytes and electrophysiological measurements. Dissected and preselected Xenopus laevis oocytes were obtained from Ecocyte Bioscience (Dortmund, Germany). Oocytes were kept in ND96 $(96 \mathrm{mM} \mathrm{NaCl}, 2 \mathrm{mM} \mathrm{KCl}$, I mM MgCl , $1.8 \mathrm{mM} \mathrm{CaCl}$, $2.5 \mathrm{mM}$ sodium pyruvate, $5 \mathrm{mM}$ HEPES adjusted to $\mathrm{pH}$ of 7.4 with $\mathrm{NaOH}$ ). cRNA was produced from Mlul linearized and phenol-chloroform purified pOO2 plasmids (Straub et al., 2017) containing the coding sequences of ACD6-I, ACD6-Col-0 or MHAL using the mMESSAGE mMACHINE TM SP6 Transcription Kit (Life Technologies GmbH, Darmstadt; Germany) following the manufacturer's instructions. Oocytes were injected with $50 \mathrm{nl}$ cRNA with a concentration of $300 \mathrm{ng} / \mu \mathrm{l}$ for ACD6 variants and $0.1 \mathrm{ng} / \mu \mathrm{l}$ for MHAL. Oocytes were kept in ND96 for 3-4 days at $18{ }^{\circ} \mathrm{C}$. Electrophysiology was performed in a small recording chamber containing the recording solution.

For sodium transport measurements the test solution contained $110 \mathrm{mM}$ choline chloride, $2 \mathrm{mM}$ $\mathrm{CaCl}_{2}, 2 \mathrm{mM} \mathrm{MgCl}$, $5 \mathrm{mM} \mathrm{N}$-morpholinoethane sulfonate (MES), pH adjusted to 5.5 with Tris(hydroxymethyl) aminomethane (TRIS) with and without $10 \mathrm{mM} \mathrm{NaCl}$. Recording solutions for calciuminduced chloride currents were: $-\mathrm{Cl}$ solution ( $100 \mathrm{mM}$ sodium glutamate, $5 \mathrm{mM} \mathrm{MES}$, $\mathrm{pH}$ adjusted to 5.5 with

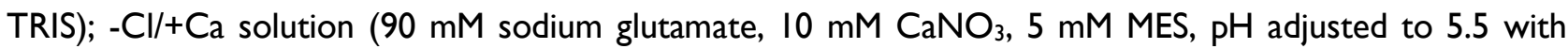
TRIS); -Ca solution ( $100 \mathrm{mM}$ sodium chloride, $5 \mathrm{mM}$ MES, pH adjusted to 5.5 with TRIS) and +Ca solution ( $90 \mathrm{mM}$ sodium chloride, $10 \mathrm{mM} \mathrm{CaCl}, 5 \mathrm{mM}$ MES, pH adjusted to 5.5 with TRIS).

Two-electrode voltage-clamp measurements were performed using $3 \mathrm{M} \mathrm{KCl-filled} \mathrm{glass} \mathrm{capillaries} \mathrm{of}$ around 2 Mohm resistance of the electrodes. For measurements in $-\mathrm{Cl}$ solutions, an agarose bridge was used to connect the recording chamber with a separated reference electrode bathed in $3 \mathrm{M} \mathrm{KCl}$ solution via a glass capillary filled with $3 \mathrm{M} \mathrm{KCl}$ and $2 \%$ agarose. Currents were recorded with 100 ms steps over a range from $+80 \mathrm{mV}$ to $-140 \mathrm{mV}$ in 10 or $20 \mathrm{mV}$ decrements. Electrical recordings were performed after complete wash of the bathing solutions to test solutions and the mean induced currents by the test solutions are shown (background currents were subtracted). Data from representative oocyte batches are shown. 
URLs. Arabidopsis thaliana I00I Genomes Project http://I00/genomes.org; Univ. of Toronto gene expression browser http://bar.utoronto.ca; easyGWAS https://easygwas.ethz.ch; HHPred toolkit.tuebingen.mpg.de.

Accession codes. Sanger sequences are available at Genbank: ACD6-Ty-0 MHI20293, MHAI-Ty-0 MHI 2029I, MHAI-Est-I MHI 20292, MHA2-Est-I MK977584, and MHA2-Ty-0 MK977584.

\section{Acknowledgements}

We thank past and present members of the Weigel lab, Richard Hilleary and Sheng Yang He, Katherine Huffer and Kenton Swartz, and Yalong Guo for discussion, and Farid El-Kasmi, Derek Lundberg, Wei Yuan, Alejandra Duque and Thorsten Nürnberger for comments on the manuscript. We thank Maricris Zaidem for seeds of the Ty- $0 \times$ Est-I $F_{2}$ population and Polina Novikova for resequencing data of natural Arabidopsis lyrata accessions. We thank Monika Demar, Frederik Unger, Sonja Kersten, Kai Wang, and Martin Bayer for help with experiments, and the ZMBP Analytics Laboratory from the University of Tübingen for help with salicylic acid quantification. This work was supported by an EMBO Long-term Fellowship (969-2016 to L.L.), an HFSP Long-term Fellowship (LT0003 I4/20 I7-L to L.L.), the DFG (NE 1727/2-2 to B.N.), a Starting Grant from China Agricultural University (W.Z.), the Ministry of Science Research and Arts Baden-Württemberg through the Regio Research Alliance "Yield Stability in Dynamic Environments" (U.L., D.W.), the DFG through SFBI IOI, and the Max Planck Society (D.W.).

\section{Author Contributions}

Conceptualization: W.Z., L.L., U.Lud., D.W. Methodology: W.Z., L.L., B.N. Formal analysis: W.Z. Investigation: W.Z., L.L., B.N., M.T., M.W., J.C., L.W., K.V., M.E.A., C.L., J.K., A.C.B, R.S., U.Lut.. Writingoriginal draft: W.Z., D.W.. Writing-review, and editing: W.Z., L.L., U.Lud., D.W. Supervision: W.Z., U.Lud., D.W. Project administration: D.W. Funding acquisition: W.Z., L.L., U.Lud., D.W.

\section{Completing Financial Interests}

The authors declare no competing interests.

\section{References}

100I Genomes Consortium. 2016. I,I35 Genomes Reveal the Global Pattern of Polymorphism in Arabidopsis thaliana. Cell 166:48I-49I.

Arbabian A, Iftinca M, Altier C, Singh PP, Isambert H, Coscoy S. 2020. Mutations in calmodulin-binding domains of TRPV4/6 channels confer invasive properties to colon adenocarcinoma cells. Channels I4:10I-109.

Arif Pavel M, Lv C, Ng C, Yang L, Kashyap P, Lam C, Valentino V, Fung HY, Campbell T, Møller SG, Zenisek D, Holtzman NG, Yu Y. 20I6. Function and regulation of TRPP2 ion channel revealed by a gain-offunction mutant. Proc Natl Acad Sci U S A I I 3:E2363-72.

Becerra C, Jahrmann T, Puigdomènech P, Vicient CM. 2004. Ankyrin repeat-containing proteins in 
bioRxiv preprint doi: https://doi.org/10.1101/2021.01.25.428077; this version posted January $26,2021$. The copyright holder for this preprint (which was not certified by peer review) is the author/funder, who has granted bioRxiv a license to display the preprint in perpetuity. It is made available under aCC-BY 4.0 International license.

Arabidopsis: characterization of a novel and abundant group of genes coding ankyrin-transmembrane proteins. Gene 340:III-12I.

Bonardi V, Tang S, Stallmann A, Roberts M, Cherkis K, Dangl JL. 20I I. Expanded functions for a family of plant intracellular immune receptors beyond specific recognition of pathogen effectors. Proc Natl Acad Sci U S A 108:16463-16468.

Boukalova S, Marsakova L, Teisinger J, Vlachova V. 20I0. Conserved residues within the putative S4-S5 region serve distinct functions among thermosensitive vanilloid transient receptor potential (TRPV) channels. J Biol Chem 285:4|455-4|462.

Bredow M, Monaghan J. 2019. Regulation of Plant Immune Signaling by Calcium-Dependent Protein Kinases. Mol Plant Microbe Interact 32:6-19.

Broman KW, Wu H, Sen S, Churchill GA. 2003. R/qtl: QTL mapping in experimental crosses. Bioinformatics 1 9:889-890.

Castel B, Ngou P-M, Cevik V, Redkar A, Kim D-S, Yang Y, Ding P, Jones JDG. 2019. Diverse NLR immune receptors activate defence via the RPW8-NLR NRGI. New Phytol 222:966-980.

Cheng N-H, Pittman JK, Shigaki T, Lachmansingh J, LeClere S, Lahner B, Salt DE, Hirschi KD. 2005. Functional association of Arabidopsis CAXI and CAX3 is required for normal growth and ion homeostasis. Plant Physiol I 38:2048-2060.

Chen H, Zou Y, Shang Y, Lin H, Wang Y, Cai R, Tang X, Zhou J-M. 2008. Firefly luciferase complementation imaging assay for protein-protein interactions in plants. Plant Physiol 146:368-376.

Cingolani P, Platts A, Wang LL, Coon M, Nguyen T, Wang L, Land SJ, Lu X, Ruden DM. 20I2. A program for annotating and predicting the effects of single nucleotide polymorphisms, SnpEff: SNPs in the genome of Drosophila melanogaster strain wIII8; iso-2; iso-3. Fly 6:80-92.

Clough SJ, Fengler KA, Yu IC, Lippok B, Smith RK Jr, Bent AF. 2000. The Arabidopsis dndI "defense, no death" gene encodes a mutated cyclic nucleotide-gated ion channel. Proc Natl Acad Sci U S A 97:93239328.

Contento AL, Bassham DC. 2012. Structure and function of endosomes in plant cells. J Cell Sci I 25:35 I I3518.

Cui H, Gobbato E, Kracher B, Qiu J, Bautor J, Parker JE. 2017. A core function of EDSI with PAD4 is to protect the salicylic acid defense sector in Arabidopsis immunity. New Phytol 2 1 3:I802-18I7.

Danecek P, Auton A, Abecasis G, Albers CA, Banks E, DePristo MA, Handsaker RE, Lunter G, Marth GT, Sherry ST, McVean G, Durbin R, 1000 Genomes Project Analysis Group. 20II. The variant call format and VCFtools. Bioinformatics 27:2156-2I58.

Dong X-P, Wang X, Shen D, Chen S, Liu M, Wang Y, Mills E, Cheng X, Delling M, Xu H. 2009. Activating mutations of the TRPMLI channel revealed by proline-scanning mutagenesis. J Biol Chem 284:3204032052.

Eichler EE, Flint J, Gibson G, Kong A, Leal SM, Moore JH, Nadeau JH. 20I0. Missing heritability and strategies for finding the underlying causes of complex disease. Nat Rev Genet I I :446-450.

El Kasmi F, Chung E-H, Anderson RG, Li J, Wan L, Eitas TK, Gao Z, Dangl JL. 20I7. Signaling from the plasmamembrane localized plant immune receptor RPMI requires self-association of the full-length protein. Proc Natl Acad Sci U S A. doi: 10.1073/pnas. I708288I I 4

Fu ZQ, Dong X. 2013. Systemic acquired resistance: turning local infection into global defense. Annu Rev Plant Biol 64:839-863.

Gaffney T, Friedrich L, Vernooij B, Negrotto D, Nye G, Uknes S, Ward E, Kessmann H, Ryals J. 1993. Requirement of salicylic Acid for the induction of systemic acquired resistance. Science 26 I:754-756.

Gao X, Chen J, Dai X, Zhang D, Zhao Y. 2016. An Effective Strategy for Reliably Isolating Heritable and Cas9-Free Arabidopsis Mutants Generated by CRISPR/Cas9-Mediated Genome Editing. Plant Physiol I7I:I794-I800.

Gazzani S, Lawrenson T, Woodward C, Headon D, Sablowski R. 2004. A link between mRNA turnover and RNA interference in Arabidopsis. Science 306:1046-1048.

Gibson G, Dworkin I. 2004. Uncovering cryptic genetic variation. Nat Rev Genet 5:68I-690.

Grant M, Brown I, Adams S, Knight M, Ainslie A, Mansfield J. 2000. The RPMI plant disease resistance gene facilitates a rapid and sustained increase in cytosolic calcium that is necessary for the oxidative burst and hypersensitive cell death. Plant J 23:44I-450.

Grimm C, Cuajungco MP, van Aken AFJ, Schnee M, Jörs S, Kros CJ, Ricci AJ, Heller S. 2007. A helix-breaking mutation in TRPML3 leads to constitutive activity underlying deafness in the varitint-waddler mouse. Proc Natl Acad Sci U S A 104:19583-19588.

Grimm DG, Roqueiro D, Salome P, Kleeberger S, Greshake B, Zhu W, Liu C, Lippert C, Stegle O, Schölkopf 
bioRxiv preprint doi: https://doi.org/10.1101/2021.01.25.428077; this version posted January $26,2021$. The copyright holder for this preprint (which was not certified by peer review) is the author/funder, who has granted bioRxiv a license to display the preprint in perpetuity. It is made available under aCC-BY 4.0 International license.

B, Weigel D, Borgwardt K. 2016. easyGWAS: A Cloud-based Platform for Comparing the Results of Genome-wide Association Studies. Plant Cell. doi:I 0.I 105/tpc. I6.0055I

Hartzell C, Putzier I, Arreola J. 2005. Calcium-activated chloride channels. Annu Rev Physiol 67:719-758.

Hellens RP, Edwards EA, Leyland NR, Bean S, Mullineaux PM. 2000. pGreen: a versatile and flexible binary Ti vector for Agrobacterium-mediated plant transformation. Plant Mol Biol 42:819-832.

Hilleary R, Paez-Valencia J, Vens C, Toyota M, Palmgren M, Gilroy S. 2020. Tonoplast-localized Ca2+ pumps regulate $\mathrm{Ca} 2+$ signals during pattern-triggered immunity in Arabidopsis thaliana. Proc Natl Acad Sci U S A. doi:10.1073/pnas.2004183117

Hong YS, Park S, Geng C, Baek K, Bowman JD, Yoon J, Pak WL. 2002. Single amino acid change in the fifth transmembrane segment of the TRP Ca2+ channel causes massive degeneration of photoreceptors. J Biol Chem 277:33884-33889.

Huffer KE, Aleksandrova AA, Jara-Oseguera A, Forrest LR, Swartz KJ. 2020. Global alignment and assessment of TRP channel transmembrane domain structures to explore functional mechanisms. Elife 9. doi: $10.7554 /$ eLife. 58660

Hurni S, Brunner S, Stirnweis D, Herren G, Peditto D, Mclntosh RA, Keller B. 20I4. The powdery mildew resistance gene Pm8 derived from rye is suppressed by its wheat ortholog Pm3. Plant J 79:904-913.

Julius D. 2013. TRP channels and pain. Annu Rev Cell Dev Biol 29:355-384.

Jung C, Gené GG, Tomás M, Plata C, Selent J, Pastor M, Fandos C, Senti M, Lucas G, Elosua R, Valverde MA. 20II. A gain-of-function SNP in TRPC4 cation channel protects against myocardial infarction. Cardiovasc Res $91: 465-471$.

Kim HJ, Li Q, Tjon-Kon-Sang S, So I, Kiselyov K, Muallem S. 2007. Gain-of-function mutation in TRPML3 causes the mouse Varitint-Waddler phenotype. J Biol Chem 282:36I38-36I42.

Kover PX, Caicedo AL. 200I. The genetic architecture of disease resistance in plants and the maintenance of recombination by parasites. Mol Ecol I0:I-16.

Kremeyer B, Lopera F, Cox JJ, Momin A, Rugiero F, Marsh S, Woods CG, Jones NG, Paterson KJ, Fricker FR, Villegas A, Acosta N, Pineda-Trujillo NG, Ramírez JD, Zea J, Burley M-W, Bedoya G, Bennett DLH, Wood JN, Ruiz-Linares A. 2010. A gain-of-function mutation in TRPAI causes familial episodic pain syndrome. Neuron 66:67I-680.

Krogh A, Larsson B, von Heijne G, Sonnhammer EL. 200I. Predicting transmembrane protein topology with a hidden Markov model: application to complete genomes. J Mol Biol 305:567-580.

Lampropoulos A, Sutikovic Z, Wenzl C, Maegele I, Lohmann JU, Forner J. 2013. GreenGate - A Novel, Versatile, and Efficient Cloning System for Plant Transgenesis. PLoS One 8:e83043.

Landouré G, Zdebik AA, Martinez TL, Burnett BG, Stanescu HC, Inada H, Shi Y, Taye AA, Kong L, Munns $\mathrm{CH}$, Choo SS, Phelps CB, Paudel R, Houlden H, Ludlow CL, Caterina MJ, Gaudet R, Kleta R, Fischbeck $\mathrm{KH}$, Sumner CJ. 2010. Mutations in TRPV4 cause Charcot-Marie-Tooth disease type 2C. Nat Genet 42:170-174.

Lange H, Ndecky SYA, Gomez-Diaz C, Pflieger D, Butel N, Zumsteg J, Kuhn L, Piermaria C, Chicher J, Christie M, Karaaslan ES, Lang PLM, Weigel D, Vaucheret H, Hammann P, Gagliardi D. 2019. RSTI and RIPR connect the cytosolic RNA exosome to the Ski complex in Arabidopsis. Nat Commun 10:387I.

Lapin D, Bhandari DD, Parker JE. 2020. Origins and Immunity Networking Functions of EDSI Family Proteins. Annu Rev Phytopathol. doi:I0.I I 46/annurev-phyto-0 I0820-0I 2840

$\mathrm{Li} \mathrm{H}$, Durbin R. 2009. Fast and accurate short read alignment with Burrows-Wheeler transform. Bioinformatics 25:1754-1760.

Li H, Handsaker B, Wysoker A, Fennell T, Ruan J, Homer N, Marth G, Abecasis G, Durbin R, 1000 Genome Project Data Processing Subgroup. 2009. The Sequence Alignment/Map format and SAMtools. Bioinformatics 25:2078-2079.

Li J-F, Norville JE, Aach J, McCormack M, Zhang D, Bush J, Church GM, Sheen J. 20I3. Multiplex and homologous recombination-mediated genome editing in Arabidopsis and Nicotiana benthamiana using guide RNA and Cas9. Nat Biotechnol 3 I:688.

Li L, Habring A, Wang K, Weigel D. 2020. Atypical Resistance Protein RPW8/HR Triggers Oligomerization of the NLR Immune Receptor RPP7 and Autoimmunity. Cell Host Microbe. doi:10.1016/j.chom.2020.01.012

Lin Z, Chen Q, Lee M, Cao X, Zhang J, Ma D, Chen L, Hu X, Wang H, Wang X, Zhang P, Liu X, Guan L, Tang Y, Yang H, Tu P, Bu D, Zhu X, Wang K, Li R, Yang Y. 2012. Exome sequencing reveals mutations in TRPV3 as a cause of Olmsted syndrome. Am J Hum Genet 90:558-564.

Lishko PV, Procko E, Jin X, Phelps CB, Gaudet R. 2007. The ankyrin repeats of TRPVI bind multiple ligands and modulate channel sensitivity. Neuron 54:905-9/8. 
bioRxiv preprint doi: https://doi.org/10.1101/2021.01.25.428077; this version posted January $26,2021$. The copyright holder for this preprint (which was not certified by peer review) is the author/funder, who has granted bioRxiv a license to display the preprint in perpetuity. It is made available under aCC-BY 4.0 International license.

Li T, Natran A, Chen Y, Vercruysse J, Wang K, Gonzalez N, Dubois M, Inzé D. 2019. A genetics screen highlights emerging roles for CPL3, RSTI and URTI in RNA metabolism and silencing. Nat Plants 5:539550 .

Liu H, El Zein L, Kruse M, Guinamard R, Beckmann A, Bozio A, Kurtbay G, Mégarbané A, Ohmert I, Blaysat G, Villain E, Pongs O, Bouvagnet P. 2010. Gain-of-function mutations in TRPM4 cause autosomal dominant isolated cardiac conduction disease. Circ Cardiovasc Genet 3:374-385.

Loudet O, Gaudon V, Trubuil A, Daniel-Vedele F. 2005. Quantitative trait loci controlling root growth and architecture in Arabidopsis thaliana confirmed by heterogeneous inbred family. Theor Appl Genet I 1 0:742-753.

Lu H, Greenberg JT, Holuigue L. 2016. Editorial: Salicylic Acid Signaling Networks. Front Plant Sci 7:238.

Lu H, Liu Y, Greenberg JT. 2005. Structure-function analysis of the plasma membrane- localized Arabidopsis defense component ACD6. Plant J 44:798-809.

Lu H, Rate DN, Song JT, Greenberg JT. 2003. ACD6, a novel ankyrin protein, is a regulator and an effector of salicylic acid signaling in the Arabidopsis defense response. Plant Cell I 5:2408-2420.

Mackay TFC. 2014. Epistasis and quantitative traits: using model organisms to study gene-gene interactions. Nat Rev Genet 15:22-33.

Mah W, Sonkusare SK, Wang T, Azeddine B, Pupavac M, Carrot-Zhang J, Hong K, Majewski J, Harvey EJ, Russell L, Chalk C, Rosenblatt DS, Nelson MT, Séguin C. 2016. Gain-of-function mutation in TRPV4 identified in patients with osteonecrosis of the femoral head. J Med Genet 53:705-709.

Manolio TA, Collins FS, Cox NJ, Goldstein DB, Hindorff LA, Hunter DJ, McCarthy MI, Ramos EM, Cardon LR, Chakravarti A, Cho JH, Guttmacher AE, Kong A, Kruglyak L, Mardis E, Rotimi CN, Slatkin M, Valle D, Whittemore AS, Boehnke M, Clark AG, Eichler EE, Gibson G, Haines JL, Mackay TF, McCarroll SA, Visscher PM. 2009. Finding the missing heritability of complex diseases. Nature 46 I :747-753.

Ma W, Berkowitz GA. 2007. The grateful dead: calcium and cell death in plant innate immunity. Cell Microbiol 9:257I-2585.

Moeder W, Phan V, Yoshioka K. 2019. Ca2+ to the rescue - Ca2+channels and signaling in plant immunity. Plant Sci 279:19-26.

Myers BR, Bohlen CJ, Julius D. 2008a. A yeast genetic screen reveals a critical role for the pore helix domain in TRP channel gating. Neuron 58:362-373.

Myers BR, Saimi Y, Julius D, Kung C. 2008b. Multiple unbiased prospective screens identify TRP channels and their conserved gating elements. J Gen Physiol I 32:48I-486.

Nagata K, Zheng L, Madathany T, Castiglioni AJ, Bartles JR, García-Añoveros J. 2008. The varitint-waddler (Va) deafness mutation in TRPML3 generates constitutive, inward rectifying currents and causes cell degeneration. Proc Natl Acad Sci U S A 105:353-358.

Ng G, Seabolt S, Zhang C, Salimian S, Watkins TA, Lu H. 20I I. Genetic dissection of salicylic acid-mediated defense signaling networks in Arabidopsis. Genetics 189:85I-859.

Paaby AB, Rockman MV. 20I4. Cryptic genetic variation: evolution's hidden substrate. Nat Rev Genet I 5:247258.

Paulus JK, Kourelis J, Ramasubramanian S, Homma F, Godson A, Hörger AC, Hong TN, Krahn D, Ossorio Carballo L, Wang S, Win J, Smoker M, Kamoun S, Dong S, van der Hoorn RAL. 2020. Extracellular proteolytic cascade in tomato activates immune protease Rcr3. Proc Natl Acad Sci U S A I I7:1740917417.

Picelli S, Björklund AK, Reinius B, Sagasser S, Winberg G, Sandberg R. 2014 . Tn5 transposase and tagmentation procedures for massively scaled sequencing projects. Genome Res 24:2033-2040.

Pruitt RN, Zhang L, Saile SC, Karelina D, Fröhlich K, Wan W-L, Rao S, Gust AA, Locci F, Matthieu H A, Bart P H, Zhou J-M, Dangl JL, Weigel D, Parker JE, El Kasmi F, Nürnberger T. 2020. Arabidopsis cell surface LRR immune receptor signaling through the EDSI-PAD4-ADRI node. bioRxiv. doi:10.1101/2020.11.23.391516

Qi Z, Verma R, Gehring C, Yamaguchi Y, Zhao Y, Ryan CA, Berkowitz GA. 2010. Ca2+ signaling by plant Arabidopsis thaliana Pep peptides depends on AtPepRI, a receptor with guanylyl cyclase activity, and cGMP-activated Ca2+ channels. Proc Natl Acad Sci U S A 107:21 193-21 198.

Ramírez V, López A, Mauch-Mani B, Gil MJ, Vera P. 20I3. An extracellular subtilase switch for immune priming in Arabidopsis. PLoS Pathog 9:el 003445.

Rate DN, Cuenca JV, Bowman GR, Guttman DS, Greenberg JT. 1999. The gain-of-function Arabidopsis acd6 mutant reveals novel regulation and function of the salicylic acid signaling pathway in controlling cell death, defenses, and cell growth. Plant Cell I I:1695-I708.

R Core Team. 2019. R: A Language and Environment for Statistical Computing. 
bioRxiv preprint doi: https://doi.org/10.1101/2021.01.25.428077; this version posted January $26,2021$. The copyright holder for this preprint (which was not certified by peer review) is the author/funder, who has granted bioRxiv a license to display the preprint in perpetuity. It is made available under aCC-BY 4.0 International license.

Reichardt S, Repper D, Tuzhikov Al, Galiullina RA, Planas-Marquès M, Chichkova NV, Vartapetian AB, Stintzi A, Schaller A. 2018. The tomato subtilase family includes several cell death-related proteinases with caspase specificity. Sci Rep 8: I053I.

Reiser J, Polu KR, Möller CC, Kenlan P, Altintas MM, Wei C, Faul C, Herbert S, Villegas I, Avila-Casado C, McGee M, Sugimoto H, Brown D, Kalluri R, Mundel P, Smith PL, Clapham DE, Pollak MR. 2005. TRPC6 is a glomerular slit diaphragm-associated channel required for normal renal function. Nat Genet 37:739744.

Rowan BA, Seymour DK, Chae E, Lundberg DS, Weigel D. 2017. Methods for Genotyping-by-Sequencing. Methods Mol Biol 1492:22I-242.

Sali A, Blundell TL. 1993. Comparative protein modelling by satisfaction of spatial restraints. J Mol Biol 234:779-8I5.

Schaller A, Stintzi A, Rivas S, Serrano I, Chichkova NV, Vartapetian AB, Martínez D, Guiamét JJ, Sueldo DJ, van der Hoorn RAL, Ramírez V, Vera P. 2018. From structure to function - a family portrait of plant subtilases. New Phytol 21 8:90I-915.

Schrödinger LLC. 20I0. The PyMOL Molecular Graphics System, Version I.3rI.

Seybold H, Trempel F, Ranf S, Scheel D, Romeis T, Lee J. 2014. Ca2+ signalling in plant immune response: from pattern recognition receptors to Ca2+ decoding mechanisms. New Phytol 204:782-790.

Seyfferth C, Tsuda K. 2014. Salicylic acid signal transduction: the initiation of biosynthesis, perception and transcriptional reprogramming. Front Plant Sci 5:697.

Shimada TL, Shimada T, Hara-Nishimura I. 20I0. A rapid and non-destructive screenable marker, FAST, for identifying transformed seeds of Arabidopsis thaliana. Plant J 6I:519-528.

Soltis NE, Kliebenstein DJ. 2015. Natural Variation of Plant Metabolism: Genetic Mechanisms, Interpretive Caveats, and Evolutionary and Mechanistic Insights. Plant Physiol 169:1456-1468.

Stirnweis D, Milani SD, Brunner S, Herren G, Buchmann G, Peditto D, Jordan T, Keller B. 2014. Suppression among alleles encoding nucleotide-binding-leucine-rich repeat resistance proteins interferes with resistance in FI hybrid and allele-pyramided wheat plants. Plant J 79:893-903.

Straub T, Ludewig U, Neuhäuser B. 2017. The Kinase CIPK23 Inhibits Ammonium Transport in Arabidopsis thaliana. Plant Cell 29:409-422.

Sun X, Lapin D, Feehan JM, Stolze SC, Kramer K, Dongus JA, Rzemieniewski J, Blanvillain-Baufumé S, Harzen A, Bautor J, Derbyshire P, Menke FLH, Finkemeier I, Nakagami H, Jones JDG, Parker JE. 2020. Pathogen effector recognition-dependent association of NRGI with EDSI and SAGIOI in TNL receptor immunity. bioRxiv. doi:10.1101/2020.12.21.423810

Su Z, Zhou X, Haynes WJ, Loukin SH, Anishkin A, Saimi Y, Kung C. 2007. Yeast gain-of-function mutations reveal structure-function relationships conserved among different subfamilies of transient receptor potential channels. Proc Natl Acad Sci U S A I 04:19607-196I2.

Świadek M, Proost S, Sieh D, Yu J, Todesco M, Jorzig C, Rodriguez Cubillos AE, Plötner B, Nikoloski Z, Chae E, Giavalisco P, Fischer A, Schröder F, Kim S-T, Weigel D, Laitinen RAE. 2016. Novel allelic variants in ACD6 cause hybrid necrosis in local collection of Arabidopsis thaliana. New Phytol. doi:I0.1III/nph.14I55

Tamura K, Stecher G, Peterson D, Filipski A, Kumar S. 2013. MEGA6: Molecular Evolutionary Genetics Analysis version 6.0. Mol Biol Evol 30:2725-2729.

Tateda C, Zhang Z, Shrestha J, Jelenska J, Chinchilla D, Greenberg JT. 20I4. Salicylic acid regulates Arabidopsis microbial pattern receptor kinase levels and signaling. Plant Cell 26:4I7I-4I87.

Thor K, Jiang S, Michard E, George J, Scherzer S, Huang S, Dindas J, Derbyshire P, Leitão N, DeFalco TA, Köster P, Hunter K, Kimura S, Gronnier J, Stransfeld L, Kadota Y, Bücherl CA, Charpentier M, Wrzaczek M, MacLean D, Oldroyd GED, Menke FLH, Roelfsema MRG, Hedrich R, Feijó J, Zipfel C. 2020. The calcium-permeable channel OSCAI.3 regulates plant stomatal immunity. Nature. doi: 10.1038/s4I586-020-2702-I

Tian W, Hou C, Ren Z, Wang C, Zhao F, Dahlbeck D, Hu S, Zhang L, Niu Q, Li L, Staskawicz BJ, Luan S. 2019. A calmodulin-gated calcium channel links pathogen patterns to plant immunity. Nature. doi:I0.1038/s4I586-019-I4I3-y

Todesco M, Balasubramanian S, Hu TT, Traw MB, Horton M, Epple P, Kuhns C, Sureshkumar S, Schwartz C, Lanz C, Laitinen RAE, Huang Y, Chory J, Lipka V, Borevitz JO, Dangl JL, Bergelson J, Nordborg M, Weigel D. 2010. Natural allelic variation underlying a major fitness trade-off in Arabidopsis thaliana. Nature 465:632-636.

Todesco M, Kim S-T, Chae E, Bomblies K, Zaidem M, Smith LM, Weigel D, Laitinen RAE. 20I4. Activation of the Arabidopsis thaliana Immune System by Combinations of Common ACD6 Alleles. PLoS Genet 
bioRxiv preprint doi: https://doi.org/10.1101/2021.01.25.428077; this version posted January $26,2021$. The copyright holder for this preprint (which was not certified by peer review) is the author/funder, who has granted bioRxiv a license to display the preprint in perpetuity. It is made available under aCC-BY 4.0 International license.

\section{0:el 004459.}

Tran DTN, Chung E-H, Habring-Müller A, Demar M, Schwab R, DangI JL, Weigel D, Chae E. 20I7. Activation of a Plant NLR Complex through Heteromeric Association with an Autoimmune Risk Variant of Another NLR. Curr Biol 27: I |48-I I 60.

Van Hoeymissen E, Held K, Nogueira Freitas AC, Janssens A, Voets T, Vriens J. 2020. Gain of channel function and modified gating properties in TRPM3 mutants causing intellectual disability and epilepsy. Elife 9. doi: $10.7554 /$ eLife.57190

van Wersch R, Li X, Zhang Y. 2016. Mighty Dwarfs: Arabidopsis Autoimmune Mutants and Their Usages in Genetic Dissection of Plant Immunity. Front Plant Sci 7:1717.

Vasseur F, Fouqueau L, de Vienne D, Nidelet T, Violle C, Weigel D. 2019. Nonlinear phenotypic variation uncovers the emergence of heterosis in Arabidopsis thaliana. PLoS Biol I7:e30002 |4.

Venkatachalam K, Montell C. 2007. TRP channels. Annu Rev Biochem 76:387-4I7.

Vlot AC, Dempsey DA, Klessig DF. 2009. Salicylic Acid, a multifaceted hormone to combat disease. Annu Rev Phytopathol 47: I77-206.

Vo KTX, Kimauthor C-Y, Chandranauthor AKN, Jungauthor K-H, Anauthor G, Jeonauthor J-S. 2015. Molecular insights into the function of ankyrin proteins in plants. doi: 10.1007/s I2374-015-0228-0

Wang G, Wang K. 2017. The Ca2+-Permeable Cation Transient Receptor Potential TRPV3 Channel: An Emerging Pivotal Target for Itch and Skin Diseases. Mol Pharmacol 92: 193-200.

Wang H, Xu Z, Lee BH, Vu S, Hu L, Lee M, Bu D, Cao X, Hwang S, Yang Y, Zheng J, Lin Z. 2019. Gain-ofFunction Mutations in TRPM4 Activation Gate Cause Progressive Symmetric Erythrokeratodermia. J Invest Dermatol I39:1089-1097.

Wang J, Hu M, Wang J, Qi J, Han Z, Wang G, Qi Y, Wang H-W, Zhou J-M, Chai J. 20 I9. Reconstitution and structure of a plant NLR resistosome conferring immunity. Science 364:eaav5870.

Waterhouse AM, Procter JB, Martin DMA, Clamp M, Barton GJ. 2009. Jalview Version 2--a multiple sequence alignment editor and analysis workbench. Bioinformatics 25:II89-II91.

Winn MP, Conlon PJ, Lynn KL, Farrington MK, Creazzo T, Hawkins AF, Daskalakis N, Kwan SY, Ebersviller S, Burchette JL, Pericak-Vance MA, Howell DN, Vance JM, Rosenberg PB. 2005. A mutation in the TRPC6 cation channel causes familial focal segmental glomerulosclerosis. Science 308:1801-1804.

Winter D, Vinegar B, Nahal H, Ammar R, Wilson GV, Provart NJ. 2007. An "Electronic Fluorescent Pictograph" browser for exploring and analyzing large-scale biological data sets. PLoS One 2:e7I8.

Wróblewski T, Spiridon L, Martin EC, Petrescu A-J, Cavanaugh K, Jose-Truco M, Xu H, Gozdowski D, Pawłowski K, Michelmore RW, Takken FLW. 2018. Genome-wide functional analyses of plant coiledcoil NLR-type pathogen receptors reveal essential roles of their $\mathrm{N}$-terminal domain in oligomerization, networking, and immunity. PLoS Biol 16:e200582I.

Wu C-H, Abd-El-Haliem A, Bozkurt TO, Belhaj K, Terauchi R, Vossen JH, Kamoun S. 20I7. NLR network mediates immunity to diverse plant pathogens. Proc Natl Acad Sci U S A I I 4:8I I3-8I I8.

Wu R, Lucke M, Jang Y-T, Zhu W, Symeonidi E, Wang C, Fitz J, Xi W, Schwab R, Weigel D. 20I8. An efficient CRISPR vector toolbox for engineering large deletions in Arabidopsis thaliana. Plant Methods I4:65.

Wu Z, Li M, Dong OX, Xia S, Liang W, Bao Y, Wasteneys G, Li X. 2019. Differential regulation of TNLmediated immune signaling by redundant helper CNLs. New Phytol 222:938-953.

Xu H, Delling M, Li L, Dong X, Clapham DE. 2007. Activating mutation in a mucolipin transient receptor potential channel leads to melanocyte loss in varitint-waddler mice. Proc Natl Acad Sci U S A I 04: I 832 I18326.

Yang Y, Zhang Y, Ding P, Johnson K, Li X, Zhang Y. 20I2. The ankyrin-repeat transmembrane protein BDAI functions downstream of the receptor-like protein SNC2 to regulate plant immunity. Plant Physiol I 59:1857-1865.

Zhang Z, Guo J, Zhao Y, Chen J. 2019. Identification and characterization of maize ACD6-like gene reveal ZmACD6 as the maize orthologue conferring resistance to Ustilago maydis. Plant Signal Behav I 4:e 1651604.

Zhang Z, Shrestha J, Tateda C, Greenberg JT. 20I4. Salicylic acid signaling controls the maturation and localization of the arabidopsis defense protein ACCELERATED CELL DEATH6. Mol Plant 7:I365-I383.

Zhang Z, Tateda C, Jiang S-C, Shrestha J, Jelenska J, Speed DJ, Greenberg J. 20I7. A suite of receptor-like kinases and a putative mechano-sensitive channel are involved in autoimmunity and plasma membranebased defenses in Arabidopsis. Mol Plant Microbe Interact. doi: 10.1094/MPMI-09-16-0I84-R

Zhu W, Zaidem M, Van de Weyer A-L, Gutaker RM, Chae E, Kim S-T, Bemm F, Li L, Todesco M, Schwab R, Unger F, Beha MJ, Demar M, Weigel D. 2018. Modulation of ACD6 dependent hyperimmunity by natural alleles of an Arabidopsis thaliana NLR resistance gene. PLoS Genet I 4:e I007628. 
bioRxiv preprint doi: https://doi.org/10.1101/2021.01.25.428077; this version posted January 26, 2021. The copyright holder for this preprint (which was not certified by peer review) is the author/funder, who has granted bioRxiv a license to display the preprint in perpetuity. It is made available under aCC-BY 4.0 International license.

Zimmermann L, Stephens A, Nam S-Z, Rau D, Kübler J, Lozajic M, Gabler F, Söding J, Lupas AN, Alva V. 2018. A Completely Reimplemented MPI Bioinformatics Toolkit with a New HHpred Server at its Core. J Mol Biol 430:2237-2243. 
bioRxiv preprint doi: https://doi.org/10.1101/2021.01.25.428077; this version posted January 26, 2021. The copyright holder for this preprint (which was not certified by peer review) is the author/funder, who has granted bioRxiv a license to display the preprint in perpetuity. It is made available under aCC-BY 4.0 International license.

\section{Figure Supplements}

A
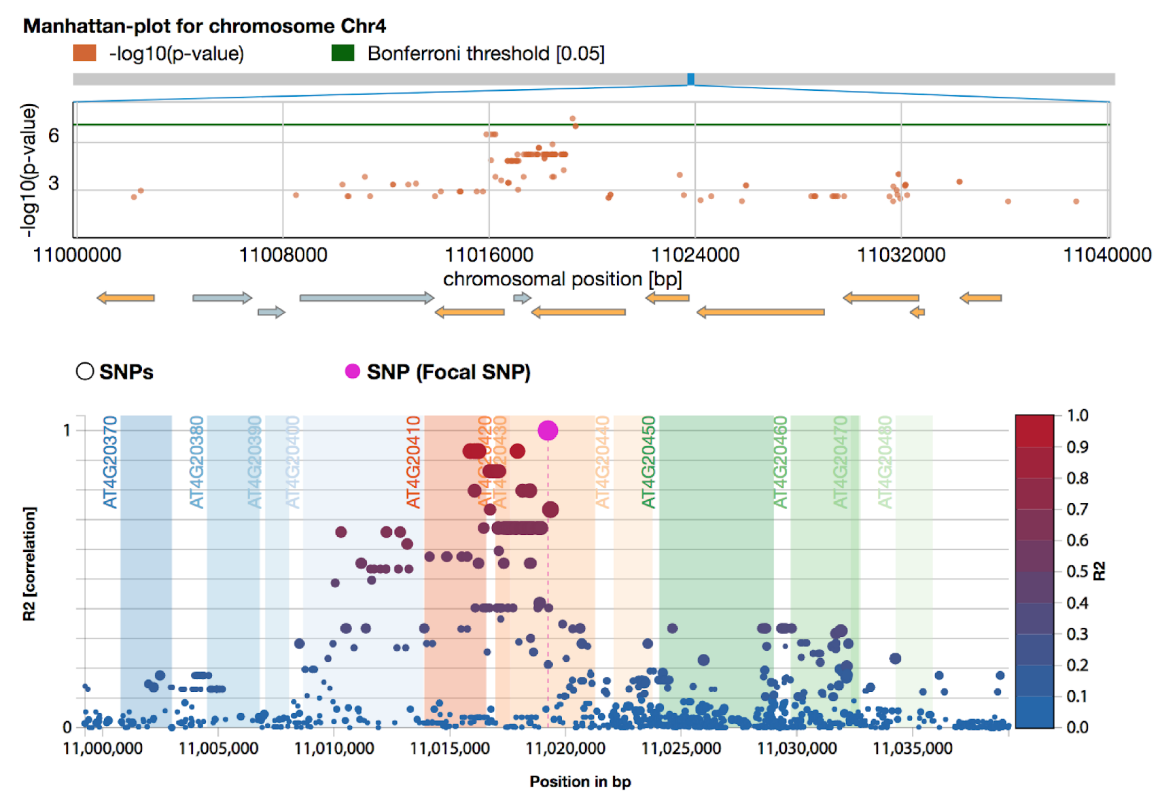

B

Manhattan-plot for chromosome Chr1

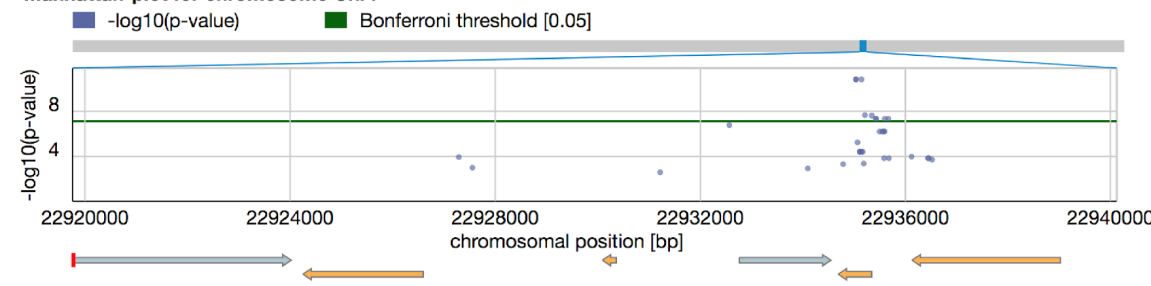

OSNPs $\quad$ SNP (Focal SNP)

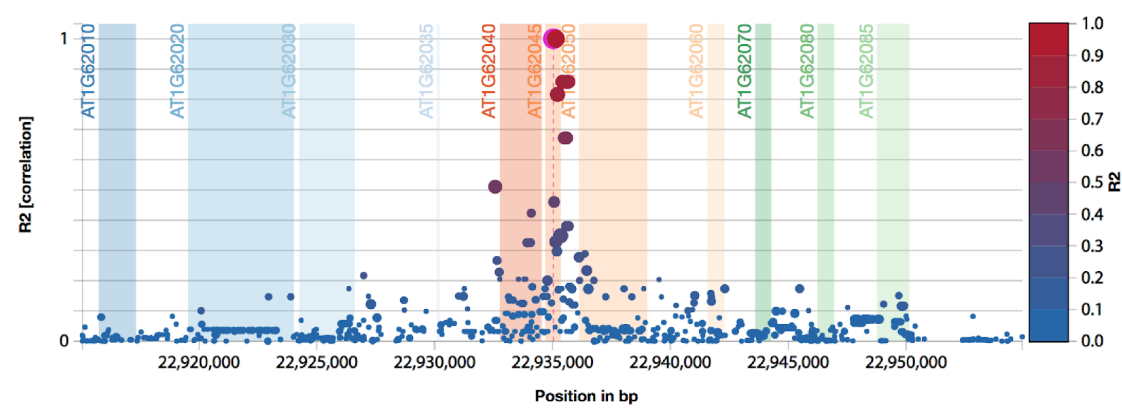

Figure I-figure supplement I. GWA of leaf necrosis. (A) Top: Genomic region surrounding significant GWA peak for leaf necrosis on chromosome 4 (MHA2). Bottom: Linkage disequilibrium ( $\left.r^{2}\right)$ of SNPs surrounding MHA2. (B) Top: Genomic region surrounding significant GWA peak for leaf necrosis on chromosome I (MHAI). Bottom: LD of SNPs surrounding MHAI. 


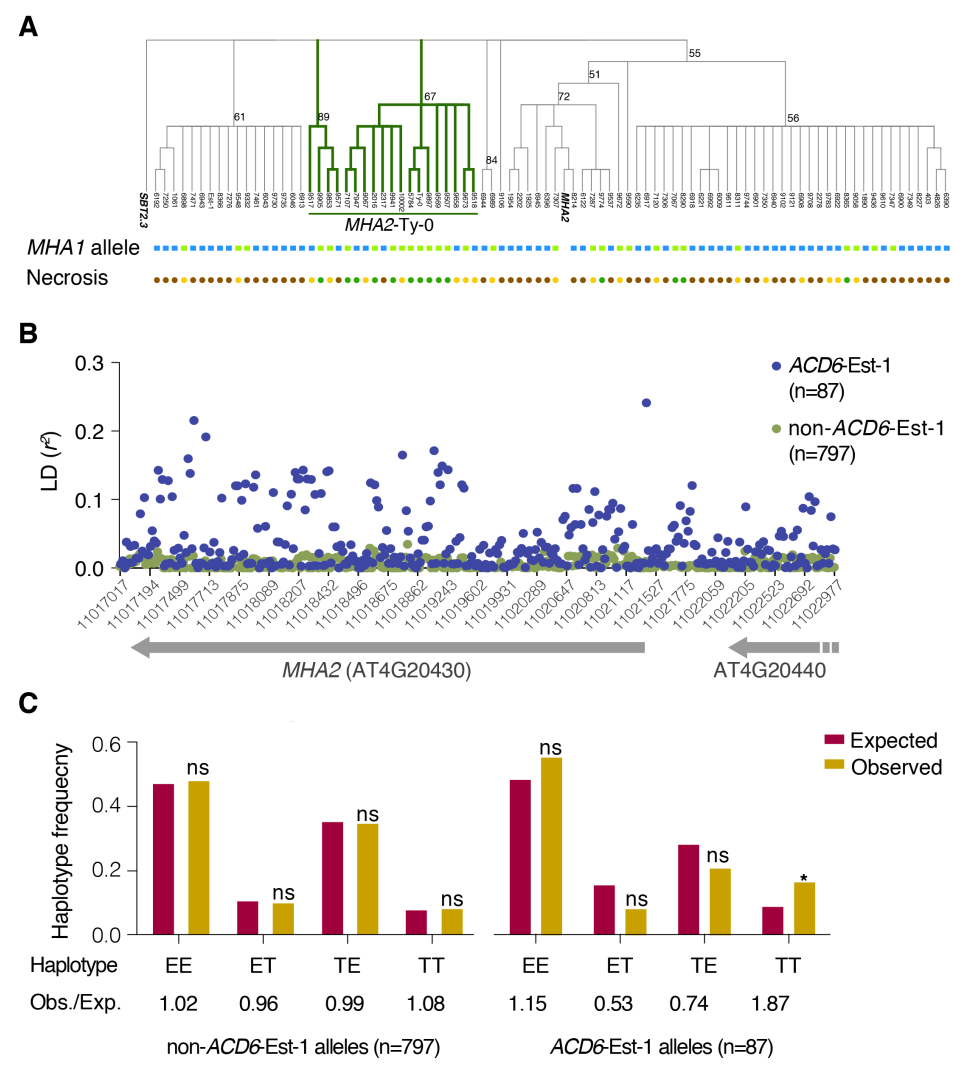

Figure I-figure supplement 2. Linkage between ACD6-Est-I and different alleles at MHAI and MHA2. (A) Condensed phylogenetic tree (50\% bootstrap cut-off value) using maximum likelihood constructed from phylogeny of MHA2 DNA sequences from 87 accessions with the ACD6-Est-I allele, together with MHA2 (SBT2.2) and its closest homolog SBT2.3 from the Col-0 reference genome. Bootstrap values over $50 \%$ are indicated at the main branches. Below, MHAI allele types in these 87 accessions are presented as light blue (MHAI-Est-I) and light green (MHAI-Ty-0). Leaf necrosis is indicated as green (weak), orange (intermediate), and brown (severe). The MHA2-Ty-0 clade is indicated in dark green. (B) Linkage disequilibrium between the causal SNP from MHAI (Chrl: 22935037) and SNPs across the MHA2 locus in 87 ACD6-Est-I and 797 non-ACD6-Est-I accessions. The values of $r^{2}$ are statistically significantly different for the two groups ( $p<0.000$ I, Wilcoxon nonparametric test). (C) Frequency of haplotypes with different MHAI and MHA2 alleles in two populations with ACD6-Est-I and other ACD6 alleles. The differences between expected and observed haplotype combinations were analyzed by binomial tests for each haplotype; ns, not significant at $p>0.05$, asterisk: $p=0.006$ (Bonferroni adjusted). The first letter indicates MHAI allele type, the second MHA2 allele type. E, Est-I type, T, Ty-0 type. 
A

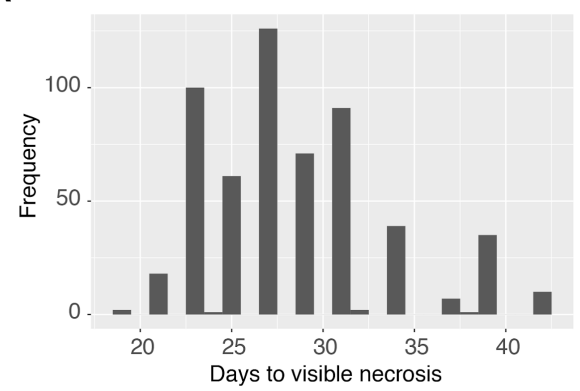

C

$\begin{array}{lrcc}\text { Chromosome } 1 & & 22.1 & 23.6 \mathrm{Mb} \\ & & \downarrow & \downarrow \\ \mathrm{HIF} \mathrm{F} & & 532 & 542 \\ \mathrm{p}=0 & \text { Ty-0/Ty-0 } & 527 & 505 \\ & \text { Ty-0/Est-1 } & 98 & 102 \\ & \text { Est-1/Est-1 } & & \\ & & & \\ \mathrm{HIFF}_{\mathrm{p}=0} & \text { Ty-0/Ty-0 } & 102 & 110 \\ & \text { Ty-0/Est-1 } & 79 & 77 \\ & \text { Est-1/Est-1 } & 3 & 3\end{array}$

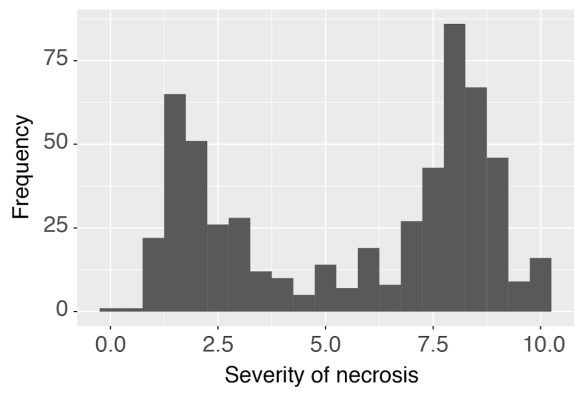

D
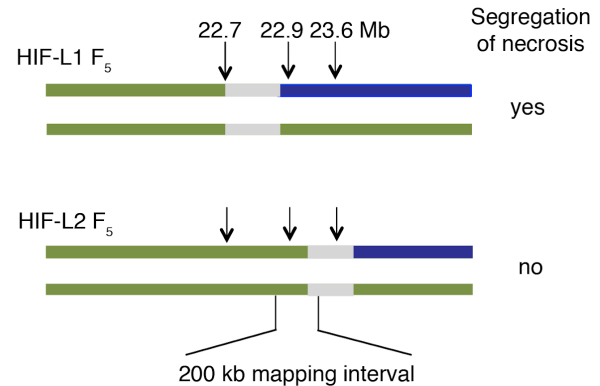

no

Figure I-figure supplement 3. QTL analysis and fine-mapping. (A) Distribution of days to visible necrosis in $798 F_{2}$ individuals from Est-I $\times$ Ty-0 cross. (B) Distribution of subjective severity of necrosis in the same $F_{2}$ population as (A). (C) Co-segregation of SSLP markers surrounding MHAI and absence of leaf necrosis in a Heterogeneous Inbred Family (HIF) in $F_{3}$ and $F_{6}$ generations. In the $F_{3}$ generation, fewer than $10 \%$ of individuals without leaf necrosis are fixed for Est- $I$ alleles at the two markers indicated on top. In the $F_{6}$ generation, it is fewer than $2 \%$. $p$-values from $\chi^{2}$ test indicate differences among genotypic classes (Est- I/Est-I v. Ty-0/Ty-0 or Ty0/Est-I at both markers). (D) Segregation of leaf necrosis in two HIF lines, differing at MHAI locus. 
A

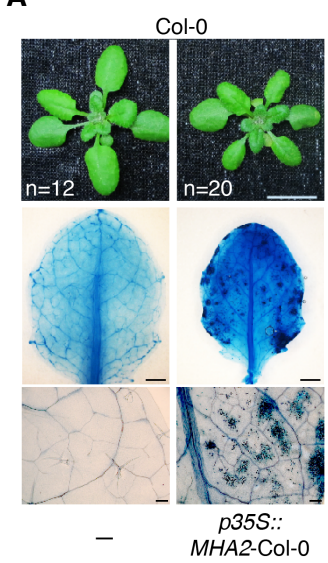

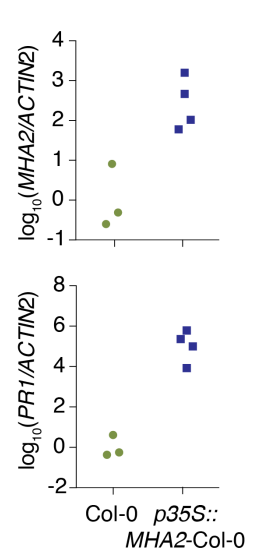

C

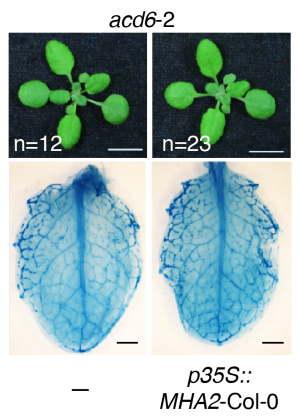

Figure I-figure supplement 4. Identification of MHA2 as a genetic modifier of ACD6-Est- I. (A) Necrotic leaf phenotype induced by overexpression of MHA2 (SBT2.2) from CaMV 35S promoter. Top, T, transformants expressing p35S::MHA2-Col-0 in Col-0 background. Representatives of plants without (left) and with (right) the transgene. Middle and bottom, Trypan Blue-stained fifth leaves (entire leaves and close ups). Scale bars, I cm (top), I mm (middle), $0.1 \mathrm{~mm}$ (bottom). (B) Accumulation of MHA2 and PRI mRNA, as measured by qRT-PCR from

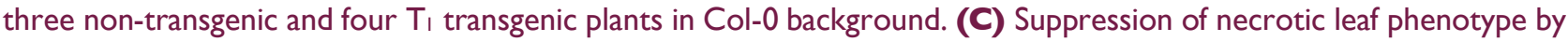
acd6-2 loss-of-function allele. Top, TI transformants expressing p35S::MHA2-Col-0. Representatives of plants without (left) and with (right) the transgene in an acd6-2 background. Bottom, Trypan Blue-stained fifth leaves (entire leaves). Scale bars, I cm (top), I mm (bottom). 
bioRxiv preprint doi: https://doi.org/10.1101/2021.01 25.428077; this version posted January 26, 2021. The copyright holder for this preprint (which was not certified by peer review) is the author/funder, who has granted bioRxiv a license to display the preprint in perpetuity. It is made available under aCC-BY 4.0 International license.

A

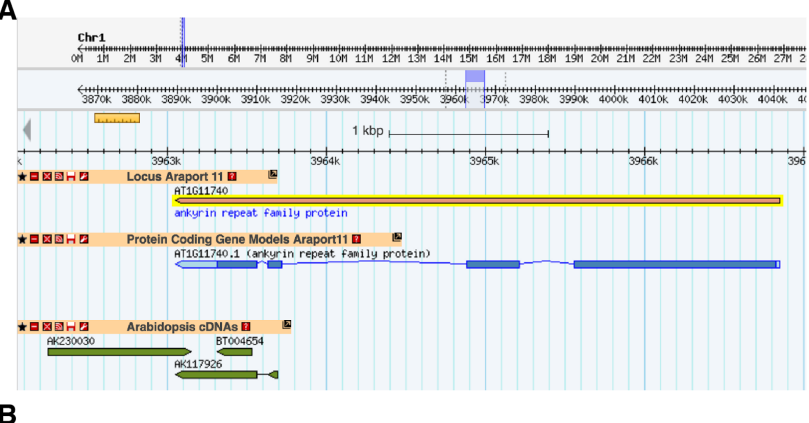

B

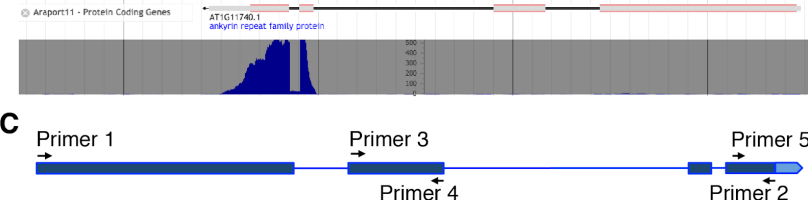

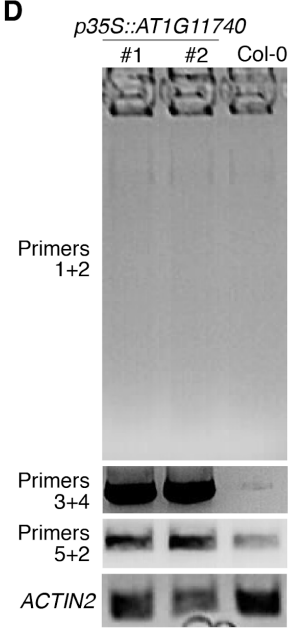

E
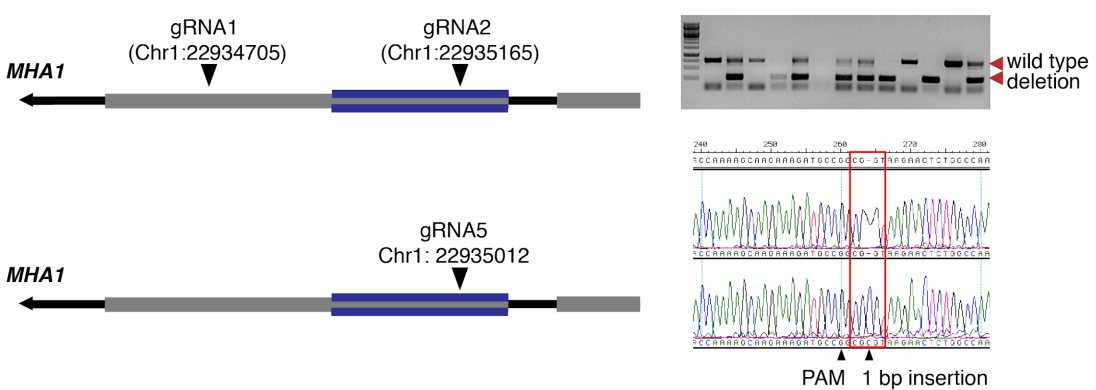

$\mathbf{F}$
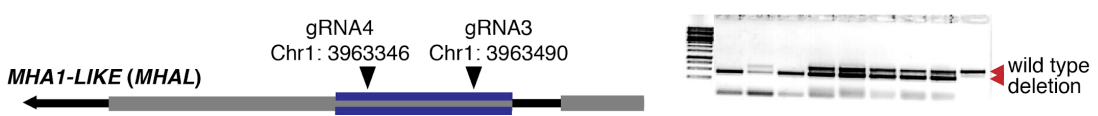

Figure 2-figure supplement I. MHAI-LIKE (MHAL) locus and generation of $\mathrm{mhal}$ and $\mathrm{mhal}$ mutants. (A) Annotation of ATIGII740 gene model in Araport II. (B) RNA-seq data from light-grown seedlings indicate very different coverages of the 5' and 3' ends of the annotated ATIGII740 gene model. (C, D) RT-PCR analysis of Col-0 transformant overexpressing the annotated ATIGII740 gene model. Full-length ATIGII740 cDNA (primers $1+2$ ) cannot be amplified from $\mathrm{T}_{2}$ transgenic plants or Col-0 plants. A 5' product (primers 3+4) overaccumulates in $T_{2}$ transgenic plants, while a 3' product (primers 5+2) accumulates to somewhat higher levels in transgenic compared to Col-0 non-transgenic plants. (E) CRISPR-Cas9-induced mhal alleles. Left, gRNA positions. Right, genotyping by PCR (top) or Sanger sequencing (bottom). (F) CRISPR-Cas9-induced mhal alleles in Ty-0. Left, gRNA positions. Right, genotyping by PCR. 
bioRxiv preprint doi: https://doi.org/10.1101/2021.01.25.428077; this version posted January 26, 2021. The copyright holder for this preprint (which was not certified by peer review) is the author/funder, who has granted bioRxiv a license to display the preprint in perpetuity. It is made available under aCC-BY 4.0 International license.

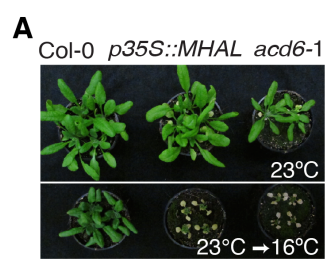

C

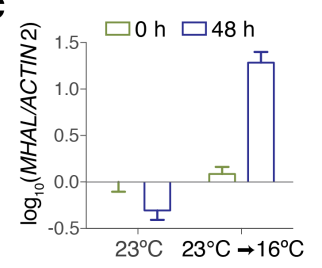

B

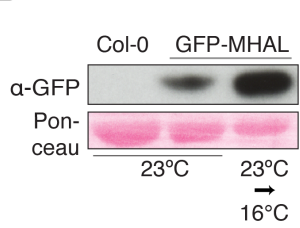

D

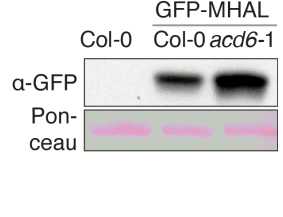

E

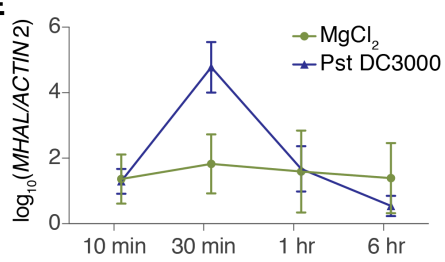

Figure 3-figure supplement I. MHAL acts as a feedforward regulator of ACD6. (A) Temperaturedependent phenotypes of $p 35$ S.:GFP-MHAL and acd6-I plants. Top, 3-week-old plants grown in $23^{\circ} \mathrm{C}$ long days. Bottom, plants grown for 10 days in $23^{\circ} \mathrm{C}$ long days and then moved to $16^{\circ} \mathrm{C}$ for 10 days. (B) GFP-MHAL protein accumulation in two-week old plants in Col- 0 background grown in $23^{\circ} \mathrm{C}$ long days or plants grown in $23^{\circ} \mathrm{C}$ long days for 12 days, then moved to $16^{\circ} \mathrm{C}$ for 2 days. (C) Accumulation of MHAL mRNA, as measured by qRT-PCR, in non-transgenic twoweek old acd6-I plants grown in $23^{\circ} \mathrm{C}$ long days, or plants grown in $23^{\circ} \mathrm{C}$ long days for 12 days, then moved to $16^{\circ} \mathrm{C}$ for 2 days. (D) GFP-MHAL protein accumulation in Col-0 and acd6-I backgrounds at $16^{\circ} \mathrm{C}$. Plants were from a segregating $\mathrm{F}_{2}$ population, and $\mathrm{I} 5$ individuals each were pooled for protein blot analysis at an early time point. (E) Time course of MHAL mRNA accumulation, as measured by $\mathrm{qRT}-\mathrm{PCR}$, in Col-0 plants after infiltration with Pseudomonas syringae pv. tomato DC3000 (OD $600=0.3)$. 
bioRxiv preprint doi: $\mathrm{https}$ //doi.org/10.1101/2021.01.25.428077; this version posted January 26,2021 . The copyright holder for this preprint (which was not certified by peer review) is the author/funder, who has granted bioRxiv a license to display the preprint in perpetuity. It is made available under aCC-BY 4.0 International license.

A
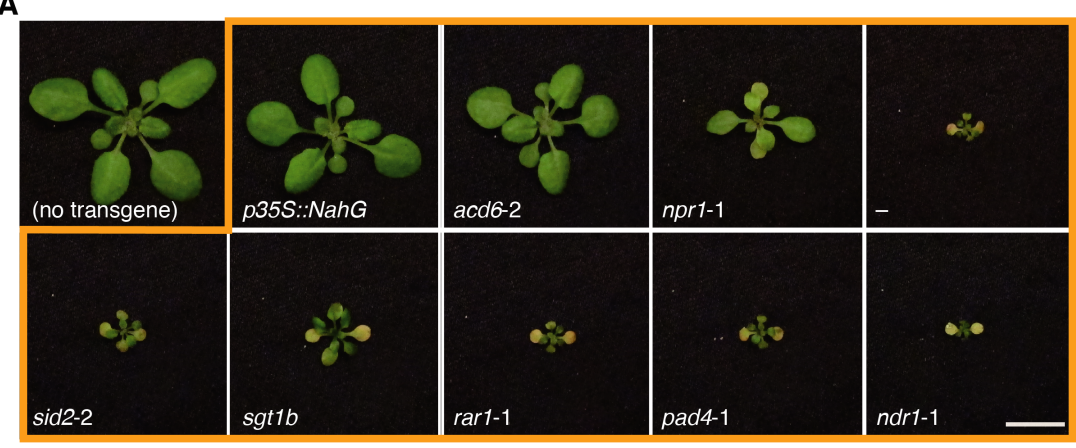

B

C
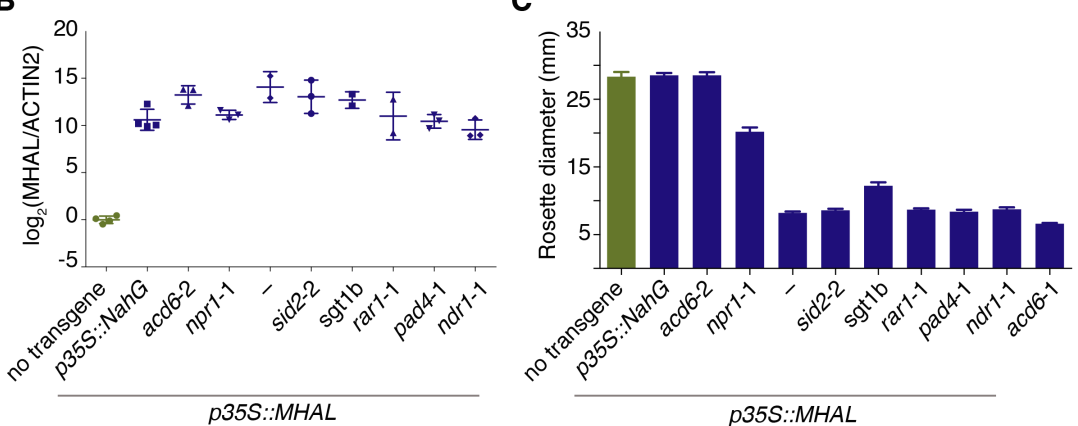

Figure 3-figure supplement 2. Genetic requirement of immune signaling components for MHALinduced necrosis and dwarfism. (A) Representative p35s::MHAL $T_{2}$ transformants in different backgrounds (thick orange boundary), with non-transgenic Col-0 as control on the top left. Plants were grown at $16^{\circ} \mathrm{C}$. (B) Accumulation of MHAL mRNA in $\mathrm{T}_{2}$ transformants, as measured by qRT-PCR from three biological replicates each. (C) Rosette diameter of $T_{2}$ transformants. At least 15 plants were used for each measurement. acd6-I for comparison. 
bioRxiv preprint doi: https://doi.org/10.1101/2021.01.25.428077; this version posted January 26, 2021. The copyright holder for this preprint (which was not certified by peer review) is the author/funder, who has granted bioRxiv a license to display the preprint in perpetuity. It is made available under aCC-BY 4.0 International license.

A

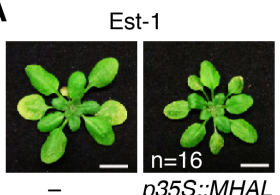

B

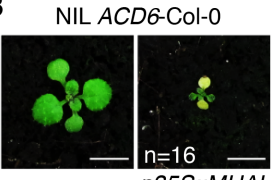

NIL $A C D 6$-Est-1

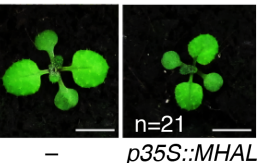

Figure 3-figure supplement 3. MHAL activity is ACD6 allele dependent. 4-week old $p 355$ :::MHAL T, transformants grown under $16^{\circ} \mathrm{C}$ long day are shown next to non-transgenic controls. (A) The effects of $p 35 \mathrm{~S}:: \mathrm{MHAL}$ are suppressed in an Est-I background. Compare to Figure 3B. (B) The effects of $p 35$ S::MHAL are apparent in a NIL (Todesco et al., 20I0) with the ACD6-Col-0 allele, but not in a NIL with the ACD6-Est-I allele. 
bioRxiv preprint doi: https://doi.org/10.1101/2021.01.25.428077; this version posted January 26, 2021. The copyright holder for this preprint (which was not certified by peer review) is the author/funder, who has granted bioRxiv a license to display the preprint in perpetuity. It is made available under aCC-BY 4.0 International license.
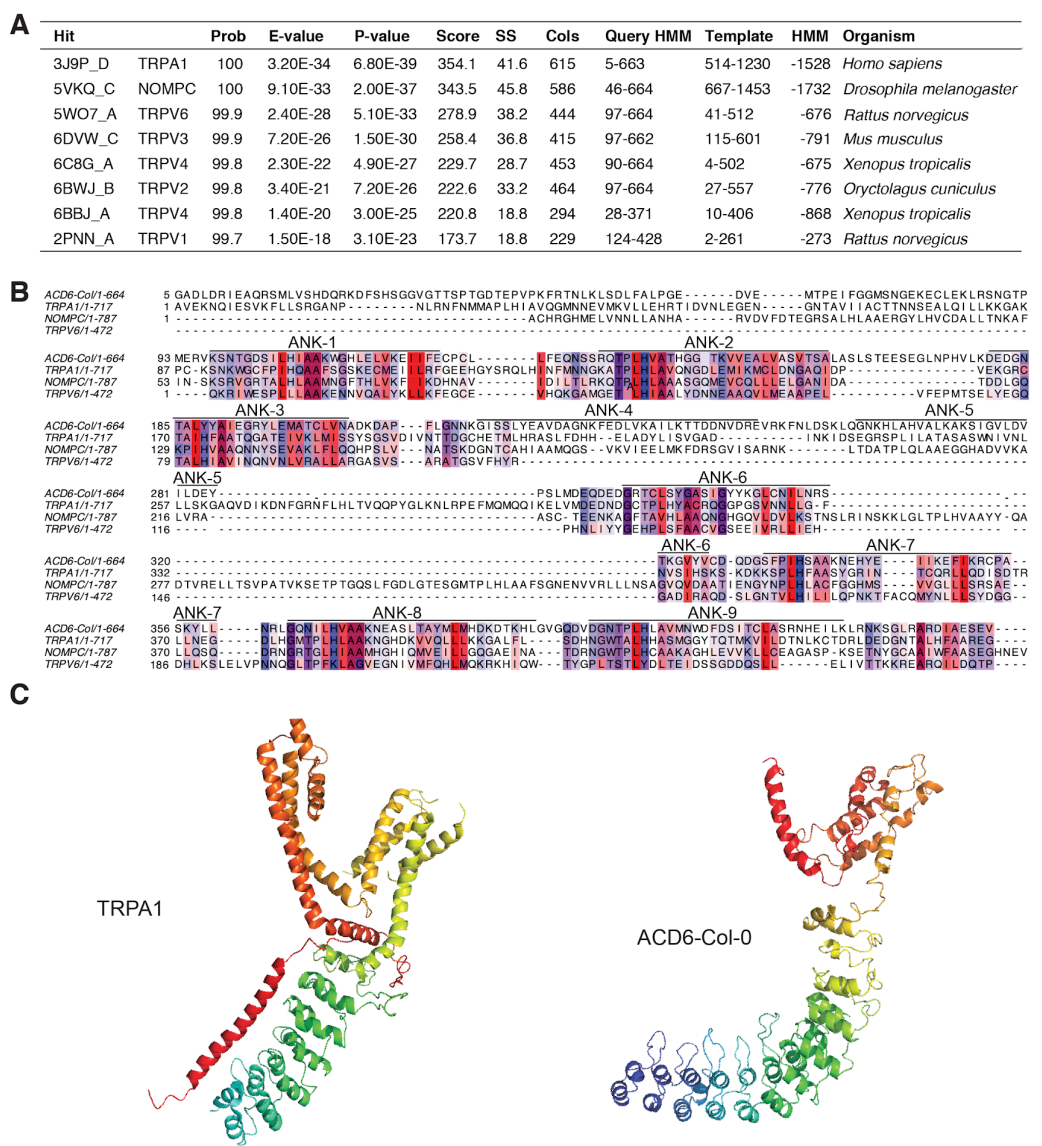

Figure 5-figure supplement I. Homology modeling of ACD6. (A) HHPred hits with ACD6-Col-0 as query. (B) Protein sequence alignment of ankyrin (ANK) repeats of ACD6-Col-0, fly NOMPC, human TRPAI and rat TRPV6. Coloring indicates hydropathy index. (C) Structure of TRPAI compared to homology modeled ACD6 using Modeller with 2PNN_A, 3J9P_D, 5W07_A, 5VKQ_C, 6DVW_C and 6BBJ_A as templates. Structures are colored from $N$ to $C$ terminus (blue to red). Note that the $C$-terminal portion of the ACD6 model shows only limited similarity to the TRPAI pore. 
bioRxiv preprint doi: https://doi.org/10.1101/2021.01.25.428077; this version posted January 26, 2021. The copyright holder for this preprint (which was not certified by peer review) is the author/funder, who has granted bioRxiv a license to display the preprint in perpetuity. It is made available under aCC-BY 4.0 International license.

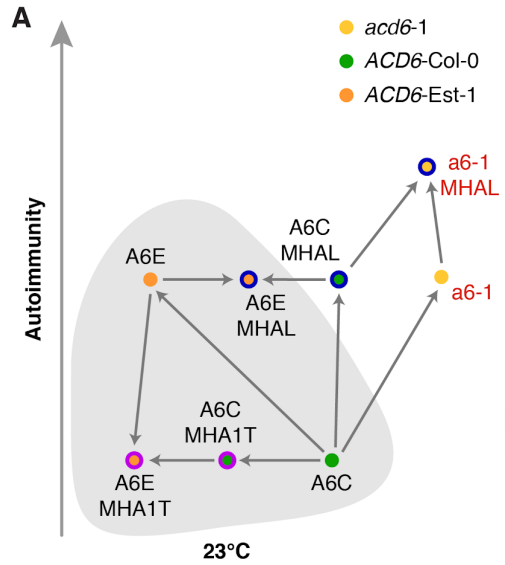

\section{O 035 :::MHAL}

$$
\text { O } \mathrm{P} 35 \mathrm{~S}: \mathrm{:MHA1-Ty-0}
$$

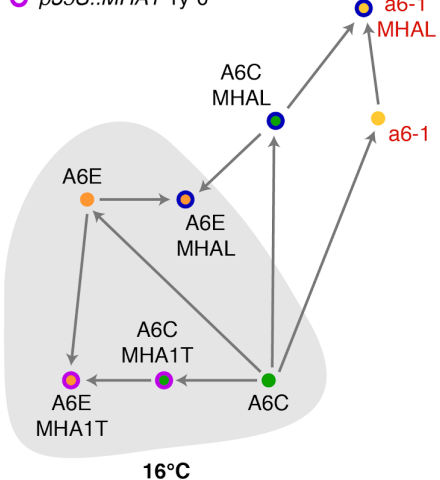

B

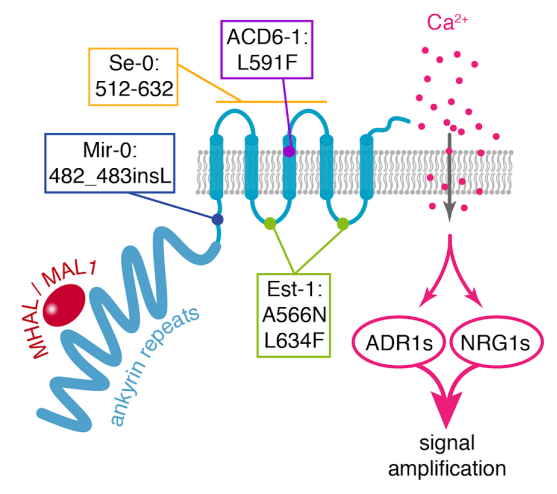

Figure 5-figure supplement 2. Interactions of MHAI, MHAL and ACD6. (A) Summary of genetic interactions between MHAI, MHAL and ACD6. Each arrow denotes a single genetic change. Temperature-insensitive genotypes on top of grey background. The temperature-sensitivity is potentially due to MHAL RNA in a wild-type background accumulating to higher levels at $16^{\circ} \mathrm{C}$, and also MHAL protein accumulating to higher levels at $16^{\circ} \mathrm{C}$, even when expressed from a constitutive promoter. Combinations with the induced allele acd6-I in red. (B) Biochemical model for ACD6 function. ACD6 facilitates calcium influx, either by regulating ion channels or acting as an ion channel itself, and its activity is enhanced either by binding of MHAL to its ankyrin repeats, or by mutations in the transmembrane domains. MHAI-Ty-0 can suppress the activity of ACD6-Est-I. Locations of changes in induced and natural gain-offunction alleles are indicated. 


\section{Tables}

Table I. Necrosis scores in six individuals each of accessions with ACD6-Est-I-like alleles.

\begin{tabular}{|c|c|c|c|c|c|c|c|c|c|c|}
\hline $\begin{array}{c}\text { Accession ID } \\
\text { (1001G) }\end{array}$ & Name & Country & Latitude & Longitude & \multicolumn{6}{|c|}{$\begin{array}{l}\text { Necrosis } \\
\text { severity }\end{array}$} \\
\hline 403 & Zdarec3 & CZE & 49.3667 & 16.2667 & 5 & 55 & 55 & 55 & 5 & 5 \\
\hline 1061 & Brösarp-II-I35 & SWE & 55.7167 & 14.1333 & 4 & 32 & 45 & 54 & 4 & 4 \\
\hline 1890 & MNF-Riv-2I & USA & 43.5139 & -86.1859 & 5 & 55 & 55 & 55 & 5 & 5 \\
\hline 1925 & MNF-Che-2 & USA & $43.525 I$ & -86.1843 & 5 & 55 & 55 & 55 & 5 & 5 \\
\hline 1954 & MNF-Jac- 12 & USA & 43.5187 & -86.1739 & 5 & 55 & 55 & 55 & 5 & 5 \\
\hline 2016 & MNF-Pin-39 & USA & 43.5356 & -86.1788 & 2 & 2 & 13 & 32 & 2 & 2 \\
\hline 2202 & Pent-23 & USA & 43.7623 & -86.3929 & 5 & 55 & 55 & 55 & 5 & 5 \\
\hline 2278 & SLSP-35 & USA & 43.665 & -86.496 & 5 & 55 & 55 & 55 & 5 & 5 \\
\hline 2317 & Ste-40 & USA & 42.03 & $-86.5 \mid 4$ & 4 & 42 & 43 & 35 & 5 & 4 \\
\hline 4826 & UKSW06-226 & UK & 50.4 & -4.9 & 5 & 5 & 55 & 5 & 5 & 5 \\
\hline 5784 & Ty-I & UK & 56.4 & -5.2 & 2 & 2 & 23 & 3 & 2 & 2 \\
\hline 6009 & Eden-I & SWE & 62.877 & 18.177 & 5 & 5 & 55 & 55 & 5 & 5 \\
\hline 6043 & Löv-I & SWE & 62.801 & 18.079 & 5 & 5 & 55 & 55 & 5 & 5 \\
\hline 6046 & Löv-5 & SWE & 62.801 & 18.079 & 5 & 5 & 55 & 55 & 5 & 5 \\
\hline 6122 & T670 & SWE & 55.8364 & 13.3075 & 3 & 32 & 2 & 4 & 3 & 3 \\
\hline 6192 & TDr-5 & SWE & 55.7692 & 14.1369 & 4 & 4 & 45 & 53 & 3 & 4 \\
\hline 6221 & TGR 02 & SWE & 62.806 & 18.1896 & 5 & 5 & 55 & 5 & 5 & 5 \\
\hline 6235 & TOM 01 & SWE & 62.9611 & 18.3589 & 5 & 5 & 55 & 55 & 5 & 5 \\
\hline 6390 & Udul 3-36 & CZE & 49.277 I & $16.63 \mid 4$ & 5 & 5 & 55 & 55 & 5 & 5 \\
\hline 6396 & Udul 4-9 & CZE & 49.2771 & 16.6314 & 5 & 5 & 55 & 5 & 5 & 5 \\
\hline 6898 & An-I & BEL & 51.2167 & 4.4 & 3 & 3 & 33 & 3 & 3 & 3 \\
\hline 6900 & Bil-5 & SWE & 63.324 & 18.484 & 5 & 5 & 55 & 5 & 5 & 5 \\
\hline 6901 & Bil-7 & SWE & 63.324 & 18.484 & 5 & 5 & 55 & 5 & 5 & 5 \\
\hline 6908 & CIBC-5 & UK & 51.4083 & -0.6383 & 3 & 2 & 42 & 2 & 4 & 3 \\
\hline 6913 & Eden-2 & SWE & 62.877 & 18.177 & 5 & 5 & 5 & 5 & 5 & 5 \\
\hline 6917 & Fäb-2 & SWE & 63.0165 & 18.3174 & 4 & 4 & 4 & 3 & 4 & 5 \\
\hline 6918 & Fäb-4 & SWE & 63.0165 & 18.3174 & 4 & 4 & 4 & 4 & 4 & 4 \\
\hline 6922 & Gu-0 & GER & 50.3 & 8 & 3 & 2 & 3 & 4 & 3 & 3 \\
\hline 6940 & $M z-0$ & GER & 50.3 & 8.3 & 5 & 5 & 5 & 5 & 5 & 5 \\
\hline 6943 & NFA-IO & UK & 51.4083 & -0.6383 & 4 & 3 & 4 & 4 & 5 & 4 \\
\hline 6944 & NFA-8 & UK & 51.4083 & -0.6383 & 5 & 5 & 5 & 5 & 5 & 4 \\
\hline 6945 & Nok-3 & NED & 52.24 & 4.45 & 4 & 3 & 5 & 4 & 3 & 5 \\
\hline
\end{tabular}




\begin{tabular}{|c|c|c|c|c|c|c|c|c|}
\hline 6989 & Tamm-2 & FIN & 60 & 23.5 & $\begin{array}{lll}3 & 3 & 3\end{array}$ & 32 & 43 & 3 \\
\hline 6992 & Ang-0 & BEL & 50.3 & 5.3 & $\begin{array}{lll}5 & 5 & 5\end{array}$ & 5 & 5 & 5 \\
\hline 7067 & Ct-I & ITA & 37.3 & 15 & 213 & 32 & 22 & 2 \\
\hline 7107 & Durh-I & UK & 54.7761 & -1.5733 & 222 & 2 & 13 & 3 \\
\hline 7120 & En-D & GER & 50 & 8.5 & $\begin{array}{lll}3 & 24\end{array}$ & 42 & 43 & 3 \\
\hline 7250 & Me-0 & GER & 51.9183 & 10.1138 & $\begin{array}{lll}3 & 3 & 3\end{array}$ & 33 & $3:$ & 3 \\
\hline 7276 & Ob-0 & GER & 50.2 & 8.5833 & 555 & 55 & 5 & 5 \\
\hline 7287 & Ove-0 & GER & 53.3422 & 8.42255 & 342 & 23 & 3 & 3 \\
\hline 7306 & Pog-0 & CAN & 49.2655 & -123.206 & $\begin{array}{lll}5 & 5 & 5\end{array}$ & 54 & 5 & 5 \\
\hline 7307 & $P n-0$ & FRA & 48.0653 & -2.96591 & $\begin{array}{lll}3 & 2 & 3\end{array}$ & 33 & $4 ?$ & 3 \\
\hline 7347 & Ste- 0 & GER & 52.6058 & II.8558 & 112 & 21 & I & I \\
\hline 7349 & Ta-0 & CZE & 49.5 & 14.5 & 444 & 44 & 3 & 5 \\
\hline 7350 & Tac-0 & USA & 47.2413 & -122.459 & $\begin{array}{lll}32 & 24\end{array}$ & 43 & 3 & 3 \\
\hline 7461 & H55 & CZE & 49 & 15 & $\begin{array}{lll}5 & 5 & 5\end{array}$ & 5 & 5 & 5 \\
\hline 747I & RLD-I & UNK & & & $\begin{array}{lll}5 & 5 & 5\end{array}$ & 5 & 5 & 5 \\
\hline 7947 & PNA3.40 & USA & 42.0945 & -86.3253 & 222 & 2 & 13 & 3 \\
\hline 8214 & Gy-0 & FRA & 49 & 2 & 555 & 55 & 5 & 5 \\
\hline 8227 & THÃ- 03 & SWE & 62.7989 & 17.9103 & $\begin{array}{lll}5 & 5 & 5\end{array}$ & 5 & & 5 \\
\hline 8290 & En-I & GER & 50 & 8.5 & 222 & 21 & 2 & 2 \\
\hline 8311 & $\ln -0$ & AUT & 47.5 & 11.5 & $\begin{array}{lll}3 & 3\end{array}$ & 32 & 4 & 3 \\
\hline 8366 & Sr:5 & SWE & 58.9 & 11.2 & $\begin{array}{lll}5 & 5 & 5\end{array}$ & 5 & 5 & 5 \\
\hline 9058 & Västervik & SWE & 57.75 & 16.6333 & 342 & 23 & 3 & 3 \\
\hline 9067 & Xan-3 & AZE & 38.6536 & 48.7992 & $\begin{array}{lll}3 & 4 & 3\end{array}$ & 33 & 2 & 3 \\
\hline 9102 & Lagl-4 & GEO & 41.8296 & 46.2831 & $5 \quad 55$ & 55 & 5 & 5 \\
\hline 9106 & Lag I-8 & GEO & 41.8296 & 46.2831 & 555 & 5 & 5 & 5 \\
\hline 9121 & Bak-5 & GEO & 41.7942 & 43.4767 & $\begin{array}{lll}3 & 3\end{array}$ & 32 & 4 & 3 \\
\hline 9332 & Bar I & SWE & 62.8698 & $|8.38|$ & $\begin{array}{lll}5 & 5 & 5\end{array}$ & 5 & 5 & 4 \\
\hline 9436 & Puk-I & SWE & 56.1633 & 14.6806 & 445 & 54 & 4 & 4 \\
\hline 9507 & IP-Coa-0 & POR & 38.45 & -7.5 & $\begin{array}{lll}1 & 1 & 1\end{array}$ & 1 & 2 & I \\
\hline 9517 & IP-All-0 & ESP & 42.19 & -7.8 & 332 & 24 & 3 & 3 \\
\hline 9518 & IP-Alm-0 & ESP & 39.88 & -0.36 & $1 \quad 1 \quad 1$ & 11 & 1 & I \\
\hline 9537 & IP-Cum-I & ESP & 38.07 & -6.66 & 434 & 44 & 4 & 4 \\
\hline 9548 & IP-Hoy-0 & ESP & 40.4 & -5 & $\begin{array}{lll}3 & 2 & 4\end{array}$ & 43 & 3 & 4 \\
\hline 9569 & IP-Pds-I & ESP & 42.87 & -6.45 & $\begin{array}{lll}1 & 1 & 1\end{array}$ & 2 & 1 & I \\
\hline 9571 & IP-Pro-0 & ESP & 43.28 & -6.01 & 444 & 44 & 4 & 3 \\
\hline 9590 & IP-Trs-0 & ESP & 43.37 & -5.49 & 555 & 5 & 5 & 5 \\
\hline
\end{tabular}


bioRxiv preprint doi: https://doi.org/101101/2021.01.25.428077; this version posted January 26,2021 . The copyright holder for this preprint (which was not certified by peer review) is the author/funder, who has granted bioRxiv a license to display the preprint in perpetuity. It is made available under aCC-BY 4.0 International license.

\begin{tabular}{lllllllllll}
9610 & Lesno-4 & RUS & 53.04 & 51.96 & 4 & 4 & 4 & 4 & 5 & 3 \\
9611 & Lesno-I & RUS & 53.04 & 51.9 & 3 & 2 & 4 & 3 & 4 & 2 \\
9658 & Nicas-I & ITA & 38.97 & 16.34 & 3 & 3 & 3 & 4 & 2 & 3 \\
9672 & Mitterberg-3-188 & ITA & 46.37 & 11.28 & 3 & 3 & 3 & 3 & 4 & 2 \\
9673 & Mitterberg-3-189 & ITA & 46.37 & 11.28 & 3 & 4 & 2 & 3 & 3 & 3 \\
9708 & Kardz-I & BUL & 41.62 & 25.35 & 5 & 5 & 5 & 5 & 5 & 5 \\
9730 & Bela-I & SVK & 48.47 & 18.94 & 5 & 5 & 5 & 5 & 5 & 5 \\
9735 & Bela-4 & SVK & 48.47 & 18.94 & 5 & 5 & 5 & 5 & 5 & 5 \\
9744 & lasi-I & ROU & 47.16 & 27.59 & 4 & 4 & 4 & 4 & 5 & 3 \\
9774 & Alt-I & GER & 48.59 & 9.22 & 1 & 1 & 1 & 1 & 1 & 2 \\
9783 & Tu-PK-7 & GER & 48.52 & 9.05 & 3 & 3 & 3 & 2 & 4 & 3 \\
9853 & Lac-0 & ESP & 43.33 & -5.91 & 3 & 4 & 2 & 3 & 3 & 3 \\
9897 & Smt-I & ESP & 40.95 & -5.63 & 1 & 1 & 1 & 1 & 2 & 1 \\
9905 & Ven-0 & ESP & 40.76 & -4.01 & 1 & 1 & 1 & 1 & 2 & 1 \\
9941 & Fei-0 & POR & 40.92 & -8.54 & 2 & 2 & 2 & 2 & 3 & 1 \\
\hline 10002 & TueWal-2 & GER & 48.53 & 9.04 & 3 & 3 & 3 & 3 & 4 & 3 \\
\hline 9 & & & & & & & & & &
\end{tabular}


Table 2. Sequence differences between Ty-0 and Est-I at ACD6. Position relative to Col-0 reference sequence.

\begin{tabular}{|c|c|c|c|c|c|}
\hline SNP & Position & Est- I & Ty-0 & Annotation & SNP effect \\
\hline I & -3393 & G & A & Upstream of ATG & Unknown \\
\hline 2 & -3375 & $C$ & TCC & Upstream of ATG & Unknown \\
\hline 3 & -3190 & G & $\mathrm{T}$ & Upstream of ATG & Unknown \\
\hline 4 & -3162 & $A$ & deletion & Upstream of ATG & Unknown \\
\hline 5 & -3145 & $\mathrm{C}$ & A & Upstream of ATG & Unknown \\
\hline 6 & -3074 & C & $\mathrm{T}$ & Upstream of ATG & Unknown \\
\hline 7 & -2926 & $\mathrm{~T}$ & C & Upstream of ATG & Unknown \\
\hline 8 & -2825 & $A$ & C & Upstream of ATG & Unknown \\
\hline 9 & -2664 & C & A & Upstream of ATG & Unknown \\
\hline 10 & -2552 & $A$ & $\mathrm{~T}$ & Upstream of ATG & Unknown \\
\hline II & -2392 & G & $\mathrm{T}$ & Upstream of ATG & Unknown \\
\hline 12 & -2454 & A & $\mathrm{T}$ & Upstream of ATG & Unknown \\
\hline 13 & -2224 & A & G & Upstream of ATG & Unknown \\
\hline 14 & -2159 & G & A & Upstream of ATG & Unknown \\
\hline 15 & -1978 & $\mathrm{C}$ & deletion & Upstream of ATG & Unknown \\
\hline 16 & -1977 & A & deletion & Upstream of ATG & Unknown \\
\hline 17 & -1817 & $A$ & C & Upstream of ATG & Unknown \\
\hline 18 & -1796 & $A$ & C & Upstream of ATG & Unknown \\
\hline 19 & -1759 & G & $A$ & Upstream of ATG & Unknown \\
\hline 20 & -1698 & G & deletion & Upstream of ATG & Unknown \\
\hline 21 & -1639 & $\mathrm{~T}$ & C & Upstream of ATG & Unknown \\
\hline 22 & -1612 & $\mathrm{~T}$ & deletion & Upstream of ATG & Unknown \\
\hline 23 & $-|6| 1$ & $\mathrm{~T}$ & deletion & Upstream of ATG & Unknown \\
\hline 24 & -1610 & A & deletion & Upstream of ATG & Unknown \\
\hline 25 & -1569 & C & A & Upstream of ATG & Unknown \\
\hline 26 & -1554 & $\mathrm{~T}$ & C & Upstream of ATG & Unknown \\
\hline 27 & -1543 & A & G & Upstream of ATG & Unknown \\
\hline 28 & -1496 & A & $\mathrm{T}$ & Upstream of ATG & Unknown \\
\hline 29 & -1357 & G & C & Upstream of ATG & Unknown \\
\hline 30 & -1299 & A & G & Upstream of ATG & Unknown \\
\hline 31 & -1233 & G & A & Upstream of ATG & Unknown \\
\hline 32 & -1187 & T & C & Upstream of ATG & Unknown \\
\hline 33 & -1185 & G & C & Upstream of ATG & Unknown \\
\hline 34 & -1166 & $\mathrm{~T}$ & G & Upstream of ATG & Unknown \\
\hline 35 & -1088 & T & A & Upstream of ATG & Unknown \\
\hline 36 & -1086 & A & AT & Upstream of ATG & Unknown \\
\hline 37 & -921 & $\mathrm{~T}$ & G & Upstream of ATG & Unknown \\
\hline 38 & -755 & C & G & Upstream of ATG & Unknown \\
\hline 39 & -744 & $\mathrm{~T}$ & deletion & Upstream of ATG & Unknown \\
\hline 40 & -698 & G & deletion & Upstream of ATG & Unknown \\
\hline 41 & -622 & $A$ & C & Upstream of ATG & Unknown \\
\hline 42 & -572 & $\mathrm{~T}$ & C & Upstream of ATG & Unknown \\
\hline 43 & -449 & C & A & Upstream of ATG & Unknown \\
\hline 44 & 990 & A & deletion & Intron & Unknown \\
\hline 45 & 1213 & A & $\mathrm{T}$ & Intron & Unknown \\
\hline
\end{tabular}


bioRxiv preprint doi: https://doi org/101101/2021.0125,428077; this version posted January 26,2021 . The copyright holder for this preprint (which was not certified by peer review) is the author/funder, who has granted bioRxiv a license to display the preprint in perpetuity. It is made available under aCC-BY 4.0 International license.

Table 3. Analysis of EMS induced mutations in 72 somhal lines with suppressed MHAL overexpression defects. Shown are candidate mutations, which are all G>A (C>T) changes, as typical for EMS, from 52 lines in three genes, XRN4, RSTI and ACD6, with multiple hits. Mutations in RSTI and XRN4 are known for transgene silencing (Gazzani et al., 2004; Lange et al., 2019; Li et al., 20 I9). In the remaining 20 lines, mutations were found, but without any overlapping genes. NA, not applicable. Ref., reference base. Alt., alternative base.

\begin{tabular}{|c|c|c|c|c|c|c|c|}
\hline Suppressor ID & Gene ID & Gene & Amino acid & Chr. & Pos. (bp) & Ref. & Alt. \\
\hline 269 & ATIG54490 & $X R N 4$ & Gln II5STOP & I & $20,35 I, 48 I$ & C & $\mathrm{T}$ \\
\hline 57 & ATIG54490 & XRN4 & Trp643STOP & I & $20,355,270$ & G & A \\
\hline 225 & ATIG54490 & XRN4 & Gln666STOP & 1 & $20,355,433$ & C & $\mathrm{T}$ \\
\hline 242 & ATIG54490 & XRN4 & Gln666STOP & 1 & $20,355,433$ & C & $\mathrm{T}$ \\
\hline 243 & AT3G27670 & RSTI & TrpI I9STOP & 3 & $10,245,694$ & G & A \\
\hline 220 & AT3G27670 & RSTI & Trp336STOP & 3 & $10,246,522$ & G & A \\
\hline 42 & AT3G27670 & RSTI & Trp422STOP & 3 & $10,246,874$ & G & A \\
\hline 110 & AT3G27670 & RSTI & Trp422STOP & 3 & $10,246,875$ & G & A \\
\hline 310 & AT3G27670 & RSTI & Trp59ISTOP & 3 & $10,247,715$ & G & A \\
\hline 320 & AT3G27670 & RSTI & Gln687STOP & 3 & $10,248,260$ & C & $\mathrm{T}$ \\
\hline 8 & AT3G27670 & RSTI & Trp705STOP & 3 & $10,248,453$ & G & A \\
\hline 10 & AT3G27670 & RSTI & TrpI I58STOP & 3 & $|0,250,75|$ & G & A \\
\hline 31 & AT3G27670 & RSTI & TrpI360STOP & 3 & $10,25 \mid, 455$ & G & A \\
\hline 379 & AT3G27670 & RSTI & Gln I800STOP & 3 & $10,253,030$ & C & T \\
\hline 91 & AT3G27670 & RSTI & Gln I803STOP & 3 & $10,253,039$ & C & $\mathrm{T}$ \\
\hline 46 & AT4GI4400 & $A C D 6$ & TrpIIISTOP & 4 & $8,296,469$ & G & A \\
\hline 412 & AT4GI4400 & $A C D 6$ & Ala I86Val & 4 & $8,296,693$ & $\mathrm{C}$ & $\mathrm{T}$ \\
\hline 454 & AT4GI4400 & $A C D 6$ & Ala I86Val & 4 & $8,296,693$ & $\mathrm{C}$ & $\mathrm{T}$ \\
\hline 363 & AT4GI4400 & $A C D 6$ & Leu265Phe & 4 & $8,296,929$ & C & $\mathrm{T}$ \\
\hline 528 & AT4GI4400 & $A C D 6$ & Leu278Phe & 4 & $8,297,096$ & C & $\mathrm{T}$ \\
\hline 194 & AT4GI4400 & ACD6 & Leu300Phe & 4 & $8,297,162$ & C & $\mathrm{T}$ \\
\hline 78 & AT4GI4400 & $A C D 6$ & Asp329Asn & 4 & $8,297,249$ & G & A \\
\hline 191 & AT4GI4400 & $A C D 6$ & Ala337Val & 4 & $8,297,274$ & C & $\mathrm{T}$ \\
\hline 253 & AT4GI4400 & $A C D 6$ & Ala338Thr & 4 & $8,297,276$ & G & A \\
\hline 104 & AT4GI4400 & ACD6 & Leu368Phe & 4 & $8,297,366$ & $\mathrm{C}$ & $\mathrm{T}$ \\
\hline 293 & AT4GI4400 & $A C D 6$ & Leu368Phe & 4 & $8,297,366$ & C & $\mathrm{T}$ \\
\hline 513 & AT4GI4400 & $A C D 6$ & Ala37IThr & 4 & $8,297,375$ & G & A \\
\hline 113 & AT4GI4400 & $A C D 6$ & Thr402lle & 4 & $8,297,469$ & C & $\mathrm{T}$ \\
\hline 399 & AT4GI4400 & $A C D 6$ & His405Tyr & 4 & $8,297,477$ & C & $\mathrm{T}$ \\
\hline 531 & AT4GI4400 & $A C D 6$ & Ala437Thr & 4 & $8,297,573$ & G & A \\
\hline
\end{tabular}


bioRxiv preprint doi: https://doi.org/10.1101/2021.01.25.428077; this version posted January 26,2021 . The copyright holder for this preprint (which was not certified by peer review) is the author/funder, who has granted bioRxiv a license to display the preprint in perpetuity. It is made available under aCC-BY 4.0 International license.

Regulation of ACD6 ion channel-like protein by small peptides

\begin{tabular}{|c|c|c|c|c|c|c|c|}
\hline I & AT4GI4400 & ACD6 & Ala458Thr & 4 & $8,297,719$ & G & $A$ \\
\hline 529 & AT4GI4400 & ACD6 & Ala458Thr & 4 & $8,297,719$ & G & A \\
\hline 146 & AT4GI4400 & ACD6 & Thr476Ile & 4 & $8,297,774$ & C & $\mathrm{T}$ \\
\hline 539 & AT4G I 4400 & ACD6 & Ala507Val & 4 & $8,297,867$ & C & $\mathrm{T}$ \\
\hline 406 & AT4GI4400 & ACD6 & Ala546Thr & 4 & $8,297,983$ & G & A \\
\hline 95 & AT4GI4400 & $A C D 6$ & Leu557Phe & 4 & $8,298,016$ & C & $\mathrm{T}$ \\
\hline 70 & AT4G I 4400 & $A C D 6$ & Ala575Thr & 4 & $8,298,070$ & G & A \\
\hline 122 & AT4GI4400 & ACD6 & Gly593Asp & 4 & $8,298,125$ & G & A \\
\hline 337 & AT4GI4400 & ACD6 & Leu623Phe & 4 & $8,298,2 \mid 4$ & C & $\mathrm{T}$ \\
\hline 449 & AT4GI4400 & $A C D 6$ & Gly624Asp & 4 & $8,298,218$ & G & A \\
\hline 540 & AT4GI4400 & ACD6 & Gly624Asp & 4 & $8,298,218$ & G & A \\
\hline 274 & AT4GI4400 & $A C D 6$ & Pro635Leu & 4 & $8,298,25 \mid$ & C & T \\
\hline 34 & AT4GI4400 & ACD6 & Pro635Leu & 4 & $8,298,251$ & C & T \\
\hline 413 & AT4GI4400 & ACD6 & Pro635Leu & 4 & $8,298,251$ & $C$ & T \\
\hline 472 & AT4GI4400 & ACD6 & Pro635Leu & 4 & $8,298,251$ & C & T \\
\hline 308 & AT4GI4400 & ACD6 & Pro636Ser & 4 & $8,298,253$ & C & $\mathrm{T}$ \\
\hline 200 & AT4GI4400 & ACD6 & Pro636Leu & 4 & $8,298,254$ & C & $\mathrm{T}$ \\
\hline 421 & AT4GI4400 & ACD6 & Ser638Phe & 4 & $8,298,260$ & C & $\mathrm{T}$ \\
\hline 435 & AT4GI4400 & $A C D 6$ & Ser638Phe & 4 & $8,298,260$ & C & $\mathrm{T}$ \\
\hline 475 & AT4GI4400 & ACD6 & Ser638Phe & 4 & $8,298,260$ & $C$ & $\mathrm{~T}$ \\
\hline 489 & AT4GI4400 & ACD6 & Ser638Phe & 4 & $8,298,260$ & C & $\mathrm{T}$ \\
\hline 391 & AT4GI4400 & $A C D 6$ & Gly664Asp & 4 & $8,298,338$ & G & A \\
\hline 4 & NA & NA & NA & NA & NA & NA & NA \\
\hline 13 & NA & NA & NA & NA & NA & NA & NA \\
\hline 14 & NA & NA & NA & NA & NA & NA & NA \\
\hline 21 & NA & NA & NA & NA & NA & NA & NA \\
\hline 32 & NA & NA & NA & NA & NA & NA & NA \\
\hline 67 & NA & NA & NA & NA & NA & NA & NA \\
\hline 82 & NA & NA & NA & NA & NA & NA & NA \\
\hline 86 & NA & NA & NA & NA & NA & NA & NA \\
\hline 89 & NA & NA & NA & NA & NA & NA & NA \\
\hline 183 & NA & NA & NA & NA & NA & NA & NA \\
\hline 186 & NA & NA & NA & NA & NA & NA & NA \\
\hline 197 & NA & NA & NA & NA & NA & NA & NA \\
\hline 245 & NA & NA & NA & NA & NA & NA & NA \\
\hline 272 & NA & NA & NA & NA & NA & NA & NA \\
\hline 333 & NA & NA & NA & NA & NA & NA & NA \\
\hline 344 & NA & NA & NA & NA & NA & NA & NA \\
\hline 364 & NA & NA & NA & NA & NA & NA & NA \\
\hline
\end{tabular}


bioRxiv preprint doi: https://doi.org/10.1101/2021.01.25.428077; this version posted January 26, 2021. The copyright holder for this preprint (which was not certified by peer review) is the author/funder, who has granted bioRxiv a license to display the preprint in perpetuity. It is made available under aCC-BY 4.0 International license.

Zhu et al.

Regulation of ACD6 ion channel-like protein by small peptides

\begin{tabular}{|c|c|c|c|c|c|c|c|}
\hline 384 & NA & NA & NA & NA & NA & NA & NA \\
\hline 425 & NA & NA & NA & NA & NA & NA & NA \\
\hline 438 & NA & NA & NA & NA & NA & NA & NA \\
\hline
\end{tabular}


bioRxiv preprint doi: https://doi.org/101101/2021.0125.428077; this version posted January $26,2021$. The copyright holder for this preprint (which was not certified by peer review) is the author/funder, who has granted bioRxiv a license to display the preprint in perpetuity. It is made available under aCC-BY 4.0 International license.

Table 4. Gain-of-function mutations in TRP channel genes.

\begin{tabular}{|c|c|c|c|c|}
\hline Channel & Organism & Location & Sequence & Comments/References \\
\hline TRP (TRPCI) & Drosophila & S5 & $\mathrm{F}>\mathrm{I}$ & (Hong et al., 2002) \\
\hline TRPAI & Human & S4 & $N>S$ & (Kremeyer et al., 20l0) \\
\hline TRPM3 & Human & $\begin{array}{l}\text { L4-5 } \\
\text { S5 }\end{array}$ & $\begin{array}{l}V>M \\
P>Q\end{array}$ & (Van Hoeymissen et al., 2020) \\
\hline TRPM4 & Human & $\begin{array}{l}\text { ANK } \\
\text { ANK-TM linker } \\
\text { L3-S4 }\end{array}$ & $\begin{array}{l}R>T \\
A>T \\
G>D\end{array}$ & (Liu et al., 2010) \\
\hline TRPM4 & Human & S6 & $\begin{array}{l}\mathrm{I}>\mathrm{M} \\
\mathrm{I}>\mathrm{T} \\
\mathrm{A}>\mathrm{T}\end{array}$ & (H. Wang et al., 2019) \\
\hline TRPC4 & Human & C-terminus & $1>V$ & $\begin{array}{l}\text { Proposed to affect regulation by Fyn kinase } \\
\text { (Jung et al., 20II) }\end{array}$ \\
\hline TRPC6 & Human & $\begin{array}{l}\text { ANK } \\
\text { C-terminus }\end{array}$ & $\begin{array}{l}P>Q \\
R>C \\
E>K\end{array}$ & (Reiser et al., 2005; Winn et al., 2005) \\
\hline $\begin{array}{l}\text { TRPC6, } \\
\text { TRPMLI, } \\
\text { TRPML2, } \\
\text { TRPML3, } \\
\text { TRPV2, TRPV5, } \\
\text { TRPV6 }\end{array}$ & $\begin{array}{l}\text { Human, } \\
\text { mouse }\end{array}$ & $\begin{array}{l}\text { S5 } \\
\text { L4-5 }\end{array}$ & $\begin{array}{l}A>P \\
C>P \\
V>P \\
R Y>P\end{array}$ & $\begin{array}{l}\text { (Dong et al., 2009; Grimm et al., 2007; Kim } \\
\text { et al., 2007; Nagata et al., 2008; Xu et al., } \\
\text { 2007) }\end{array}$ \\
\hline TRPP2 & Human & S5 & $\mathrm{F}>\mathrm{P}$ & (Arif Pavel et al., 20I6) \\
\hline TRPVI & Rat & $\begin{array}{l}\text { ANK } \\
\text { S5 } \\
\text { L5-6 }\end{array}$ & $\begin{array}{l}K>E \\
M>T \\
F>L\end{array}$ & (Myers et al., 2008a) \\
\hline TRPVI & Rat & $\begin{array}{l}\text { S4 } \\
\text { L4-5 }\end{array}$ & $\begin{array}{l}R>K \\
G>S\end{array}$ & (Boukalova et al., 2010) \\
\hline TRPVI & Human & $\begin{array}{l}\text { L4-5 } \\
\text { C-terminus }\end{array}$ & $\begin{array}{l}\mathrm{G}>\mathrm{S} \\
\mathrm{G}>\mathrm{C} \\
\mathrm{T}>\mathrm{G}\end{array}$ & (Lin et al., 20I2) \\
\hline TRPV3 & Human & $\begin{array}{l}\text { ANK-TM linker } \\
\text { L4-5 } \\
\text { C-terminus }\end{array}$ & $\begin{array}{l}G>S \\
G>C \\
W>G \\
G>A \\
W>C \\
L>F\end{array}$ & (Wang and Wang, 20I7) \\
\hline TRPV4, TRPV6 & Human & C-terminus & $\begin{array}{l}S>D \\
T>D\end{array}$ & $\begin{array}{l}\text { Mimics phosphorylation by calmodulin } \\
\text { (Arbabian et al., 2020) }\end{array}$ \\
\hline TRPV4 & Human & C-terminus & Frame shift & $\begin{array}{l}\text { Proposed to alter regulation by calmodulin } \\
\text { (Mah et al., 2016) }\end{array}$ \\
\hline TRPV4 & Human & ANK & $\begin{array}{l}\mathrm{R}>\mathrm{C} \\
\mathrm{R}>\mathrm{H}\end{array}$ & (Landouré et al., 20I0) \\
\hline TRPYI & Yeast & S5 & $F>L$ & (Su et al., 2007) \\
\hline
\end{tabular}


Table 5. Oligonucleotide primers for SSLP markers.

\begin{tabular}{|c|c|c|c|c|}
\hline \multirow{2}{*}{$\begin{array}{l}\text { SSLP } \\
\text { marker }\end{array}$} & \multirow{2}{*}{ Primer sequences } & \multirow{2}{*}{$\begin{array}{l}\text { Position } \\
\text { (chr I bp) }\end{array}$} & \multicolumn{2}{|c|}{ PCR product } \\
\hline & & & Ty-0 & Est- I \\
\hline NGAI 28 & GGTCTGTTGATGTCGTAAGTCG & & \multirow{2}{*}{ Small } & \multirow{2}{*}{ Large } \\
\hline NGAI 28 & ATCTTGAAACCTTTAGGGAGGG & $20,633,250$ & & \\
\hline TI3D8 & GTTAGCTCTTCCGAGATCTG & & \multirow{2}{*}{ Large } & \multirow{2}{*}{ Small } \\
\hline TI3D8 & CGGCGAGAATGATGGAAGGC & $22,172,802$ & & \\
\hline $\mathrm{F} 23 \mathrm{C} 2 \mathrm{I}$ & ATGGATTAGTTGTGCTACAG & & \multirow{2}{*}{ Large } & \multirow{2}{*}{ Small } \\
\hline$F 23 C 2 I$ & TGTTCATGGATATAAATAGA & $22,408,632$ & & \\
\hline T7PI & ATGTACCATCTTACCATTAT & & \multirow{2}{*}{ Large } & \multirow{2}{*}{ Small } \\
\hline T7PI & GACCATTGGATTGCTAAC & $22,422,576$ & & \\
\hline FIIPI7 & CGCAATCGATTTTTATTTAAAATCC & & \multirow{2}{*}{ Small } & \multirow{2}{*}{ Large } \\
\hline FIIPI7 & TTTCAGTTTGATGATTTATTCGC & $22,60 I, 704$ & & \\
\hline TIF9 & TTTCAGTTTGATGATTTATTCGC & & \multirow{2}{*}{ Small } & \multirow{2}{*}{ Large } \\
\hline TIF9 & CGCAATCGATTTTATTTTAAATCC & $22,689,057$ & & \\
\hline SNPI & $\begin{array}{l}\text { GATGTAAATTGGCAGCATATTGATCC } \\
\mathrm{T}\end{array}$ & & \multirow[t]{2}{*}{ C } & \multirow{2}{*}{ G } \\
\hline SNPI & TATCATTTAGAAGTTCTTTATCCG & $22,832,222$ & & \\
\hline MHAI & AAAACGACGGCGTAATGAAC & & \multirow{2}{*}{ Large } & \multirow{2}{*}{ Small } \\
\hline MHAI & ATAAGAATCACAATCACTCTTTTTTGAG & $22,939,031$ & & \\
\hline SNP2 & TGATCTGCACTCTGCGAAAACA & & \multirow{2}{*}{$A$} & \multirow{2}{*}{ G } \\
\hline SNP2 & CATCCTCGCTCTCTTCTGTATCGA & $23,029,085$ & & \\
\hline F24D7 & TATAACCAGTTTTTCAAATCAAC & & \multirow{2}{*}{ Small } & \multirow{2}{*}{ Large } \\
\hline F24D7 & GCTTCTTGTGGTCGTTTT & $23,629,412$ & & \\
\hline
\end{tabular}


bioRxiv preprint doi: https://doi.org/10.1101/2021.01.25.428077; this version posted January 26, 2021. The copyright holder for this preprint (which was not certified by peer review) is the author/funder, who has granted bioRxiv a license to display the preprint in perpetuity. It is made available under aCC-BY 4.0 International license.

Zhu et al.

Regulation of ACD6 ion channel-like protein by small peptides

Table 6. Guide RNAs for CRISPR/Cas9 genome editing.

\begin{tabular}{llll}
\hline sgRNA & sgRNA sequence & Gene & Reference Construct \\
\hline$I$ & TAATAACATGTAGGCAACT & ATIG62045 (MHAI) & PWZI56 \\
2 & GGCATCTCCCCGATCCCTC & ATIG62045 (MHAI) & PWZI56 \\
3 & GGAATTGGGGTGATGGCTG & ATIGII740(MHAL) & PWZI57 \\
4 & GATGAAGAATCTTGTGCAG & ATIGII740(MHAL) & pWZI57 \\
5 & TGGCCAGAGTTCTTACCGC & ATIG62045 (MHAI) & PWZ92 \\
\hline
\end{tabular}


Table 7. Other oligonucleotide primers.

\begin{tabular}{|c|c|c|}
\hline Primer & Sequence & Purpose \\
\hline G-42937 & TAATAACATGTAGGCAACt & $\begin{array}{l}\text { Genotyping of MHAI CRISPR } \\
\text { mutants }\end{array}$ \\
\hline G-4I4I4 & GGCATCTCCCCGATCCCTC & $\begin{array}{l}\text { Genotyping of MHAI CRISPR } \\
\text { mutants }\end{array}$ \\
\hline G-42803 & TCATCCAAAATCGGTCATTCTCTCTTTAGT & $\begin{array}{l}\text { Genotyping of MHAL CRISPR } \\
\text { mutants }\end{array}$ \\
\hline G-428I9 & TGGTCAACCAAGAGAATGTGTC & $\begin{array}{l}\text { Genotyping of MHAL CRISPR } \\
\text { mutants }\end{array}$ \\
\hline G- 17802 & TATCCCTAGCTCTTAAGCCGC & Genotyping of acd6-2 \\
\hline G-17803 & TGGGGTCATCTGGAACTAGTG & Genotyping of $a c d 6-2$ \\
\hline G-44507 & ATGGCAAGTGAAGCACCGAGTTG & qRT-PCR MHAI \\
\hline G-44508 & СTTATCTTTCAAGAATCAGAGTC & qRT-PCR MHAI \\
\hline G-446I0 & ATGGCGAGTGAAGCACCTAGTTG & qRT-PCR MAL \\
\hline G-44644 & CTATGAAGAAGTAGAATCCTTC & qRT-PCR MAL \\
\hline G-16287 & ATCACTGCAATTGCCCATGT & qRT-PCR ACD6 \\
\hline G-16288 & ACACGCCACACAACCAAAA & qRT-PCR ACD6 \\
\hline G-13182 & CGTTCACATAATTCCCACGA & qRT-PCR PRI \\
\hline G-13183 & AAGAGGCAACTGCAGACTCA & qRT-PCR PRI \\
\hline G-27290 & GCCATCCAAGCTGTTCTCTC & qRT-PCR ACTIN2 \\
\hline G-2729। & GCTCGTAGTCAACAGCAACAA & qRT-PCR ACTIN2 \\
\hline
\end{tabular}

\begin{tabular}{lll}
\hline G-16352 & GAGTTTGTAGCCTATTCAAAGGCATT & Cloning, see Table 8 \\
G-40339 & CATCGACGTGGCTGAGACTA & Cloning, see Table 8 \\
G-41082 & TTATTCGGAACACGCCACACAAC & Cloning, see Table 8 \\
G-41326 & GTGTGCCTTCCAATGCTTTT & Cloning, see Table 8 \\
G-41413 & GTGTGGTAAACAATTTGTGAG & Cloning, see Table 8 \\
G-41414 & GCTAAATCAAAATCGTCTTTC & Cloning, see Table 8 \\
G-4188I & GAAAGACGATTTTGATTAGC & Cloning, see Table 8 \\
G-41882 & ATTGCGATATCTTTTCGCAAA & Cloning, see Table 8 \\
G-42331 & GATCAGGTACCATGGCAAGTGAAGCACCGA & Cloning, see Table 8 \\
G-42332 & TGACTGAATTCTCAAGAATCAGAGTCTTTC & Cloning, see Table 8 \\
G-4259I & ACGGGGGACGAGCTCGGTACATGGCAAGTGAAGCACCGA & Cloning, see Table 8 \\
G-42592 & GACGCGTACGAGATCTGGTCAGAATCAGAGTCTTTCTTCTTC & Cloning, see Table 8 \\
G-42595 & ACGCGTCCCGGGGCGGTACCATGGACAGTTCTGGAGCAGAT & Cloning, see Table 8 \\
G-42596 & ACGAACGAAAGCTCTGCAGGTTATTCGGAACACGCCACAC & Cloning, see Table 8 \\
G-42684 & CGGGTACCATGGCAAGTGAAGCACCGAG & Cloning, see Table 8 \\
G-42685 & AGGTTCGAAAGAATCAGAGTCTTTCTTCT & Cloning, see Table 8 \\
G-42686 & CGGGTACCATGGACAGTTCTGGAGCAGATC & Cloning, see Table 8 \\
G-42687 & CGATCGATTTCGGAACACGCCACACAAC & Cloning, see Table 8 \\
G-42954 & ATGGACAGTTCTGGAGCAGAT & Cloning, see Table 8 \\
G-43182 & TACAAACTTTGGATTCACATACA & Cloning, see Table 8 \\
G-43183 & AGGTTCGAAGCTTTTGTTTCGTAATTTCAG & Cloning, see Table 8 \\
G-43214 & ACGGGGGCGAGCTCGGTACATGGCGAGTGAAGCACCTAG & Cloning, see Table 8
\end{tabular}


bioRxiv preprint doi: https://doi.org/10.1101/2021.01.25.428077; this version posted January $26,2021$. The copyright holder for this preprint (which was not certified by peer review) is the author/funder, who has granted bioRxiv a license to display the preprint in perpetuity. It is made available under aCC-BY 4.0 International license.

Zhu et al. Regulation of ACD6 ion channel-like protein by small peptides

\begin{tabular}{|c|c|c|}
\hline G-432I4 & ACGGGGGACGAGCTCGGTACATGGCGAGTGAAGCACCTAG & Cloning, see Table 8 \\
\hline G-4324I & CGGGATCCATGGACAGTTCTGGAGCAGATC & Cloning, see Table 8 \\
\hline G-43242 & AGGGTCGACTCAGCTTTTTGTTTCGTAATTTCAG & Cloning, see Table 8 \\
\hline G-43374 & AGGTTCGAATGAAGAAGTAGAATCCTTCTTC & Cloning, see Table 8 \\
\hline G-43478 & $\begin{array}{l}\text { GAGAACACGGGGGACGAGCTCGGTACCTCTACATTCTCCACAT } \\
\text { TTCCA }\end{array}$ & Cloning, see Table 8 \\
\hline G-43480 & $\begin{array}{l}\text { AGTCAGGAACATCGTATGGGTATTCGAATGAAGAAGTAGAATC } \\
\text { CTTCTTC }\end{array}$ & Cloning, see Table 8 \\
\hline G-43790 & CGGGTACCATGGCGAGTGAAGCAC & Cloning, see Table 8 \\
\hline G-4379I & CGGGATCCTGAAGAAGTAGAATCCTTC & Cloning, see Table 8 \\
\hline G-44I 40 & GAGATTTTTGATGGAATGAGTAAT & Cloning, see Table 8 \\
\hline G-44I4I & ATTACTCATTCCAtCAAAAАTCTC & Cloning, see Table 8 \\
\hline G-44I42 & CTACATGTGGTTACTCATGGC & Cloning, see Table 8 \\
\hline G-44I43 & GCCATGAGTAaCCACATGTAG & Cloning, see Table 8 \\
\hline G-44I 44 & ATGGAAATACTGtTCTGTACTACGC & Cloning, see Table 8 \\
\hline G-44I45 & GCGTAGTACAGAaCAGTATTTCCAT & Cloning, see Table 8 \\
\hline G-44I46 & TTGCACATGTTGtTTTGAAGGCCAA & Cloning, see Table 8 \\
\hline G-44I47 & TTGGCCTTCAAAaCAACATGTGCAA & Cloning, see Table 8 \\
\hline G-44I 48 & GGTAGGACTTGTtTTTCATACGGAG & Cloning, see Table 8 \\
\hline G-44I49 & CTCCGTATGAAAaACAAGTCCTACC & Cloning, see Table 8 \\
\hline G-44I50 & GTTTTTCATACGaAGCATCCATTGG & Cloning, see Table 8 \\
\hline G-44I5I & CCAATGGATGCTtCGTATGAAAAAC & Cloning, see Table 8 \\
\hline G-44I52 & AAGCATCCATTGaGTATTATAAAGG & Cloning, see Table 8 \\
\hline G-44I53 & СCTTTATAATACtCAATGGATGCTT & Cloning, see Table 8 \\
\hline G-44I54 & AGTATTATAAAGaACTATGCAACAT & Cloning, see Table 8 \\
\hline G-44I55 & ATGTTGCATAGTtCTTTATAATACT & Cloning, see Table 8 \\
\hline G-44I56 & ACGAAATTATTAAAaAGTTTATAAAACGT & Cloning, see Table 8 \\
\hline G-44I57 & ACGTTTTATAAACTtTTTAAATAATTTCGT & Cloning, see Table 8 \\
\hline G-44I 58 & AGGTTCGAACCCGGTGACGTCTTTT & Cloning, see Table 8 \\
\hline G-44I59 & CGGGTACCATGGCTGCGGAGGAGA & Cloning, see Table 8 \\
\hline
\end{tabular}

G-42275 TGGCCAGAGTTCTTACCGCGTTTTAGAGCTATGCTGAAA

G-42289 GCGGTAAGAACTCTGGCCACAATCACTACTTCGACTCTA

G-42795 TAATAACATGTAGGCAACtGTTTTAGAGCTATGCTGAAA

G-42796 aGTTGCCTACATGTTATTACAATCACTACTTCGACTCTA

G-42797 GATGAAGAATCTTGTGCAGGTTTTAGAGCTATGCTGAAA

G-42798 CTGCACAAGATTCTTCATCCAATCACTACTTCGACTCTA
Generation of E-gRNA-MHAI backbone, related to PWZ092 in Table 8

Generation of E-gRNA-MHAI backbone, related to pWZ092 in Table 8

Generation of D-gRNA-MHAI backbone, related to PWZI56 in Table 8

Generation of D-gRNA-MHAI backbone, related to pWZI56 in Table 8

Generation of D-gRNA-MHAI backbone, related to PWZI56 in Table 8

Generation of D-gRNA-MAL backbone, related to pWZI57 in Table 8 
bioRxiv preprint doi: https://doi.org/10.1101/2021.01.25.428077; this version posted January 26, 2021. The copyright holder for this preprint (which was not certified by peer review) is the author/funder, who has granted bioRxiv a license to display the preprint in perpetuity. It is made available under aCC-BY 4.0 International license.

G-42560 GGAATTGGGGTGATGGCTGGTTTTAGAGCTATGCTGAAA

G-4256I CAGCCATCACCCCAATTCCCAATCACTACTTCGACTCTA
Generation of E-gRNA-MAL backbone, related to pWZI57 in Table 8

Generation of E-gRNA-MAL backbone, related to pWZI57 in Table 8 
Table 8. Key to constructs.

\begin{tabular}{|c|c|c|c|c|c|c|}
\hline \multirow[t]{2}{*}{ Name } & \multirow[t]{2}{*}{ Backbone } & \multirow[t]{2}{*}{ Insert } & \multicolumn{2}{|c|}{$\begin{array}{l}\text { Restriction } \\
\text { sites }\end{array}$} & \multirow{2}{*}{$\begin{array}{l}\text { Protein } \\
\text { tag }\end{array}$} & \multirow[t]{2}{*}{ Gene } \\
\hline & & & 5 & 3' & & \\
\hline pWZ092 & pGreen-IIS & E-ssgRNAs:MHAI & \multicolumn{2}{|c|}{ GreenGate } & - & ATIG62045 \\
\hline pWZI56 & pGreen-IIS & D/E-ssgRNAs:MHAI & \multicolumn{2}{|c|}{ GreenGate } & - & ATIG62045 \\
\hline pWZI57 & pGreen-IIS & D/E-ssgRNAs:MHAL & \multicolumn{2}{|c|}{ GreenGate } & - & ATIGII736 \\
\hline pWZOI9 & pFK210 & MHAIcDNA (Est-I) & \multicolumn{2}{|c|}{ Gateway } & - & ATIG62045 \\
\hline pWZ020 & pFK210 & MHAI cDNA (Ty-0) & \multicolumn{2}{|c|}{ Gateway } & - & ATIG62045 \\
\hline pWZ052 & pFK210 & MHAI cDNA (Est-I) & \multicolumn{2}{|c|}{ Gateway } & mGFP & ATIG62045 \\
\hline pWZ053 & pFK210 & MHAI cDNA (Ty-0) & \multicolumn{2}{|c|}{ Gateway } & mGFP & ATIG62045 \\
\hline pWZ054 & pFK206 & gMHAI (Est-I) & \multicolumn{2}{|c|}{ Gateway } & - & ATIG62045 \\
\hline pWZ055 & pFK206 & gMHAI (Ty-0) & \multicolumn{2}{|c|}{ Gateway } & - & ATIG62045 \\
\hline pWZII8 & pFK206 & gACD6 (Ty-0) & \multicolumn{2}{|c|}{ Gateway } & - & AT4G I 4400 \\
\hline pWZI66 & pFK206 & gACD6 (Est-I) & \multicolumn{2}{|c|}{ Gateway } & $3 \times F L A G$ & AT4G I 4400 \\
\hline pWZI86 & pFAST-G02 & MHAL CDS & \multicolumn{2}{|c|}{ Gibson assembly } & - & ATIGII736 \\
\hline pWZ228 & pFAST-G02 & MHAL CDS & \multicolumn{2}{|c|}{ Gibson assembly } & mGFP & ATIGII736 \\
\hline pLLI34 & pUC-19 & ACD6 (Col-0) & Kpnl & Clal & $3 \times F L A G$ & AT4G I 4400 \\
\hline pLLI45 & PUC-19 & MHAI (Est-I) & Kpnl & Bspl|9| & HA-GFP & ATIG62045 \\
\hline pLLI75 & pUC-19 & ACD6-ANK (Col-0) & Kpnl & Bspl|9| & FLAG & AT4G I 4400 \\
\hline pLL206 & pGEX-6p-I & ACD6-ANK (Col-0) & BamHI & Sall & GST & AT4G I 4400 \\
\hline PTHEII & pUC-19 & MHAL CDS & Kpnl & Bspl|19| & HA-GFP & ATIGII736 \\
\hline PTHEI3 & pETM4I & MHAL CDS & Kpnl & BamHI & MBP- $6 x \mathrm{His}$ & ATIGII736 \\
\hline PTHE23 & pUC-19 & MHAL-N & Kpnl & Bspl|191 & HA-GFP & ATIGII736 \\
\hline PTHE24 & pUC-19 & MHAL-C & Kpnl & Bspl|191 & HA-GFP & ATIGII736 \\
\hline pWZI06 & PETM4I & MHAI (Est-I) & Kpnl & EcoRI & MBP- $6 x \mathrm{His}$ & ATIG62045 \\
\hline PTHE26 & pOO2 & ACD6 (Col-0) & Pstl & Sall & - & AT4G I 4400 \\
\hline PTHE29 & pOO2 & MHAL CDS & Pstl & Sall & - & ATIGII736 \\
\hline PTHE36 & $\mathrm{pOO} 2$ & ACD6 (ACD6-I) & Pstl & Sall & - & AT4GI4400 \\
\hline pWZI23 & pCAMBIA I300-nLuc & MHAI (Est-I) & Gibsor & assembly & $n L U C$ & ATIG62045 \\
\hline pWZI35 & PCAMBIA I300-nLuc & MHAI (Ty-0) & Gibson & assembly & nLUC & ATIG62045 \\
\hline pWZI22 & PCAMBIA I300-nLuc & ACD6 (Est-I) & Gibson & assembly & cLUC & AT4G I 4400 \\
\hline pWZI44 & PCAMBIA I300-cLuc & ACD6 (Col-0) & Gibsor & assembly & cLUC & AT4GI4400 \\
\hline pWZI82 & PCAMBIA I300-nLuc & MHAL CDS & Gibsor & assembly & $n L U C$ & ATIGII736 \\
\hline
\end{tabular}

